University of Redlands

\title{
Developing a Web Application to Identify Industrial Specialization in Southern California
}

A Major Individual Project submitted in partial satisfaction of the requirements

for the degree of Master of Science in Geographic Information Systems

$$
\text { by }
$$

Sara Goose

Fang Ren, Ph.D., Committee Chair

Douglas Flewelling, Ph.D.

August 2011 
Developing a Web Application to Identify Industrial Specialization in Southern California

Copyright () 2011

by

Sara Goose 
The report of Sara Ann Goose is approved.

Douglas Flewelling, Ph.D.

Fang Ren, Ph.D., Committee Chair

August 2011 



\section{Acknowledgements}

I would first like to thank all of my family and friends for their support and encouragement throughout this process. I would also like to thank my daughter Jordan; she is now and has always been my inspiration. To my advisor Dr. Fang Ren, this journey would not have been the same without your dedication and support. To Dr. Doug Flewelling, I have very much enjoyed our conversations. I am most certain however, that I will always need a UML cheat sheet. I would like to recognize Stephen Daugherty for his technical advice and support on this project as well. To Debra Riley, you are the heart and soul of the operation and I have found in you a lifelong friend. Lastly, to Ruben Ortiz for preventing my laptop from melting and for the wonderful conversations we've shared, thank-you. 



\title{
Abstract \\ Developing a Web Application to Identify Industrial Specialization in Southern California
}

by

\author{
Sara Ann Goose
}

Economic and community planning professionals consistently look for ways to measure the strengths and opportunities of their locale. In an effort to restrain from participating in bubble and burst economic cycles, these professionals have turned toward models of economic sustainability. Industry cluster identification has become a popular starting point to develop policies aimed at these long term objectives. The presence of clusters indicates an opportunity to support industries considered to be specialized for a region, through workforce development and building collaborative ventures among public and private enterprises. However, the presence of clusters have traditionally been identified by analyzing data in tabular and spreadsheet form. These methods ignores a fundamental aspect and benefit of using clusters as the basis for development; location. Storing this data in a Geographic Information System (GIS) and presenting the information in a more digestible manner would allow planners to visualize the presence of clusters. This report documents the development of a GIS based web application that gives economic developers the opportunity to identify industry clusters in a new way. 



\section{Table of Contents}

Chapter 1 - Introduction ......................................................................................... 1

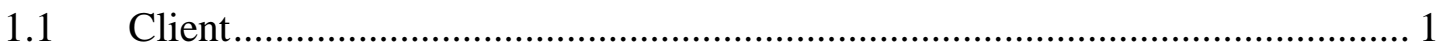

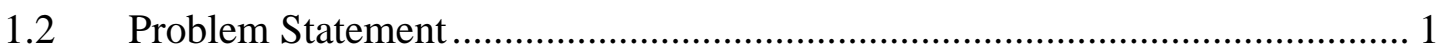

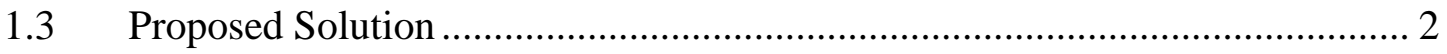

1.3.1 Goals and Objectives …………………………..................................... 2

1.3.2 Scope

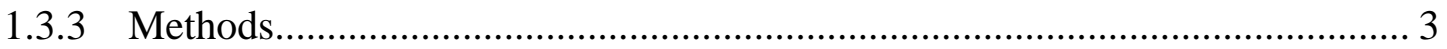

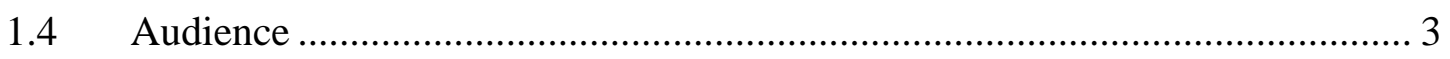

1.5 Overview of the Rest of this Report ................................................................ 4

Chapter 2 - Background and Literature Review ................................................................ 5

2.1 What is an industry cluster? ................................................................... 5

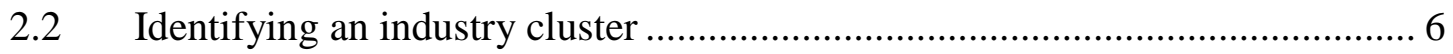

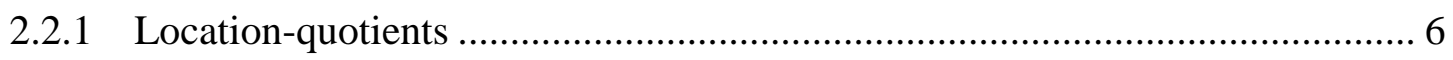

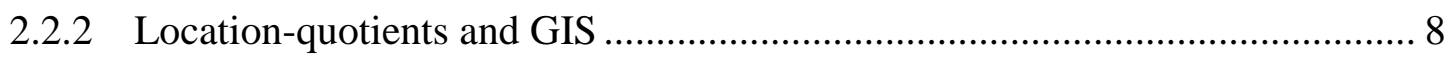

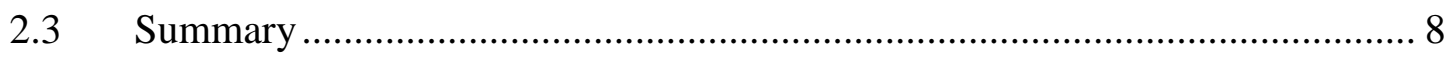

Chapter 3 - Systems Analysis and Design.............................................................................. 9

3.1 Problem Statement ................................................................................... 9

3.2 Requirements Analysis ...................................................................... 9

3.2.1 Functional Requirements .......................................................................... 9

3.2.2 Non-functional Requirements .................................................................... 11

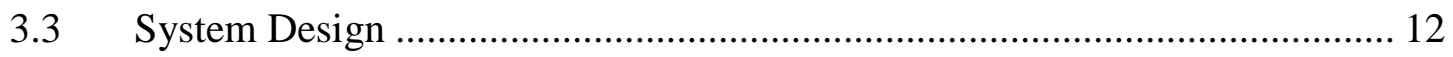

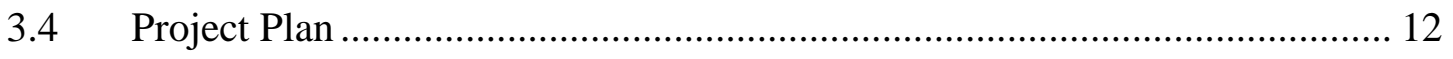


3.5 Summary

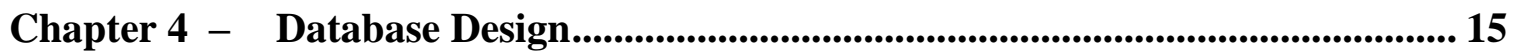

4.1 Conceptual Data Model ...................................................................... 15

4.2 Logical Data Model ................................................................................ 18

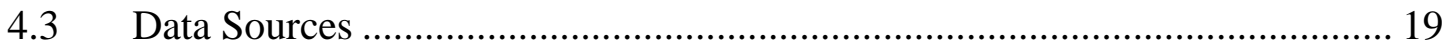

4.4 Data Scrubbing and Loading …………………………………………..... 20

4.4.1 Business Analyst Data ........................................................................ 20

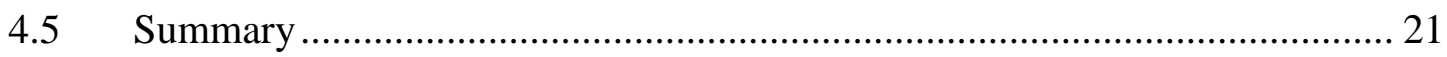

Chapter 5 - Implementation.................................................................................................. 22

5.1 Missing Value Estimation................................................................................ 22

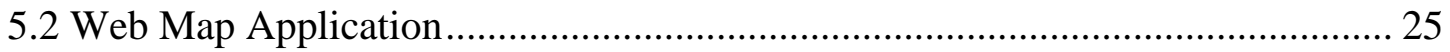

5.2.1 Preparing map documents for publication …………..................................... 25

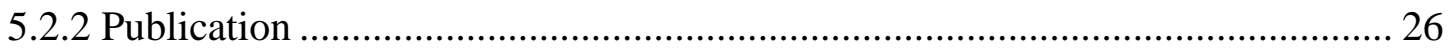

5.2.3 Application Development and Customization ................................................... 29

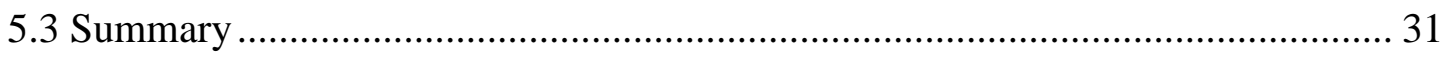

Chapter 6 - Results and Analysis........................................................................... 33

6.1 Analyzing Specialization of an Industry Sub-Sector ...................................... 33

6.2 Analyzing Industry Groups within an Industry Cluster................................... 38

6.3 Summary:

Chapter 7 - Conclusions and Future Work ........................................................................... 45

Works Cited 47

Appendix A. Industry Summary Tables............................................................................ 52 



\section{Table of Figures}

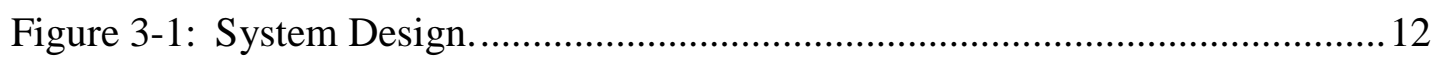

Figure 4-1: Administrative Unit Conceptual Model..............................16

Figure 4-2: Supporting Data Conceptual Model................................17

Figure 4-3: Location Quotient Database Layers.................................18

Figure 4-4: Supporting Database Layers......................................19

Figure 5-1: Combined County Business Patterns Data...........................22

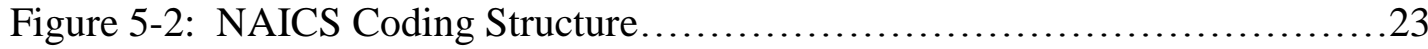

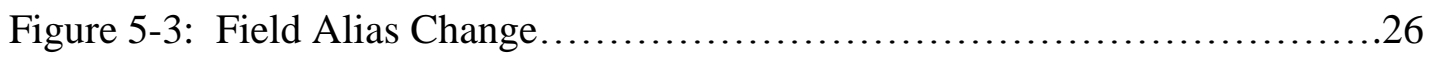

Figure 5-4: LocationQuotients ArcMap Document.............................27

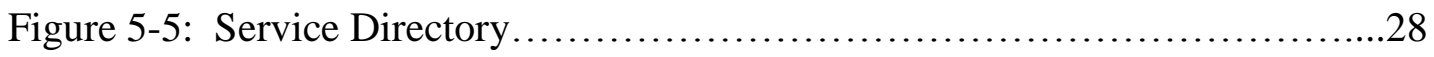

Figure 5-6: Sharing ArcGIS Web Application................................28

Figure 5-7: ArcGIS Chrome Identify Template................................29

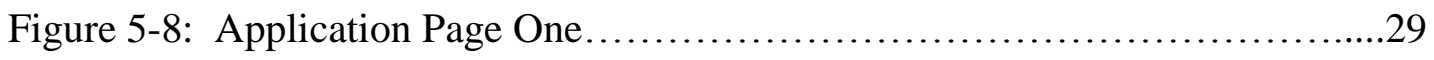

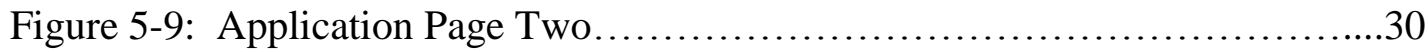

Figure 5-10: ArcGIS Customized Template.......................................31

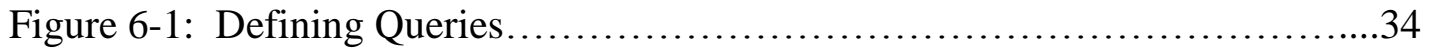

Figure 6-2: County/State Employment, NAICS-622, Hospitals.....................34

Figure 6-3: County/Nation Employment, NAICS-622, Hospitals....................35

Figure 6-4: County/State Establishment, NAICS-622, Hospitals.....................35

Figure 6-5: County/Nation Establishment, NAICS-622, Hospitals....................36

Figure 6-6: Population Distribution by Zip Code..................................37

Figure 6-7: Employment by Zip Code, Healthcare Industry ......................38 
Figure 6-8: County/State Employment, NAICS-6221, General Medical and Surgical Hospitals................................................ 39

Figure 6-9: County/Nation Employment, NAICS-6221, General Medical and Surgical Hospitals.................................................39

Figure 6-10: County/State Employment, NAICS-6222, Psychiatric and Substance Abuse Hospitals

Figure 6-11: County/Nation Employment, NAICS-6222, Psychiatric and Substance Abuse Hospitals...

Figure 6-12: County/Nation Employment, NAICS-6222, Identify................41

Figure 6-13: County/State Employment, NAICS-6223, Specialty Hospitals........42

Figure 6-14: County/Nation Employment, NAICS-6223, Specialty Hospitals.......42

Figure 6-15: Model to Select Potential Educational Facilities....................43

Figure 6-16: Selected Colleges..........................................44 


\section{List of Tables}

Table 3-1: Functional Requirements for LQ Calculation........................... 10

Table 3-2: Functional Requirements for Web Application............................ 10

Table 3-3: Non-Functional Requirements for Industry Cluster Identification

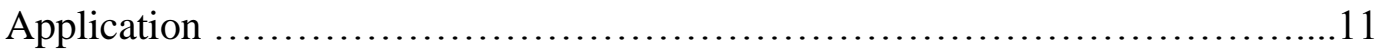

Table 5-1: Flagged Data Example..............................................23

Table 5-2: Summary of Data Estimation Method................................24

Table A-1: Top Five Location Quotient Values for Each County and Variable..........52

Table A-2: All Specialized Industries by County ..............................57

Table A-3: Application Code..............................................99 



\section{List of Acronyms and Definitions}

$\begin{array}{ll}\text { GIS } & \text { Geographic information system } \\ \text { LQ } & \text { Location quotient } \\ \text { NAICS } & \text { North American Industrial Classification System } \\ \text { CBP } & \text { County Business Patterns } \\ \text { BLS } & \text { Bureau of Labor Statistics }\end{array}$





\section{Chapter 1 - Introduction}

The way that economic strength is measured and evaluated can result in dramatic changes to public policy decisions. There are many common indictors used by economic development professionals when making these assessments. For example, employment statistics, workforce characteristics, and per capita income are commonly used variables in economic analysis. Recently, the identification of industry clusters as a measurement of economic strength has become popular. The presence of an industry cluster indicates that an area has a particular specialization in that industry. For policy makers, this provides an opportunity to support specialized industries through workforce and other development programs.

The use of location quotients as a means to identify clusters has become standard. However, the viability of this type of economic analysis has been limited by the scope and use of tables for assessment. Using a GIS as the format for analysis would give economic policy makers a spatial view of data conventionally processed as tables and charts. The following document will review industry cluster identification as an economic model through prior research, the methods used to identify industry clusters with emphasis on location quotients, and how a GIS can be used to aggregate economic data into a spatial format that can serve the purposes of analysis in a more productive manner. In particular, this project focuses on the development of a GIS web application to display regional clusters.

\subsection{Client}

The client for this project was Jon Harrison of Esri in Redlands, California. He is a project manager for Local Government Solutions at Esri and also serves as a council member for the City of Redlands. Mr. Harrison is involved in a number of local economic development and environmental conservation committees; including the Southern California Association of Government, the League of California Cities, and the Environmental Quality Policy Committee. Mr. Harrison is interested in using GIS as a platform for developing an industry cluster-based economic sustainability model.

\subsection{Problem Statement}

Economic developers have recently turned to cluster analysis as a model for economic sustainability. The benefit of identifying clusters lies in recognizing areas of economic strengths and opportunities for the promotion of policies that make the best use of limited resources. There were three problems addressed by this project. The first involves how location quotients (LQ) are used to measure the presence of industry clusters within a region. LQ values are typically calculated by comparing employment per industry at the county level to industry employment at the national level. However, there are other measures of economic activity that could be used in this calculation. Second, cluster studies have commonly focused on only one or several industries at a time. This limits 
the ability of economic planners to gauge the performance of a wider range of industries. The North American Industrial Classification System (NAICS) "is the standard used by Federal statistical agencies in classifying business establishments for the purpose of collecting, analyzing, and publishing statistical data related to the U.S. business economy" (U.S. Census, 2011a). The NAICS organizes industries by using a series of numbered codes. The codes range from a two digit industry Sector down to a six digit detailed industry description. The third problem addressed by this project deal with format and presentation of data associated with identifying clusters and evaluating information useful to economic development professionals. Data on industry employment is most often viewed and evaluated in tabular form, a spreadsheet or database program. This method excludes the possibility of visually identifying the spatial relationships among the administrative units for which the data are collected. Additionally, where GIS has been used for mapping clusters, the resulting product has been static or printed maps.

\subsection{Proposed Solution}

The proposed solution was to create a general use application to identify industry clusters. To accomplish this task, the variable and comparison level used in calculating LQs was expanded first. Then, the number of industries included in the application was extended to all NAICS codes through the fourth digit. Third, LQ values and industry descriptions were displayed in a Web application as a choropleth map. The map would identify counties that were considered non-specialized, emerging, or having a low or high specialization in an industry. The presentation of the LQ values in this fashion makes it easier to evaluate an area in comparison with its neighbors. Finally, important data used in cluster analysis were included as well with the intention of building analytical tools into the application over time for these layers.

\subsubsection{Goals and Objectives}

The goal of this project was to develop a demonstrative Web application for industry cluster identification, as well as, to provide the client with a geodatabase that could be built upon over time with the intention of eventually integrating different layers into the Web application for a complete cluster analysis platform. There were several objectives outlined for this project. One was to calculate LQ values for all NAICS industries through the industry group definition. This included two different levels of comparison and two variables. Second was to transfer LQ data from spreadsheet form to a geodatabase. Third was to make available layers that provided more local data on industry employment, educational attainment, and the locations of educational facilities. The last objective was to develop a Web application using the ArcGIS Javascript API to make the presentation of data more meaningful.

\subsubsection{Scope}

The original scope of the project included all 58 California counties. However, the scope of the project was reduced to five counties: Los Angeles, Orange, Riverside, San Bernardino, and San Diego. The reduction in scope came about as more was learned about the data suppression issues associated with the primary data source. The 
employment data from the CBP datasets contains a large amount of flagged data cells that must be estimated.

Several layers were incorporated into the final geodatabase for the purpose of building analytical functions into the Web application over time. These layers were included as supporting data for industry cluster analysis and recommended in cluster literature. Mainly, this information included more localized information about industry employment, workforce characteristics, and locations of training and educational facilities.

\subsubsection{Methods}

Prior to planning the development of a Web application for cluster identification, research was conducted to gain an understanding of the use of industry clusters as a means for economic development, in order to evaluate the utility of the project. Research was also conducted to identify the methods used in identifying clusters. The use of the location quotient was found to be the most prevalent way to identify clusters and was selected for use in this project.

In line with researched cluster studies that have utilized the location quotient, the primary data source for these calculations was the 2008 County Business Patterns. The data were retrieved and downloaded from the American Fact Finder website as Excel files. These data included employment and establishment data for the selected California counties, the state of California, and for the US. Once compiled into a single spreadsheet, a data estimation method was developed to overcome data suppression issues associated with the employment counts. ArcGIS Business Analyst provided the remaining layers included in the geodatabase.

ArcGIS 10 (ArcInfo license) was selected as the primary software for storage and display. The client had access to Arc suite of software products and could maintain the associated geodatabase on a single desktop. Also, ArcSDE and ArcGIS were used to develop and publish the Web application.

Once the LQ values were calculated, spatial joins were performed to create 16 county-based layers containing all values. These feature layers were stored in ArcSDE and published through ArcGIS Server. The remaining feature classes were also published separately. The ArcGIS JavaScript API was used to create the Web application functions.. Additionally, summary tables of LQ values were created and included in the Web application. Finally, a user scenario was developed to demonstrate how the Web application should be used by community planners.

\subsection{Audience}

The audience for this report are economic and community planners that are interested in industry clusters as a measure of economic strength and opportunity. It is also intended for those who may have very little experience with GIS. Interested parties may include economic and community planners as well a public policy makers. Some terminology used in this report may be technical in nature and not understood by laypersons. However, considerations were made in explaining unfamiliar language. 


\subsection{Overview of the Rest of this Report}

There are six additional chapters included in the remainder of this report. Chapter Two covers a literature review that explores industry clusters, methods used to identify cluster, and how these methods have been used in GIS analysis. An overview of the system design, including functional and non-functional requirements, is discussed in Chapter Three. Chapter Four concerns the database design, as well as data scrubbing and loading methods. This chapter also explains the data estimation method used in determining employment numbers for the LQ values. The implementation of the project is reviewed in Chapter Five, and includes steps taken to prepare the layers for publication and web application development. A user scenario and results are discussed in Chapter Six. Conclusions and future work are discussed in Chapter Seven. 


\section{Chapter 2 - Background and Literature Review}

Economic development policies are moving away from the concept that prosperity is linked solely to the production and consumption of goods. Given the lessons imbedded in the recent recession, policy makers and industry leaders are now looking toward more sustainable economic strategies rooted in applied knowledge and innovation. A growing interest in cluster analysis has provided a new paradigm for looking at public policy and local economies in a more holistic manner. A cluster analysis involves identifying the economic strengths and weaknesses of a region based on a combination of quantitative and qualitative methods. In essence, it can be considered "a general mode of inquiry" designed to address "particular policy concerns" (vom Hofe, 2006, p. 20).

Traditionally, local industry investment has been driven in part by access to inexpensive labor, low tax rates, and other variables. An applied knowledge economy requires looking at a different set of factors in determining how public policy decisions can support the sustainability of industry. Porter (1998) describes cluster analysis as "a new way of thinking about location, challenging much of the conventional wisdom about how companies should be configured, how institutions such as universities can contribute to competitive success, and how governments can promote economic development and prosperity" (p.78). For example, regional and local planners might consider the educational attainment of local residents, unemployment data, and access to research facilities when making decisions regarding the allocation of resources. Access to major transportation routes, community and entertainment centers, or public parks are also factors that can affect where industry leaders invest. The following sections will review the definition of a cluster, what criteria are used to identify industry clusters, and how geographic information systems play a role in analysis and visualization.

\subsection{What is an industry cluster?}

Porter (2000) defines the term "cluster" as " geographic concentrations of interconnected companies, specialized suppliers, service providers, firms in related industries, and associated institutions (e.g., universities, standards agencies, trade associations) in a particular field that compete but also cooperate" (p.16).

The cluster approach to developing sustainable economic policy requires more than identifying where individual and interconnected businesses are located. The underlying concept of a cluster approach for economic development is that companies gain a competitive advantage by accessing local resources like infrastructure, an educated workforce, nearby educational and research facilities, and lateral innovation cooperatives. In other words, industry leaders are more likely to view particular locations as favorable to investment if there is an established reputation for an industry. Malmberg (1996) describes two convergent observations concerning the link between location and industry success:

The first is that economic, entrepreneurial and technological activities tend to agglomerate at certain places, leading to patterns of national and regional specialization. The second is that the performance and development of a firm to a 
considerable extent seems to be determined by the conditions that prevail in its environment, and that the conditions in the immediate proximity - in the local milieu - seem to be particularly important. (p. 85)

A region where a particular industry specialization has been identified is an indication that the industry has access to the supporting structure that allows it to sustain and prosper in that region. For those involved in economic development, the benefits of identifying industry specialization for investment include taking advantage of the "economic efficiencies that reduce costs (of information, of specialized inputs and infrastructure, and of skilled labor) for firms in the cluster, reduced risk to investment in start-up companies in the cluster, and the generation of visibility and identity for a region" (Kelton, 2006, p.4).

A distinction should be made here between a cluster analysis based on the geographic dispersion of related businesses and industrial clusters that focus on regional specialization. These two distinctions are necessary because they utilize different sets of data. For a business cluster analysis, proprietary information regarding how distinct enterprises and supporting organizations are related is required. A business cluster analysis is based on an understanding of how individual businesses within an industry are organized in a value chain. The spatial distribution of businesses are also considered. This method is qualitative in nature and may draw upon the use of surveys and expert opinion (Nolan, 2006; Feser, 2001). However, analysts often begin by using quantitative methods to identify industry cluster or regions that are considered specialized in an industry. This initial investigation is typically based on public data sources like the Census Bureau's County Business Patterns (CBP), the Bureau of Labor Statistics (BLS) and the Quarterly Census of Employment and Wages (QCEW). The following section will discuss the ways in which industry clusters are identified.

\subsection{Identifying an industry cluster}

Quantitative methods of identifying industry clusters include shift-share analysis, inputoutput tables, and location quotients (Nolan, 2006; Nacker, 2004; Frizado 2007). One method is not preferred over others and some of these methods are used in combination. Ultimately, the method of choice is dependent on the question being asked. Location quotients are used to identify the presence of clusters by industrial specialization. Inputoutput models show the purchasing patterns between businesses. And a shift-share analysis looks at changes in employment based on national, regional, and industry dependent factors. The remaining sections will look at location-quotients in more detail as well as its use in GIS applications.

\subsubsection{Location-quotients}

Location quotients (LQ) are used frequently in the identification of industry specialization. Data for industry employment and number of establishments are publicly available and provide the information necessary to calculate these values. Fleming (2008) used LQ values derived from the Census Bureau's CBP data to identify transportation and warehousing specialization in San Bernardino and Riverside counties 
(California). Bose (2002) also used the CBP data to calculate LQ values for identifying 'Internal Combustion Engines' clusters in Illinois. Kelton (2006) made use of the same data set and method to identify several industry clusters across the US.

A location-quotient measures the industry strength of a given study area against the industry strength of a given reference area. A common approach is to compare employment at the county level (study area) against employment at the national level (reference area) for a particular industry. However, establishment or other economic indicators may be used (Nolan, 2006). The following equation represents the standard method for calculating location-quotients:

$$
L Q=\frac{n_{1} / n}{N_{1} / N}
$$

Where: $n_{1}=$ industry employment for the study area

$n=$ total employment for the study area

$N_{1}=$ industry employment for the reference area

$N=$ total employment for the reference area

According to the Bureau of Labor Statistics website (http://www.bls.gov/help/def/lq.htm, 2011), "if an LQ is equal to 1, then the industry has the same share of its area employment as it does in the reference area. An LQ greater than 1 indicates an industry with a greater share of the local area employment than is the case in the reference area." The assumption is that higher LQ values indicate an export industry due to specialization. Nacker (2004) designates the interpretation of LQ values as follows:

\section{Location Quotient}

$$
\begin{gathered}
\leq 0.75 \\
0.76 \leq \mathrm{LQ} \leq 1.24 \\
\geq 1.25
\end{gathered}
$$

\section{Export/Import Status}

Import Industry

Self-Sufficient Industry

Export Industry

The CBP datasets are commonly used for LQ analysis because it provides the number of employees and establishments for a given industry based on the North American Industrial Classification System (NAICS). Some of the employment data however, has been suppressed to preserve confidentiality. In an effort to overcome this problem, researchers have had to adjust their methods for determining location-quotient values. In a comprehensive study on industry clusters, the research team from Indiana and Purdue Universities (Unlocking Rural Competitiveness: The Role of Regional Clusters, 2007, p.20) "revised cluster definitions to use three-digit NAICS sectors wherever possible for the nationwide county analysis, minimizing reliance upon more- 
detailed NAICS levels as much as possible". Bose (2002) used an estimation method based on mid-point values for both employment and establishment data in his study on the' Internal Combustion Engines' industry for Illinois. Once LQ values are derived, GIS technology then becomes a significant medium for further analysis and visualization.

\subsubsection{Location-quotients and GIS}

Efforts to identify regions of industrial specialization using LQ values and GIS have produced a range of analytical and visual techniques. Some studies have focused on specific industries while others are more comprehensive in nature. Industry specific analyses have used GIS to map business clusters in relation to supporting infrastructure or institutions. For example, Bose (2002) calculated LQ values in a database and performed a query to select out the values for supplier and market industries based on particular NAICS codes. This selected data was then joined to a shapefile representing one major city within each county in Illinois. A GIS was then used to visualize major cities with an industry specialization in relation to major transportation routes and technology centers. Sarkar (2009) performed a similar analysis for the transportation and warehousing industry at the zip code level for southern California.

Spatial statistics offer an alternate analysis method for exploiting location quotient values in a meaningful way. Frizado (2007) calculated LQ values for the 'transportation equipment' industry at the county level for the U.S. He then used Moran's I and GetisOrd Gi* analysis to delineate cluster regions across areal boundaries by comparing likesized counties as well as dissimilar county groups. The study yielded similar results regardless of the choice of spatial weights matrix. Reid (2007) also used LQ values and measures of local spatial autocorrelation (Getis-Ord Gi*) to identify regions of specialization in Ohio. Regions that showed LQ values greater than one in combination with a high $\mathrm{G}^{*}$ values were defined as potential cluster regions.

Several techniques have been used to visualize regions of specialization. For example, county level data are often represented by polygon features in a choropleth display. Alternately, Nolan (2006) used point and graduated-symbols to display LQ values for specified industries across the US using county centroids.

\subsection{Summary}

This chapter examined what defines an industry cluster as well as methods used to identify an industry cluster. Particular emphasis was placed on the location quotient as a common method for identification. A literature review of location quotients used in GIS analysis closes this chapter. The following chapter discusses the systems analysis, including functional and non-functional requirements. 


\section{Chapter 3 - Systems Analysis and Design}

The goal of this project was to develop a general application to enable economic and community planners a way to identify industry clusters. Its intended use as a platform for economic development professionals was emphasized by the client and was the primary consideration during development. This chapter briefly outlines the problem statement, followed by a more detailed discussion of both functional and non-functional requirements. Both the initial project plan and changes made as the project progressed are examined.

\subsection{Problem Statement}

Cluster analysis has become an influential platform used by economic developers and planners to assess local industry specialization. Location-quotients (LQ) are commonly used to identify these industries, particularly at the county level. However, the current approach to examining the LQ values of various industries is through tabular data. To assist economic professionals, the client needed a tool that can allow users to visualize the spatial distribution of LQ values of various industries.

\subsection{Requirements Analysis}

The primary deliverables for this project included: calculating location-quotients based on four levels of comparison for all NAICS codes through the Industry Group classification for display in a Web application. Additionally, users should be able to assess industry employment by zip code and educational attainment by census tract delineations. A requirements analysis was conducted to ensure that the project would meet the client's needs. This section addresses both functional and non-functional requirements.

\subsubsection{Functional Requirements}

Table 3-1 summarizes the functional requirement for the location-quotient (LQ) calculations. These requirements included the methods for data acquisition and formatting to allow for a table join to the respective spatial component. County Business Patterns (CBP) data is compiled every five years. Based on the assumption that this platform will be used to track industrial specialization over time, it is necessary for the user to duplicate the process when new datasets are available. 
Table 3-1 Functional Requirements for LQ calculation

\begin{tabular}{|l|l|}
\hline Requirement & Description \\
\hline $\begin{array}{l}\text { Select County Business Patterns data from } \\
\text { American Fact Finder website and } \\
\text { download. }\end{array}$ & $\begin{array}{l}\text { To provide users with an expanded level of } \\
\text { comparison for analysis both employment } \\
\text { and establishment data were collected. }\end{array}$ \\
\hline Select and merge data for the study area. & $\begin{array}{l}\text { To aid in LQ calculations, employment and } \\
\text { establishment data for all NAICS codes } \\
\text { through the fourth digit were merged into a } \\
\text { single excel table. }\end{array}$ \\
\hline $\begin{array}{l}\text { Develop method to overcome data } \\
\text { suppression issues for employment. }\end{array}$ & $\begin{array}{l}\text { To allow users to duplicate estimation for } \\
\text { future data sets. }\end{array}$ \\
\hline
\end{tabular}

Table 3-2 identifies the functional requirements for the Web application using the ArcGIS API for JavaScript. These requirements were determined based on potential use cases. The application initiates with options that allow users to choose between a level of comparison (county/state or county/nation) and a comparison variable (employment or establishments) using radio buttons. Additionally, the user must select a NAICS code to display. To allow for a more localized analysis once industry specialization has been identified, the user will be able to scale down to the zip code level to inspect employment by industry data. Also, level of educational attainment for local communities will be accessible at census tract delineations, as well as the location of educational and training institutions.

Table 3-2 Functional Requirements for Web Application

\begin{tabular}{|l|l|}
\hline Requirement & Description \\
\hline $\begin{array}{l}\text { Select options to display location-quotient } \\
\text { values. }\end{array}$ & $\begin{array}{l}\text { To allow visualization of LQ values for } \\
\text { study area. }\end{array}$ \\
\hline Select zip-code or census tract. & $\begin{array}{l}\text { To allow users to assess more localized } \\
\text { workforce characteristics. }\end{array}$ \\
\hline Identify local educational facilities & $\begin{array}{l}\text { To allow users to identify community } \\
\text { access to educational and training facilities. }\end{array}$ \\
\hline Display attributes values in a list. & To provide an easy to read format. \\
\hline
\end{tabular}




\subsubsection{Non-functional Requirements}

The non-functional requirements for this project are comprised of technical, operational, and transitional considerations based on potential use cases. ArcGIS Desktop 10 supported the minimal technical requirements for compiling data for the application and ArcGIS Server 10 was used to publish the resulting map document. Microsoft Visual Studio 10 was used to compile and customize the web application. Table 3-3 summarizes these requirements.

Table 3-3 Non-Functional Requirements for Industry Cluster Identification Application

\begin{tabular}{|c|c|}
\hline Requirement & Description \\
\hline \multicolumn{2}{|l|}{ Technical } \\
\hline Microsoft Excel 10 & $\begin{array}{l}\text { County Business Patterns data is } \\
\text { downloadable in excel format. Location- } \\
\text { quotients were calculated and formatted for } \\
\text { use in ArcMap with Excel. }\end{array}$ \\
\hline ArcGIS Desktop 10 & $\begin{array}{l}\text { Industry cluster data was compiled and } \\
\text { displayed using ArcGIS Desktop } 10 .\end{array}$ \\
\hline ArcGIS Server 10 & $\begin{array}{l}\text { The web application was published using } \\
\text { ArcGIS Server } 10 \text {. }\end{array}$ \\
\hline Microsoft Visual Studio 10 & $\begin{array}{l}\text { Microsoft Visual Studio was used to } \\
\text { compile and customize the web application }\end{array}$ \\
\hline \multicolumn{2}{|l|}{ Operational } \\
\hline $\begin{array}{l}\text { Comprehensive display of industry } \\
\text { specialization for study area. }\end{array}$ & $\begin{array}{l}\text { Location-quotients were calculated for all } \\
\text { available NAICS codes through the fourth } \\
\text { digit and for four levels of comparison. }\end{array}$ \\
\hline $\begin{array}{l}\text { Viable platform for analyzing regions of } \\
\text { economic strengths and opportunities. }\end{array}$ & $\begin{array}{l}\text { In addition to identifying industry } \\
\text { specialization, workforce and demographic } \\
\text { data are included for more local } \\
\text { assessment. }\end{array}$ \\
\hline \multicolumn{2}{|l|}{ Transitional } \\
\hline Demonstration & $\begin{array}{l}\text { A demonstration on how to utilize the } \mathrm{Web} \\
\text { application. }\end{array}$ \\
\hline
\end{tabular}

In addition to the technical requirements, operational and transitional requirements were determined by way of potential use cases. For example, it is important that the user has clear options for selecting a level of comparison from the four given. Also, the options for display include selecting a single county or comparing different counties based on the user's selection of a NAICS code. Furthermore, as a platform for cluster analysis, the user should be able to scale down from the county level to examine local employment data. A demonstration of how to best utilize the components and features of the application was required and provided for the client. 


\subsection{System Design}

The system design was determined based on the client's request and the requirements analysis. The geodatabase includes four fundamental layers of information. The first is a composite of sixteen layers consisting of identical spatial boundaries (county) representing the four comparison types of LQ values. The comparison types include: county/state employment, county/nation employment, county/state establishment, and county/nation establishment. With the various levels of comparisons of LQ, economic planners and specialists can perform a series of analyses for the full spectrum of industry sectors and supporting industries.

The remaining three layers include: industry employment layer, educational attainment layer, and educational institutions layer. Interested parties can use the Web application platform to narrow down areas of potential economic development based on the given data. The intention was to provide a tool for policy makers to assess industry strengths and weaknesses and to evaluate local trends in employment and educational opportunities. Figure 3-1 shows the system design as four major components.

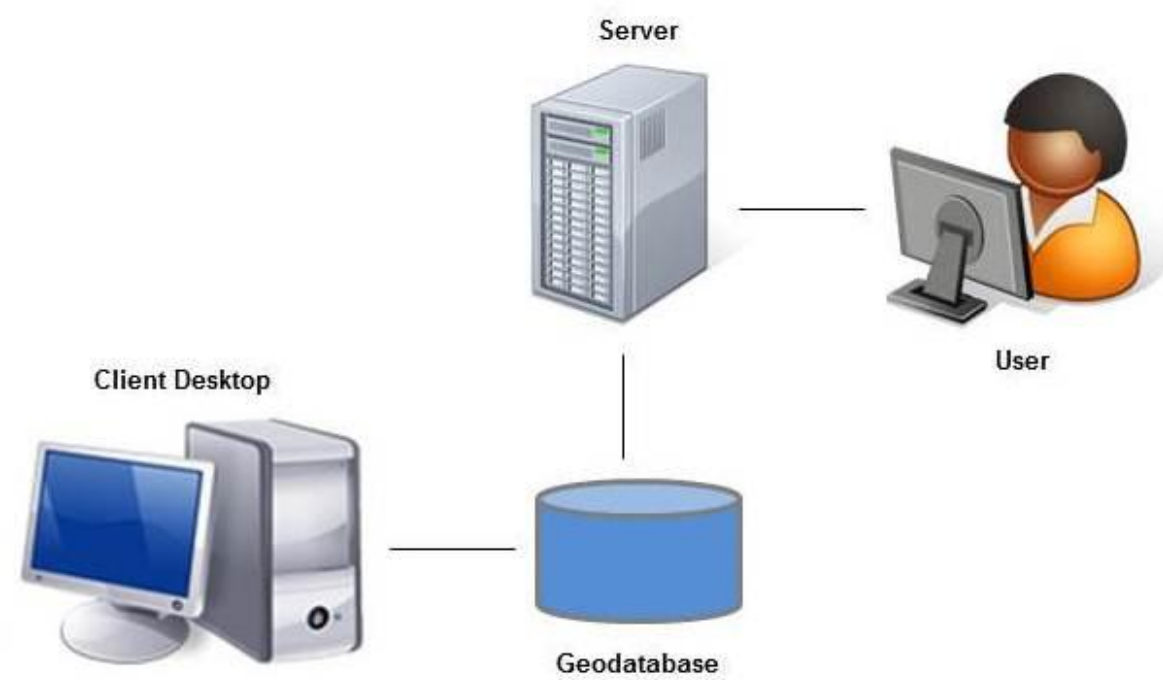

Figure 3-1: System Design

The geodatabase can be accessed and maintained on the client's desktop unit. Additionally, the client's organization is the proprietor of the ArcGIS suite of products including ArcGIS server. This ensured access to the technical requirements needed to maintain the system and update as necessary.

\subsection{Project Plan}

To complete the project in the given time frame and to fulfill the major components of the client's proposal, the project plan initially included five phases of development:

- Phase 1: Requirements Analysis

A review of cluster literature was conducted to understand the use of location-quotients's in identifying industry specialization. The use of LQ data as the basis for GIS analysis 
was also identified in several studies, however Web applications were not found to be available. The primary display of LQ values using GIS for cluster analysis was given as static maps and tabular data.

- Phase 2: Data Acquisition

Phase two required data acquisition from the Census Bureau's County Business Pattrens (CBP) datasets as well as relevant information acquired from Business Analyst datasets.

- Phase 3: LQ Calculation and Spatial Joins

Industry employment and establishment data were downloaded in Excel format for all California counties. The resulting LQ calculations were based on four levels of comparison and then spatially joined to county shapefiles in ArcMap.

- Phase 4: Geodatabase Development

In an effort to include elements recommended by the cluster analysis literature, several data layers were added to provide localized information on employment and education.

- Phase 5: Web-application Development

The Web application was developed using the Javascript API. The primary function is an interface that allows users to select an industry and comparison level to display countylevel LQ values as a class-breaks rendered graphic.

Several adjustments were made throughout the course of implementing the project. Originally, the project was intended to cover a much larger geographic area. However, once it was determined that data suppression issues would present significant difficulties for calculating the necessary values, the study area was reduced from including all fifty-eight California counties to five. An estimation methodology was utilized to overcome the problem with data suppression Also, due to limitations on table joins in ArcMap, the LQ layers were increased from an intended four layers to sixteen. Each of the initial four layers would have included the full spectrum of NAICS codes (and the associated LQ values) for each of the comparison levels. The resulting sixteen layers were divided by comparison level and by NAICS code. Finally, the ArcGIS API for Flex was initially targeted as the development framework for the application, was then changed to the Javascript API.

\subsection{Summary}

The initial project plan and system design were based on the requirements analysis. This chapter focused on both functional and non-functional requirements for project completion. Considerations for the analysis included technical, operational, and transitional requirements. The development of this framework was crucial to the implementation process. As project development progressed, modifications to the initial plan were necessary. Several of these changes were discussed here. 



\section{Chapter 4 - Database Design}

The database design for this project included four major components: the conceptual design, the logical design, data collection, and data preparation. First, the conceptual models presented here show the associated entities of the project. Derived from the conceptual model is the logical data model. Next, the data sources used in this project are discussed. Finally, the methods used to prepare and load the data in the geodatabase are introduced.

\subsection{Conceptual Data Model}

An industry cluster analysis often involves identifying regions of specialization and examining factors that support continued specialization within a region. Supporting factors may include access to transportation and research or training facilities. The initial analysis is highly dependent on pre-defined administrative units because most of the publically available data used in cluster identification (specifically the calculation of location quotients) are collected and organized based on these administrative units. Industry groupings used in cluster studies are based on a hierarchical coding system under the North American Industrial Classification System (NAICS). This section presents two conceptual models for the design of cluster related data. A conceptual model is a generalization of real world relationships and assists both designers and endusers of the system, as well as aiding in the development of the logical design (Worboys, p. 69, 1997). The conceptual models presented here provide the structure of related entities involved in this project. The first conceptual model describes the relationship among the selected administrative units as well as their relation to industries (Figure 4-1). 


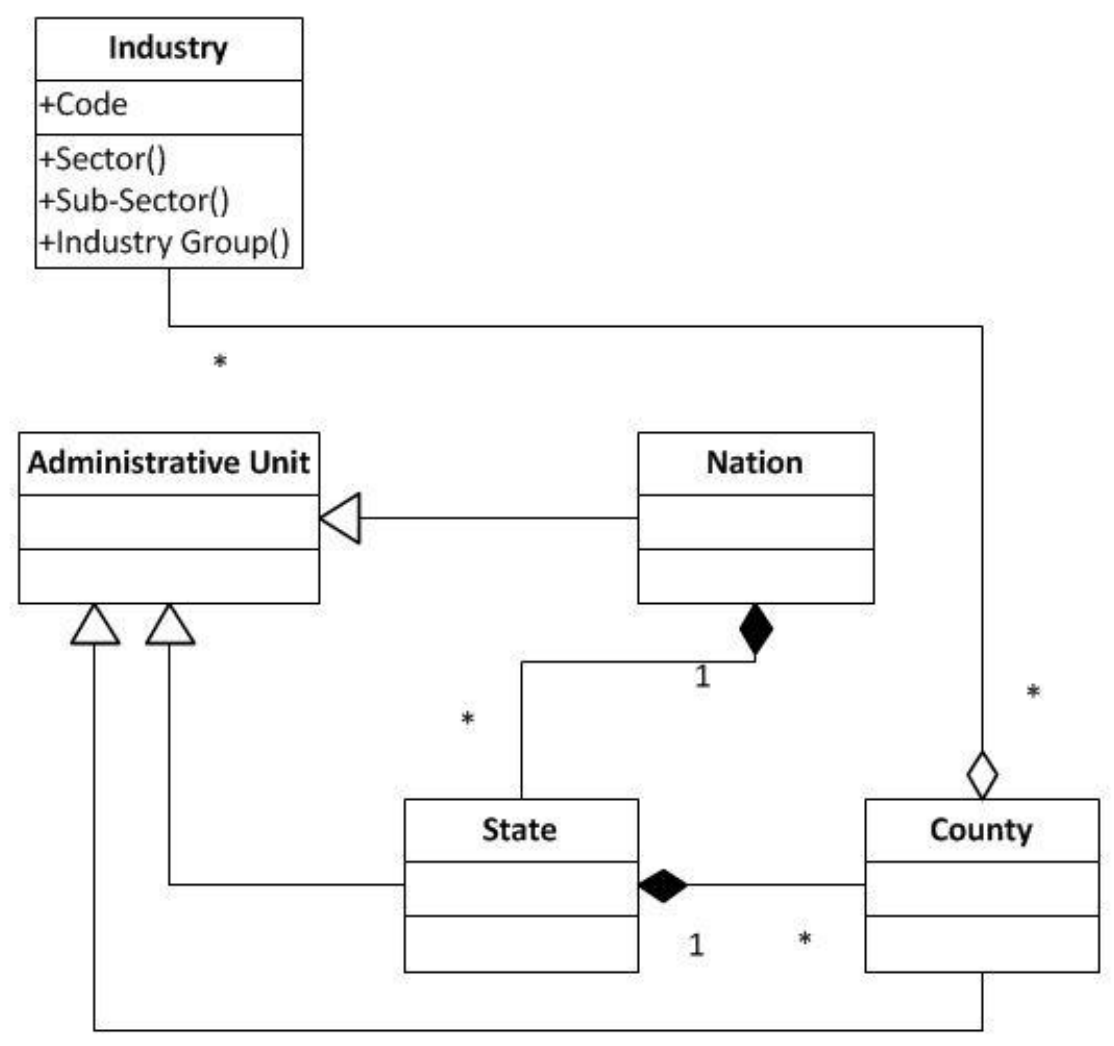

Figure 4-1: Administrative Unit Conceptual Model

The industry class provides the basis for the Industry Specialization Identification Web application. The Industry class is applicable to all administrative units and represents the hierarchical coding structure of the NAICS. Employment and establishment data for industry types are grouped by this classification system. The attributes of the industry class include sector, sub-sector, and industry group. Each industry is identified by a two, three, or four digit code respectively. The sector is the most generalized of the classification schemes. The sub-sector, or three-digit code provides a more detailed industry function within the sector and this process is continued with the industry group. The Administrative Units class contains three classes: nation, state, and county. The state and county classes show a one-to-many relationship.

The second conceptual model represents important entities used in cluster analysis (Figure 4-2). Zip code, census tract, and educational facilities classes are included in the second conceptual model. 


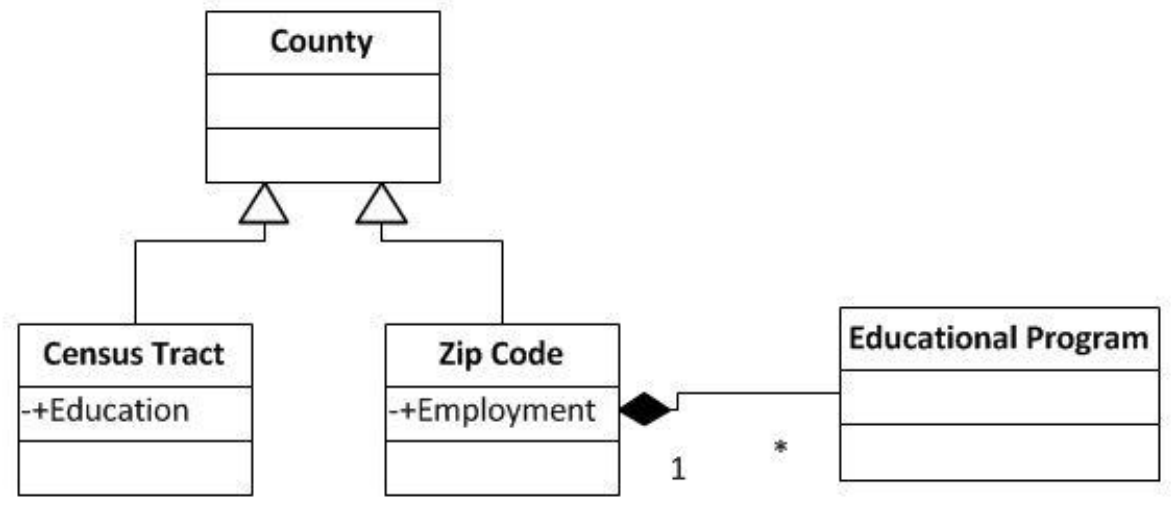

\section{Figure 4-2: Supporting Data Conceptual Model}

The Zip Code and Census Tract classes carry the attributes of employment and education, respectively. These classes are governed by the way the attribute data is collected and are not unique to cluster evaluation. However, these entities do represent smaller units of geographic space and may have important policy implications. For example, the Zip Code class's attribute data gives interested parties a more localized view of distinguishable industry employment and can answer the degree to which the entity participates in a cluster. The Census Tract class provides information important to economic planners and policy makers in terms of evaluating local workforce characteristics. The education attribute constitutes the educational attainment of a local workforce and can give policy makers insight as to how a specialized industry can be sustained in the future.

Access to educational facilities and publicly funded educational programs also affect the long-term ability for knowledge- based industries to draw upon a local workforce. As the economy shifts further away from the manufacturing of goods to one that is knowledge and service based, particular importance will be placed on local access to higher education. This is because "college and graduate degree attainment ties in with occupation. The assumption made here is that significant levels of correlation exist between knowledge, innovation and educational attainment" (Galloway, 2008, p.5). It is important to policy makers and businesses alike to consider the capacity of a labor pool to meet the future needs of an industry. Limited resources can then be focused more directly to support or create educational and training programs designed to meet the needs of industry clusters.

The conceptual models presented here demonstrate the associations among the major entities used for visualizing industry specialization and conducting cluster analysis. For community planners, the ability to shape public policy and support programs that sustain recognized industry clusters, ensure long term economic viability. These professionals also recognize that all industries are dependent on particular workforce characteristics. A knowledge based industry for example, is dependent on a highly educated and trained 
labor supply. Policy makers can have a significant impact on the type of funding needed to support higher education as well as access to learning facilities. The Census Tract and Educational Facilities entities symbolize this information. The following section will describe how these conceptual models were translated into the logical models.

\subsection{Logical Data Model}

A logical data model provides the basis for the physical implementation of the system and is described here in two parts. All feature classes portrayed here are stored in an ArcGIS file geodatabase. First, the Location Quotients (LQ) polygon feature classes are shown grouped together (Figure 4-3). This is because they contain the same data structure and are spatially coincident. These polygon feature classes represent the selected southern California counties: Los Angeles, Orange, San Bernardino, Riverside, and San Diego. Four levels of LQ comparison were generated for these feature classes: County/State Employment, County/Nation Employment, County/State Establishment, and County/Nation Establishment. The industry code attributes are selected by the user for display in the Web application.

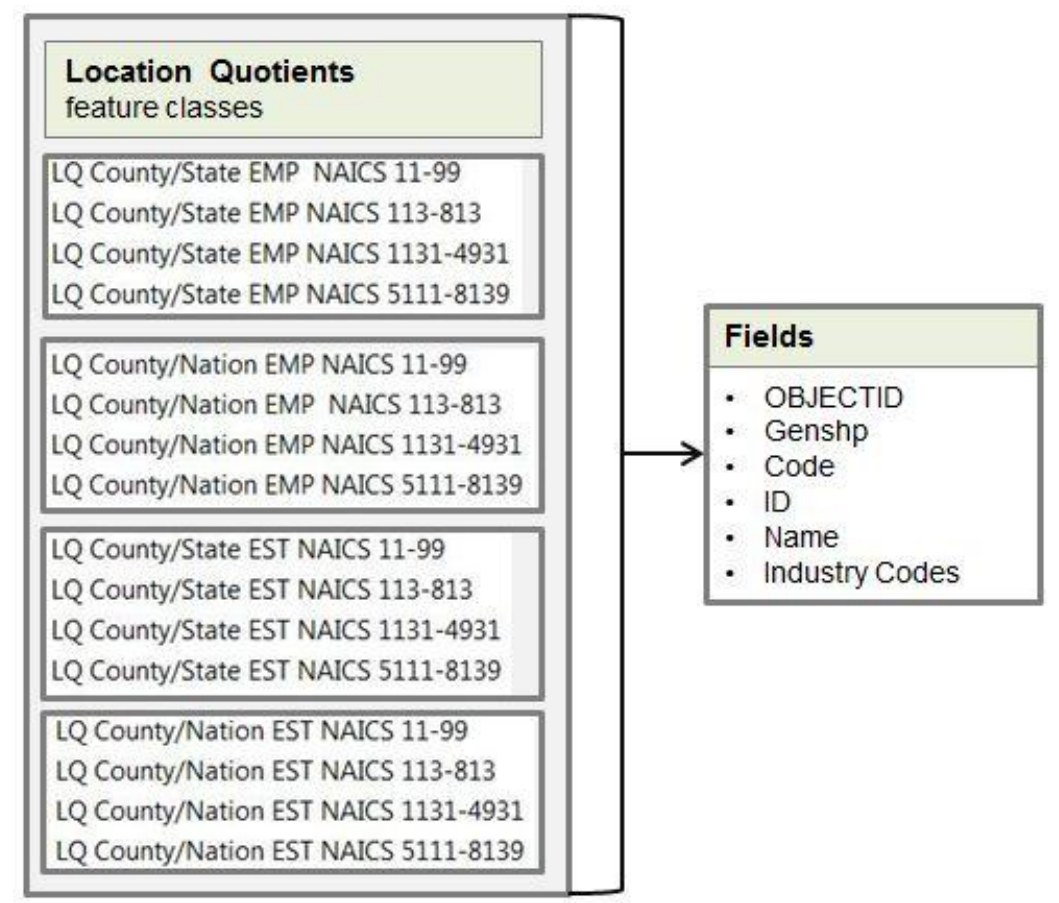

\section{Figure 4-3: Location Quotient Database Layers}

The second logical data model describes the remaining feature classes for this project and their associated attributes (Figure 4-4). The IndustryEmploymentZipCode feature class is a polygon class that contains data about the industry employment for zip codes throughout the study area. Next, the EducationalandTrainingFacilities point feature class provides the location of educational institutions throughout the study area. The 
EducationalAttainmentCensusTract feature class is a polygon feature class containing information about the educational attainment of local residents at the census tract unit boundaries. All feature classes and their respective attributes are accessible through the application.

\begin{tabular}{l} 
IndustryEmploymentZipCode \\
feature class \\
\hline Fields \\
- OBJECTID \\
- Shape \\
- Zip Code \\
- Name \\
- County ID \\
- County Name \\
- Total Population \\
- Employed Civilian Population \\
- Agriculture \\
- Mining \\
- Construction \\
- Manufacturing \\
- Wholesale Trade \\
- Retail Trade \\
- Transportation \\
- Utilities \\
- Information \\
- Finance/Insurance \\
- Real Estate \\
- Professional Services \\
- Management \\
- Admin/Waste Services \\
- Education \\
- Health Care \\
- Arts and Entertainment \\
- Accommodation/Food Services \\
- Public Administration \\
\hline
\end{tabular}

\begin{tabular}{|c|c|}
\hline $\begin{array}{l}\text { EducationalandTrainingFacilities } \\
\text { feature class }\end{array}$ & $\begin{array}{l}\text { EducationalAttainmentCensus Tract } \\
\text { feature class }\end{array}$ \\
\hline $\begin{array}{l}\text { Fields } \\
\text { - OBJECTID } \\
\text { - Shape } \\
\text { - Name } \\
\text { - City } \\
\text { - Zip Code } \\
\text { - NAICS Code }\end{array}$ & $\begin{array}{l}\text { Fields } \\
\text { - OBJECTID } \\
\text { - Shape } \\
\text { - } \text { TractID } \\
\text { - Base Population } \\
\text { - } \text { Less than } 9^{\text {th }} \text { Grade } \\
\text { - } 9^{\text {th }}-12^{\text {th }} \text { Grade } \\
\text { - High School Graduate } \\
\text { - Some College } \\
\text { - } \text { Associate Degree } \\
\text { - Bachelor's Degree } \\
\text { - Grad/Professional Degree }\end{array}$ \\
\hline
\end{tabular}

\section{Figure 4-4: Supporting Database Layers}

\subsection{Data Sources}

The data for this project was obtained from two sources. First, the data used to calculate the LQs (and used in the LocationQuotients feature classes) was derived from the Census Bureau's County Business Patterns (CBP) 2008 datasets. This dataset was released in July 2010. The CBP data "are used to benchmark public and private sector business statistical series, surveys and databases between economic census years. Federal agencies also use the data to determine employee concentrations and trends by industry" (U.S. Census, 2011b). The CBP data was accessed and downloaded as Excel files from the American Fact Finder website. Industry data for the US, California, and California counties were downloaded as separate files and merged into a single Excel table. The industry data included employment and establishment numbers for all 2, 3, and 4 digit NAICS codes. First-quarter and annual payroll data were eliminated from the compiled data. Finally, industry data for Los Angeles, Orange, San Bernardino, Riverside, and Orange counties were selected from the compiled table.

Esri's Business Analyst Desktop 2008 datasets (including business data provided by InfoUSA) were used for the remaining feature classes: IndustryEmploymentZipCode, 
EducationalandTraninigFacilities, and EducationalAttainmentCensusTract. Business Analyst provides "more than 1,600 variables about employee population, population by occupation/industry, disposable income, and consumer expenditures all at the United States, state, county, ZIP Code, census tract, block group, core-based statistical area, and designated market area geography levels" (Esri, 2011). Access to the Business Analyst datasets was provided by the University of Redlands MS GIS program.

County, zip code, and census tract polygon feature classes were exported from the Business Analyst datasets into the file geodatabase used in this project. Also taken from the Business Analyst datasets was a point feature class containing business locations (InfoUSA). All data was given in the GCS_WGS_1984 coordinate system.

\subsection{Data Scrubbing and Loading}

The CBP and subsequent LQ data required to meet this project's objectives had to be prepared for use in ArcMap. This data needed to be joined to the county feature class provided by Business Analyst. However, due to the data confidentiality of individual businesses, many industry sections and groups only contain coded values for the number of employees. To replace these letter codes with numerical values for LQ calculation, an estimation method was applied. This method will be discussed in detail in Chapter 5. The following section will describe briefly the process of reducing the Business Analyst dataset used in this project.

\subsubsection{Business Analyst Data}

In addition to the county feature classes, Zip Code, Census Tract, and Educational Facilities feature classes were acquired from Business Analyst's 2008 datasets. The zip code and census tract feature classes were processed in a similar manner. The Select by Location tool was used with both feature classes to reduce the geographic coverage from including all of the US down to the project study area. Because administrative boundaries are not coincident, however, there are a few instances of overlap in the zip code feature class, as compared to the county study area. The data provided by Business Analyst includes over 1600 aggregated demographic attributes for each of the administrative units provided. However, for the purposes of this project only a handful of these attributes were needed. Therefore, the Delete Field tool was used with both the zip code and census tract feature layers. All attribute fields outside those mentioned in section 4.2 were eliminated

The Educational Features class was derived from the infousa point feature class that is available with Business Analyst. This feature class contained 12,354,421 business locations across the US. The Select by Location tool was used first to reduce the feature class to the study area, leaving 78, 6076 business locations (saved as businesses). These businesses are organized in part by the attribute field NAICS_EXT which gives an 8-digit code to each facility. For this project, only the first four digits were necessary to be able to select those associated with education and training. So, a new field was added and named NAICS_4. Using the field calculator, the string function Left ([businesses], 4) extracted the necessary characters and populated the new field. Finally, the Select by Attribute tool was used to acquire all businesses location within the study area that were 
identified by a $6112,6113,6114$, and 6115 NAICS code. This resulting feature class was named NAICS_611.

\subsection{Summary}

This chapter detailed four major components of the database design process. The conceptual and logical data models illustrate the primary entities and association used in the project. Before the data could be loaded into ArcMap and subsequently used in the Web application, significant preparation was needed. An estimation method was developed to overcome data suppression issues associated with the CBP employment datasets. Business Analyst data sources needed to be tailored to meet the project objectives. 


\section{Chapter 5 - Implementation}

Chapter 5 discusses the project execution, which includes estimating missing data for location quotient calculation and displaying the location quotient feature classes on the web. The web application was created using a map template provided by Esri, which was further customized using the ArcGIS Javascript API development framework.

\subsection{Missing Value Estimation}

The Industry Specialization Identification Web Application's primary function of the Web application is to display LQ values for selected industries and levels of comparison. In order to provide this information, the employment data from the County Business patterns (CBP) needed to be reformatted and calculated. Figure 5-1 shows an example of the compiled Excel file containing the selected county, state, and US data mentioned in Section 4.3.

\begin{tabular}{|c|c|c|c|c|c|c|c|c|c|c|c|c|c|c|}
\hline D & E & $\mathrm{F}$ & H & 1 & K & L & $p$ & Q & s & T & y & z & $A B$ & $A C$ \\
\hline Geographic Area Name & NAICS & S Meaning of 2007 NAICS code & EST & EMP & County_tEST & County_tEMP & CA_EST C & CA_EMP & CA_tEST & CA_tEMP & US_EST & US_EMP & US_tEST & US_tEMP \\
\hline Los Angeles County, CA & 212 & Mining (except oil and gas) & 28 & 642 & 250,255 & $3,910,429$ & 303 & 6,638 & 8879,025 & $13,742,925$ & 6,935 & $5 \quad 205,652$ & $7,601,169$ & $120,903,551$ \\
\hline Los Angeles County, CA & 213 & Support activities for mining & $37 f$ & & 250,255 & $3,910,429$ & 338 & 10,976 & 879,025 & $13,742,925$ & 12,512 & 316,519 & $7,601,169$ & $120,903,551$ \\
\hline Los Angeles County, CA & 221 & Utilities & $240 \mathrm{j}$ & & 250,255 & $3,910,429$ & $1,103 \mid$ & & 879,025 & $13,742,925$ & 16,960 & 639,403 & $7,601,169$ & $120,903,551$ \\
\hline
\end{tabular}

Figure 5-1: Combined County Business Patterns Data

Some of the employment data provided by the CBP is suppressed to "avoid disclosure of information about individual employers" (U.S. Census Bureau, 2011b). For example, the column "EMP" in Figure 5-1 represents the number of employees working in each industry group. However, some of the cells only contain letter codes such as $f$ and $j$ (referred to as flagged data), instead of specific numerical values. Therefore, an estimation method was used (where necessary) to convert flagged data cells into employment numbers.

As described in Section 4.1, the sector, sub-sector, and industry group delineations are represented by a two, three, or four digit code, respectively. The two digit code branches into several three digit codes and so on. Due to the hierarchical structure of the NAICS codes, some flagged data cells (letter codes) can be replaced by the missing value in an industry set. This is the case when only one letter code is assigned for an industry set. For example, Figure 5-2 below shows the sub-sector industry set 711-713. The letter code $c$ has been assigned to sub-sector 712. When added together, this sub-sector industry set should equal its parent sector code 71 . Therefore, to find the missing value the given values for sub-sector codes 711 and 713 were added together, then subtracted from the given value for sector code 71. The letter code $c$ for sub-sector 712 can then be replaced with the remainder, 202. 


\begin{tabular}{|c|c|c|c|c|}
\hline \multicolumn{3}{|r|}{ Sector } & EST & EMP \\
\hline & 71 & $\begin{array}{l}\text { Arts, entertainment, and } \\
\text { recreation }\end{array}$ & 334 & 12,058 \\
\hline \multicolumn{5}{|c|}{ Sub-Sector } \\
\hline 711 & \multicolumn{2}{|c|}{$\begin{array}{l}\text { Performing arts, spectator sports, and } \\
\text { related industries }\end{array}$} & 106 & 1,320 \\
\hline 712 & \multicolumn{2}{|c|}{$\begin{array}{l}\text { Museums, historical sites, and similar } \\
\text { institutions }\end{array}$} & 11 & c \\
\hline 713 & \multicolumn{2}{|c|}{$\begin{array}{l}\text { Amusement, gambling, and } \\
\text { recreation industries }\end{array}$} & 217 & 10,536 \\
\hline \multicolumn{5}{|c|}{ Industry Group } \\
\hline 7111 & \multicolumn{2}{|c|}{ Performing arts companies } & 18 & $f$ \\
\hline 7112 & \multicolumn{2}{|c|}{ Spectator sports } & 14 & 200 \\
\hline 7113 & \multicolumn{2}{|c|}{$\begin{array}{l}\text { Promoters of performing arts, sports, and } \\
\text { similar events }\end{array}$} & 20 & e \\
\hline 7114 & \multicolumn{2}{|c|}{ Agents and managers for public figures } & 6 & $\mathrm{~b}$ \\
\hline 7115 & \multicolumn{2}{|c|}{$\begin{array}{l}\text { Independent artists, writers, and } \\
\text { performers }\end{array}$} & 48 & 197 \\
\hline
\end{tabular}

\section{Figure 5-2: NAICS Coding Structure}

When there are more than one letter codes in an industry set, the missing values were estimated based on the mid-range value for each letter code. This is the most common approach and is recommended by the Census Bureau (Zhang, p.7, 2006). For example, Figure 5-2 above, shows flagged data cells for industry groups 7111, 7113, and 7114 . Table 5-1 shows the letter codes along with the range and mid-range values for these industry groups.

\section{Table 5-1: Flagged Data Example}

\begin{tabular}{|c|c|c|}
\hline Letter Code & Range & Mid-range \\
\hline b & $20-99$ & 60 \\
\hline e & $250-499$ & 375 \\
\hline f & $500-999$ & 750 \\
\hline
\end{tabular}

The parent class for this industry group is sub-sector 71. If the given values for this industry group are summed, then subtracted from the total of the parent class, a difference of 923 is determined $(1320-200-197=923)$. This value is the expected sum of the three missing values and therefore it is then proportionally distributed among the industry groups based on the mid-range values of their corresponding letter codes. For example, the estimated value for letter code $b$ of industry 7114 equals to the mid-range value of 
letter $b$ (60) divided by the sum of the mid-range values of all three letter codes $(60+375+750=1185)$ and then multiplied with the expected sum of $923(60 / 1185 * 923=$ 47). This process is summarized in Table 5-2.

\section{Table 5-2: Summary of Data Estimation Method}

\begin{tabular}{|c|c|}
\hline Data Estimation Method & Example \\
\hline 1. Identify a letter code range & $f, e, b$ \\
\hline $\begin{array}{l}\text { 2. Determine if it's a member of a } 2,3 \text {, or } 4 \text {, } \\
\text { digit set }\end{array}$ & 4 digit \\
\hline $\begin{array}{l}\text { 3. Determine the hierarchical position and } \\
\text { add all numeric codes in the same set. }\end{array}$ & $7111-7115$ \\
\hline $\begin{array}{l}\text { 4. Determine parent class and it's given } \\
\text { value }\end{array}$ & $711 ; 1320$ \\
\hline $\begin{array}{l}\text { 5. Add given values from the same set and } \\
\text { subtract from parent class value }\end{array}$ & $1320-397=923$ \\
\hline $\begin{array}{l}\text { 6. If only a single value is missing the replace } \\
\text { the letter code with the remainder }\end{array}$ & $\begin{array}{l}\text { For example, in the } 711-713 \text { set, } 712 \text { has a } \\
\text { letter code of c. When the set is added } \\
\text { together then subtracted from the parent } \\
\text { class value }(12,058-11856=202) \text { the } \\
\text { remainder of } 202 \text { replaces the letter code } c \text {. }\end{array}$ \\
\hline $\begin{array}{l}\text { 7. If there is more than one letter code in a } \\
\text { set, determine the mid-range value for each } \\
\text { and sum them together. }\end{array}$ & $\left.\begin{array}{l}f=750 \\
e=375 \\
b=60\end{array}\right]=1185$ \\
\hline $\begin{array}{l}\text { 8. Disperse the remainder proportionally } \\
\text { among the mid-range values by adding or } \\
\text { subtracting (round appropriately). }\end{array}$ & $\begin{array}{l}f-750 / 1185 \times 923=584 \\
\text { e- } 375 / 1185 \times 923=292 \\
\text { b- } 60 / 1185 \times 923=47\end{array}$ \\
\hline
\end{tabular}

In cases where a valid estimation could not be produced, a value of -9999 was used to substitute the letter code. This value was also used in cases where the county did not provide data for a particular industry.

The compiled Excel table, now containing all LQ values, was broken down into sixteen separate tables based on level of comparison and NAICS code. This was done, in part, because there is a 255 character limit when performing table joins from an Excel file into ArcMap. Characters beyond the 255 limit are converted to a binary large object (BLOB) type and cannot be read (http://help.arcgis.com, 2011b). Once joined to the sixteen separate county feature classes, all demographic data were eliminated using the Delete Field tool. 


\subsection{Web Map Application}

The main objective of this project was to develop a Web application, which involved two primary functions. One is to display the user- selected location quotient (LQ) values as a choropleth class-breaks rendered graphic. This function displays the LQ values of each county according to industry specialization. The second function is to allow the user to select a county and have all the LQ values for that county display in the application using an identify function. Initial consideration was given to the ArcGIS API for Flex as the development framework. However, in order to provide the user with an interface that allowed for selection among the various LQ values through radio buttons and drop down menus, it was determined that the JavaScript API would most appropriately fit the project requirements. In addition, the JavaScript API supports the use of panels, which is the most appropriate format for the identify function to display the LQ values of each layer. The remaining feature classes, including IndustryEmploymentZipCode, EductaionalandTrainingfacilities, and EducationalAttainmentCensusTract, were also included in the application for visualization purposes. Analytical functions of performing a cluster analysis to be built upon over time. Data from these layers are viewable through the identify function and are displayed in a panel on the Web application.

\subsubsection{Preparing map documents for publication}

Steps to prepare the map documents for publication included: changing the map coordinate system, changing field alias, modifying LQ values, and setting the map scales. The first step was to set the coordinate system of all feature classes to WGS 1984 Web Mercator (Auxiliary Sphere). This was done because the world imagery with labels basemap that was added from ArcGIS Online is based on this coordinate system. The field alias names for all 1600 industry codes were then changed to provide more useful descriptions for the identity function. Figure 5.3 shows an example of the field alias change. 


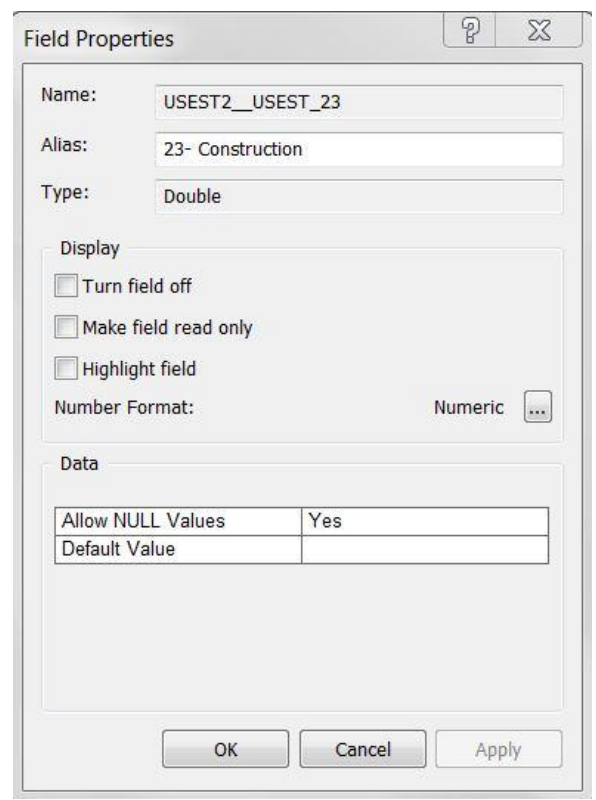

\section{Figure 5-3: Field Alias Change}

Next, all LQ values were changed to display values with two decimal places instead of six, as LQ values are traditionally provided with no more than two decimal places. The first two decimal places determine the type of classification value assigned to the industry in the Web application. For example, the class-breaks rendered graphic identifies any value greater than 1.25 and less than 2.0 as being associated with a pre-selected color, and displays that color on the map. The map scale schema was changed to match the scale set used by ArcGIS. Finally, the data for the sixteen feature classes containing the LQ values were saved to ArcSDE, since these feature classes were used as feature services in the class breaks renderer. It was not necessary to repeat this process for the remaining layers because they were published as map services.

\subsubsection{Publication}

Before publication, several map documents were created in ArcMap. One document was created for all sixteen location quotient feature classes and saved as LocationQuotients.mxd (Figure 5.4). 


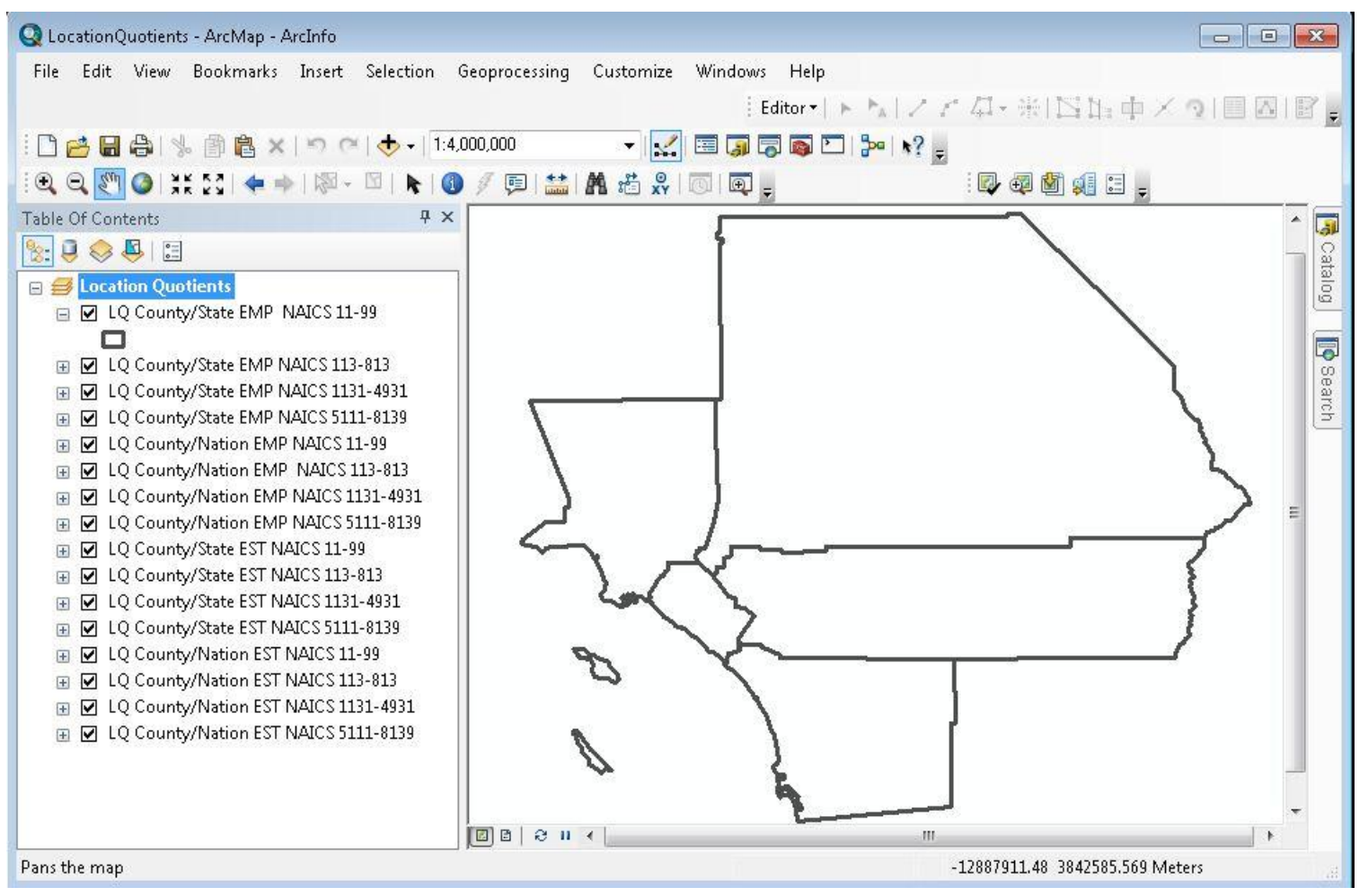

\section{Figure 5-4: LocationQuotients ArcMap Document}

Map documents for each remaining feature class (IndustryEmploymentZipCode, EducationalandTraninigFacilities, and EducationalAttainmentCensusTract) were created separately so that the identify function would group the results logically. All map documents were published to the ArcGIS Server through ArcCatalog and added to a list in the ArcGIS Services Directory (Figure 5-5). 


\begin{tabular}{l} 
ArcGIS Services Directory \\
Home \\
\hline
\end{tabular}

\section{Folder: /}

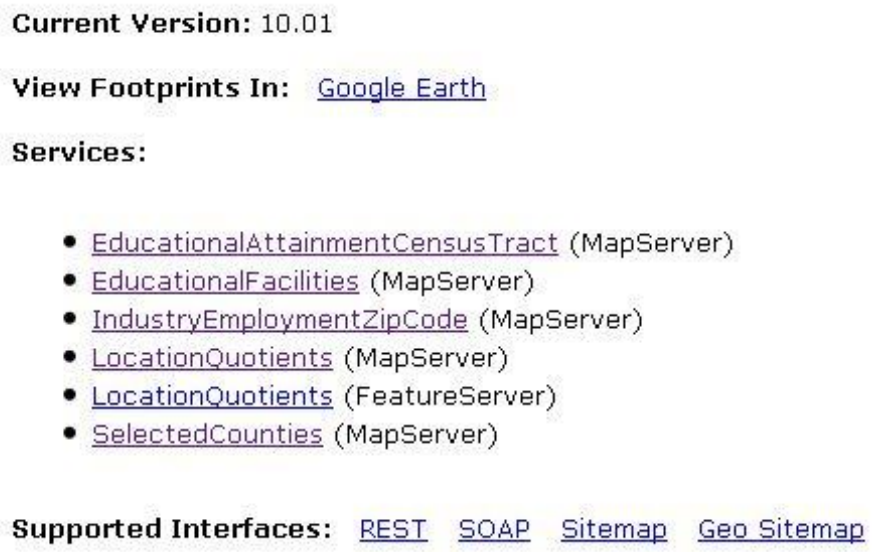

\section{Figure 5-5: Service Directory}

The LocationQuotients feature service was assigned sixteen unique IDs, ranging from 0 to 15. All layers were added to an ArcGIS Web application, saved as Industry Cluster Identification (Figure 5-4), and assigned the unique ID of ac72baee6bed4957bd6519c11c5e3b00. This application was made public so that its contents could be referenced in any customized application.

\section{Industry Cluster Identification}

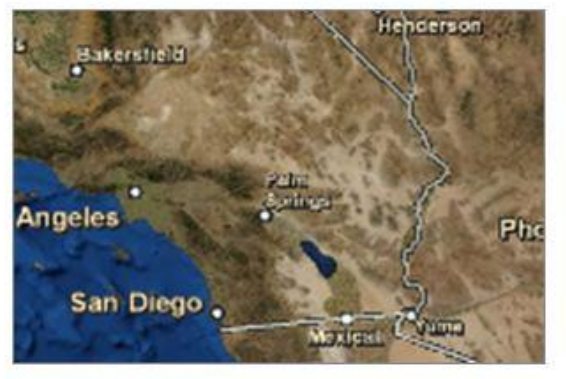

Web Map by sgoose (last modified: July 5, 2011)

ind

Facebook $\%$ Twitter

\begin{tabular}{|c|c|c|c|c|}
\hline Open $\mathbf{}$ & Og Share & Edit & X Delete & -3 Move To \\
\hline
\end{tabular}

Figure 5-6: Sharing ArcGIS Web Application

Once publically shared, ArcGIS offers several web application templates that can be used for customization. For this project, the Chrome Identify template was selected. 
This template had three panels available: one to display descriptive content, one to hold the map application, and one to display the identify results. This template was downloaded as a zip file and was saved locally. The unmodified template is shown in Figure 5-7.

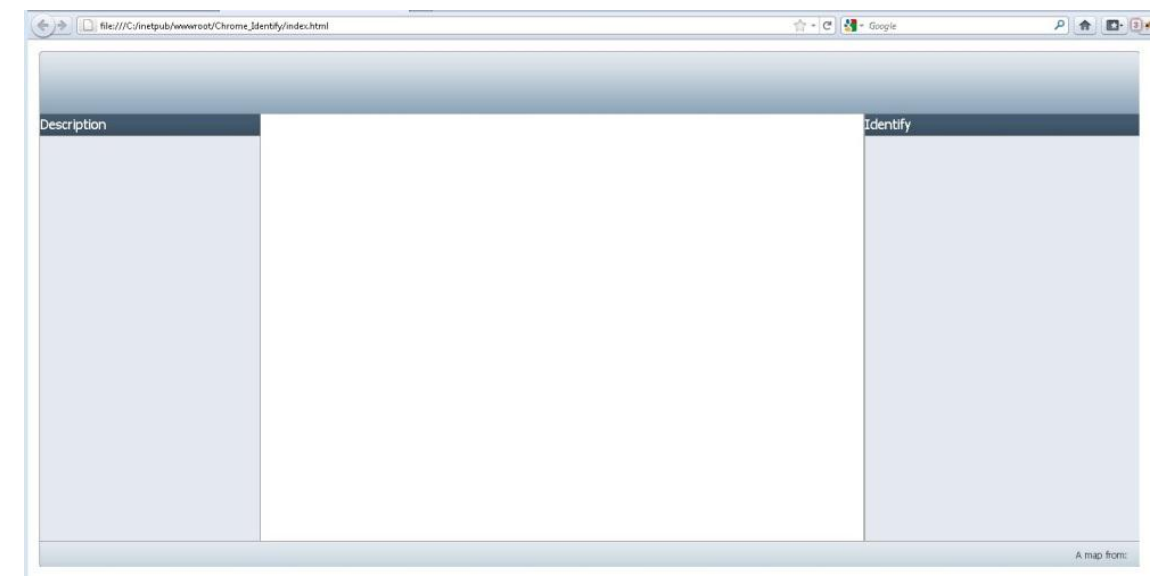

\section{Figure 5-7: ArcGIS Chrome Identify Template}

\subsubsection{Application Development and Customization}

Microsoft Visual Studio 2010 was used to customize and compile the Web application. The application file folder was named icd (industry cluster data) and contains two distinct pages both of which will be discussed here. The first page was developed as the primary user interface. Written in HTML (Hypertext Markup Language), this page presents the user with the selection options for the LQ values (Figure 5-8).

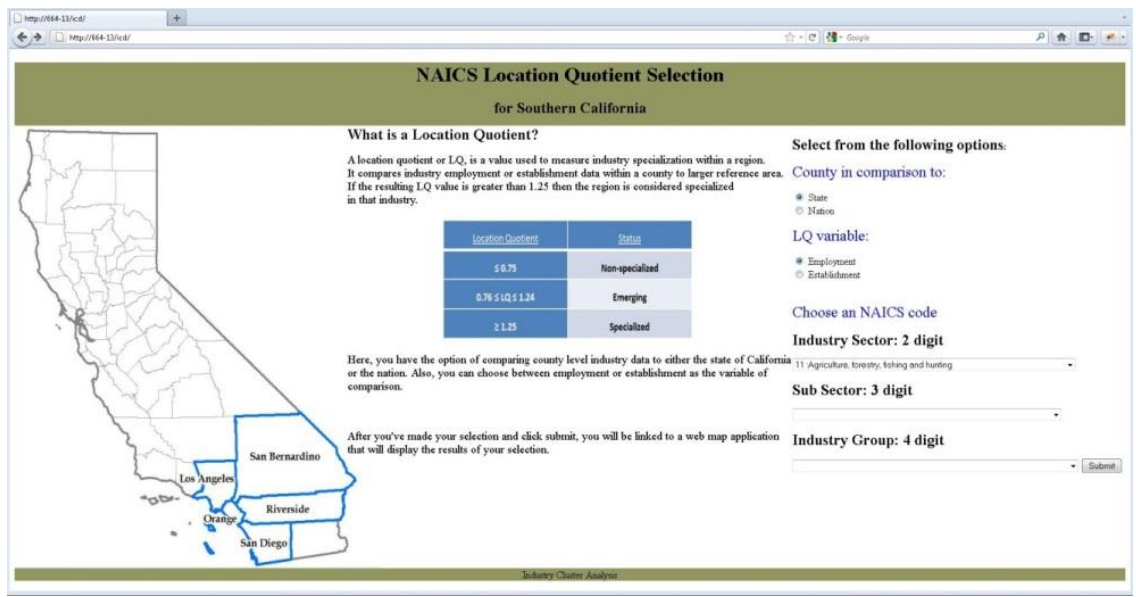

Figure 5-8: Application Page One 
The radio button and drop-down list options are called forms and are "used to pass data to the server" (w3schools.com, 2011). This is the page the user sees when first accessing the Web application (Default.aspx). This opening page provides a brief explanation of industry clusters and how to interpret LQ values. It also shows a locator map that identifies the counties in the study area. Here, the user can make selections using radio buttons on the LQ level of comparison (state or nation) and variable (employment or establishment). Then, the user can decide on the NAICS code of interest by selecting from a choice of three drop-down lists: Industry Sector, Sub-Sector, or Industry Group (figure 5-10). When the user clicks on the submit button they are redirected to the mapping application and the second page of the website.

This second page displays the results of the inquiry as a choropleth class-breaks rendered graphic. The values and colors were set as follows:

- $\quad 0.0-0.75$, Non-Specialized, Light Blue

- $0.76-1.24$, Emerging, Light Green

- 1.25-2.0, Low Specialization, Orange

- 2.01>, Highly Specialized, Red

Figure 5-9 shows an example of the second page. This example is for county/nation employment, industry group 3152, cut and sew apparel manufacturing.

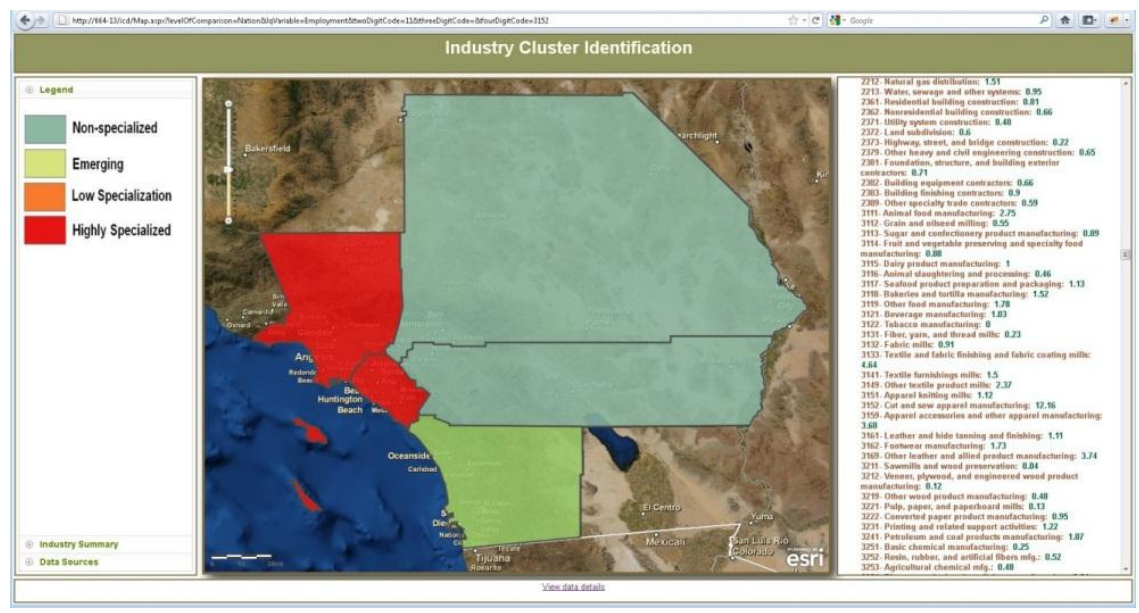

\section{Figure 5-9: Application Page Two}

Additionally, three tab containers were customized in the JavaScript file (layout.js) to hold the map legend, industry summary reports (see Appendix), and data source information. Users can access the contents of these tabs by clicking on the tab descriptions. These containers replaced the original left panel of the Chrome Identify template. The class breaks renderer function was also added to the layout.js file and displays in the center panel. Figure 5-10 shows the tab containers and the rendered graphic as well as the identity panel which will be discussed next. 


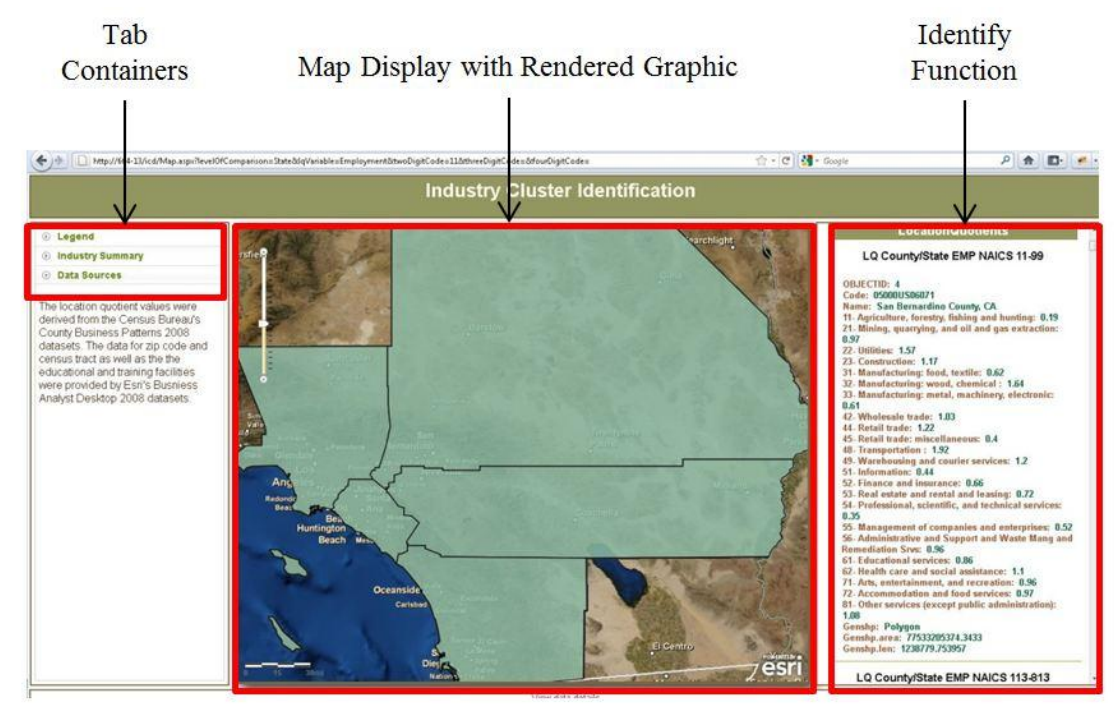

\section{Figure 5-10: ArcGIS Customized Template}

The identify function (webmap.identify.js) was configured to run with the Default.aspx file and displays in the right panel. Several style customizations were made to both the layout and webmap.identify CSS (Cascading Stylesheet) files to improve the presentation and cohesiveness of the application.

\subsection{Summary}

This chapter discussed the implementation of the Industry Specialization Identification project, which included saving data layers to ArcSDE and preparing map documents for publication. An ArcGIS template was customized using the ArcGIS JavaScript API and compiled with other necessary files to form a complete Web application using Microsoft Visual Studio. The resulting Web application was saved to a file named icd. The following chapter will go over a potential user scenario that will showcase the Web application as a valuable tool for economic and community planners. 



\section{Chapter 6 - Results and Analysis}

The first step toward implementing a cluster driven economic strategy is to identify and target a particular industry or industries within a predefined geographic region (Reid, 2007; Henton, 2007). This initial analysis is necessary for economic developers to direct limited resources to support industry clusters through workforce and other development programs. For example, "cluster information can be used to design a new community college or training program" (Henton, 2007, p.29). Targeting particular industry clusters can also allow community developers to build local collaborative and partnerships between private companies, industry associations and research facilities. This chapter will outline a fictional scenario in which the Industry Specialization Identification Web application would be useful in this initial analysis.

San Bernardino County has an expansive network of community colleges and training centers. Assume there is a need to develop a new program for the community, which will focus on industry cluster workforce development. One industry cluster of interest is healthcare, as San Bernardino County is regarded as specialized in healthcare, specifically hospitals. First, the existence of a hospital industry cluster needs to be verified. A horizontal investigation will be performed using the two levels of comparison and the two given variables: county/state employment, county/nation employment, county/state establishment, and county/nation establishment, which adds up to four comparisons. Second, a vertical analysis is required to identify specialized industries within the cluster by looking into more detailed industry descriptions.

\subsection{Analyzing Specialization of an Industry Sub-Sector}

Figure 6-1 shows the first interface that the user will see when launching the web application, where the NAICS code for the healthcare industry is 62 from the drop-down menu (highlighted in red box). 


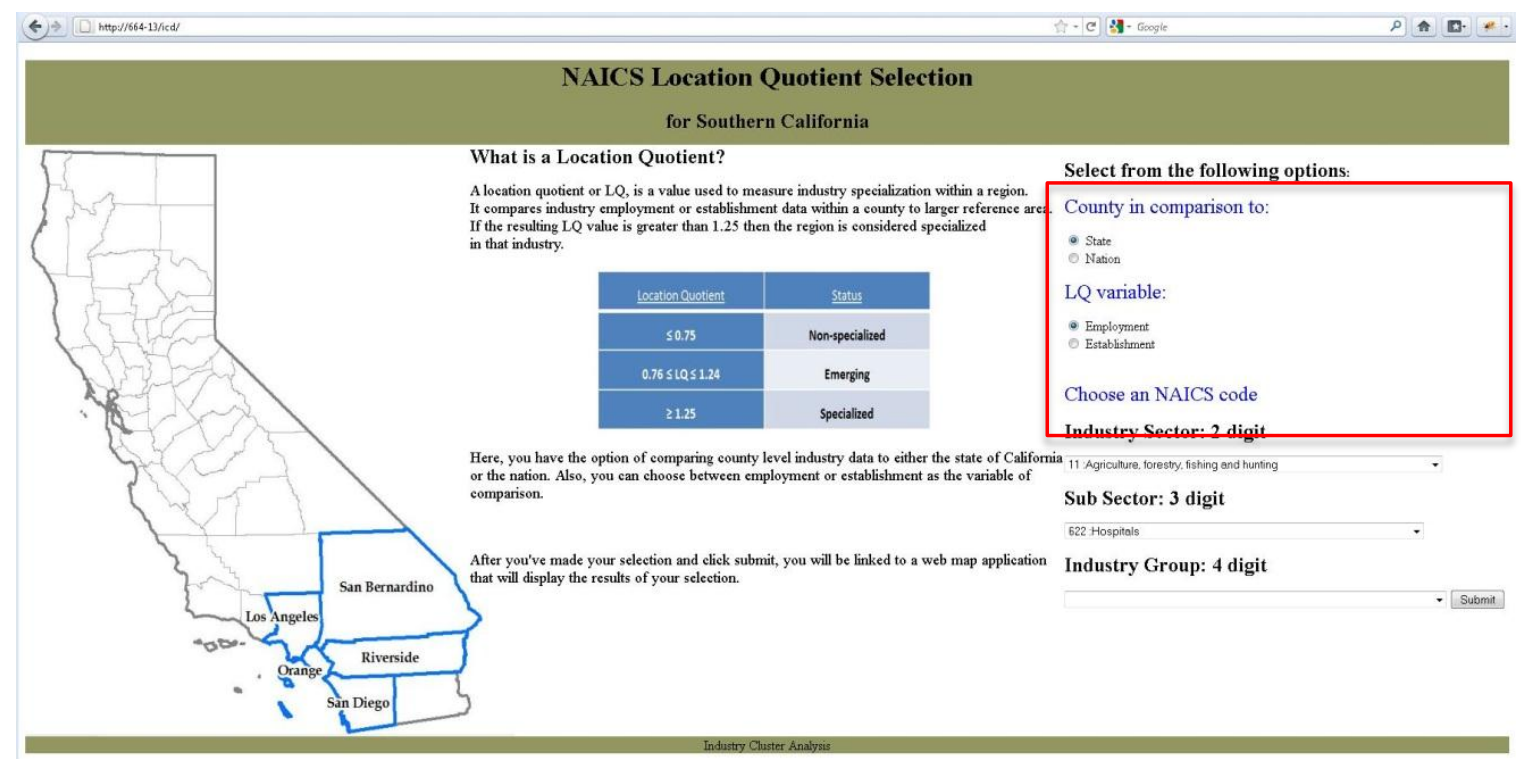

\section{Figure 6-1: Defining Queries}

Since the sub-sector of hospitals is of interest, the user can further evaluate the dropdown menu and the NAICS code for hospitals is 622 . Once this selection is made, the process is repeated for the remaining combinations. Figures ( 6-2, 6-3, 6-4, and 6-5) show the results of the inquiries.

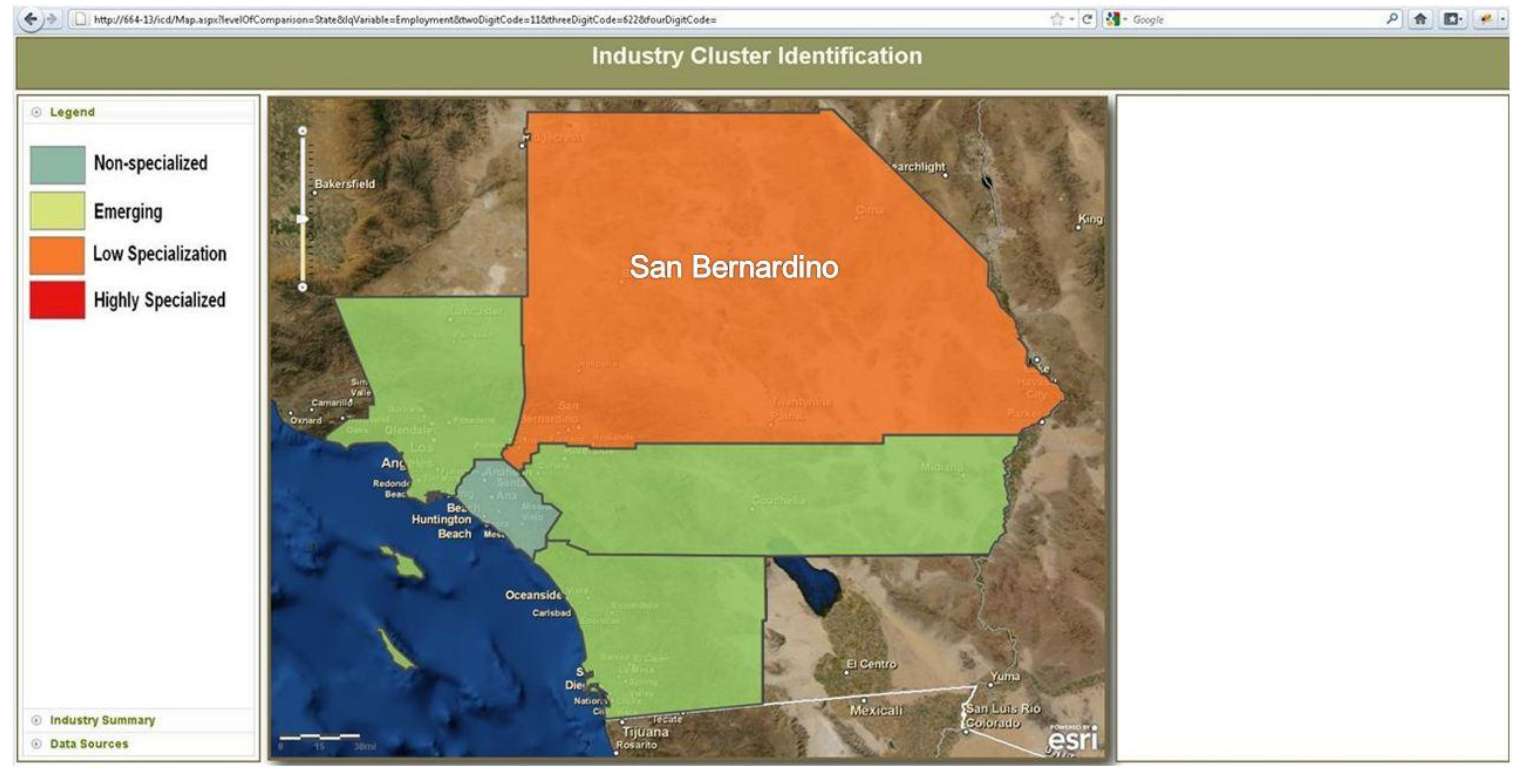

Figure 6-2: County/State Employment, NAICS 622- Hospitals 


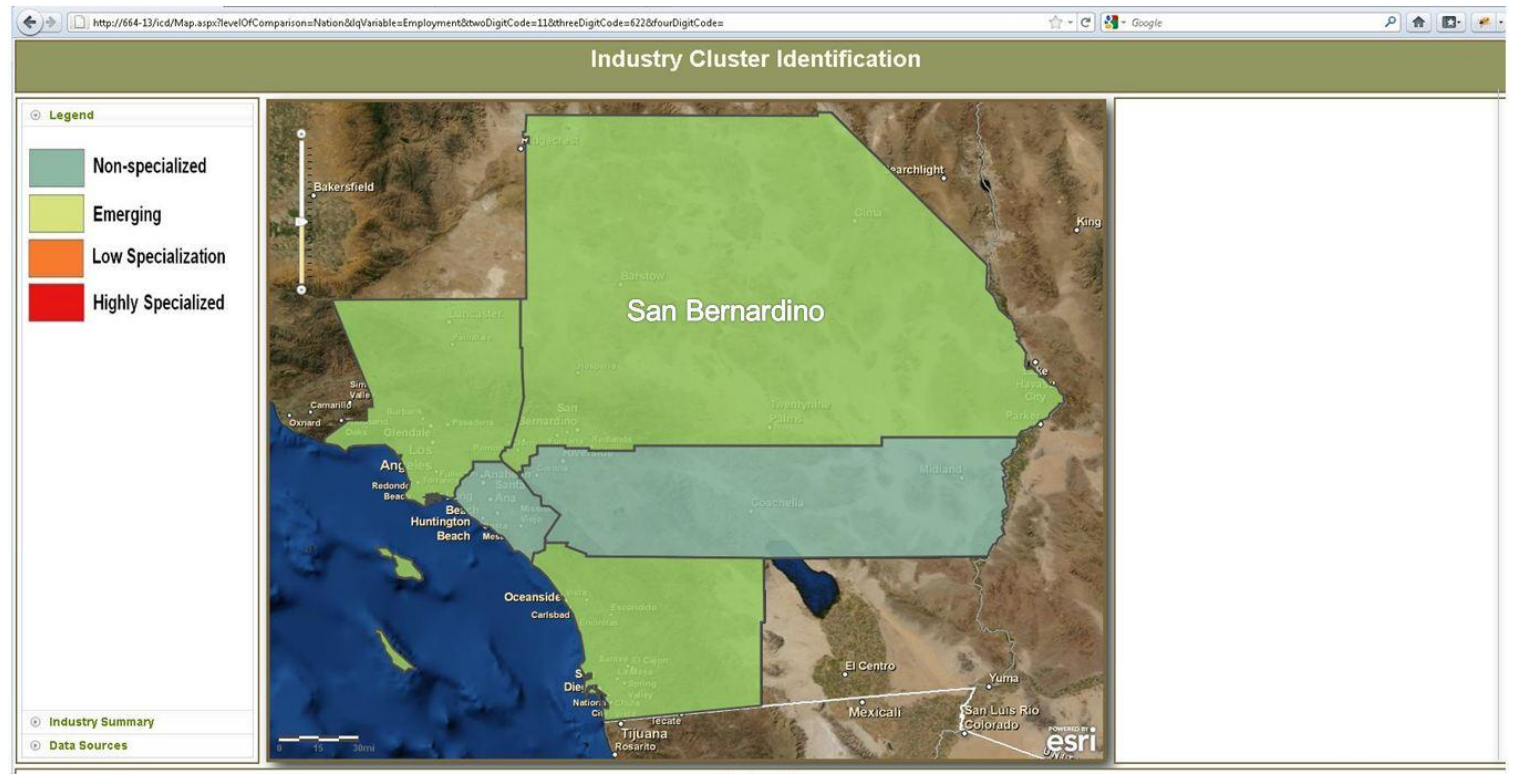

Figure 6-3: County/Nation Employment, NAICS 622- Hospitals

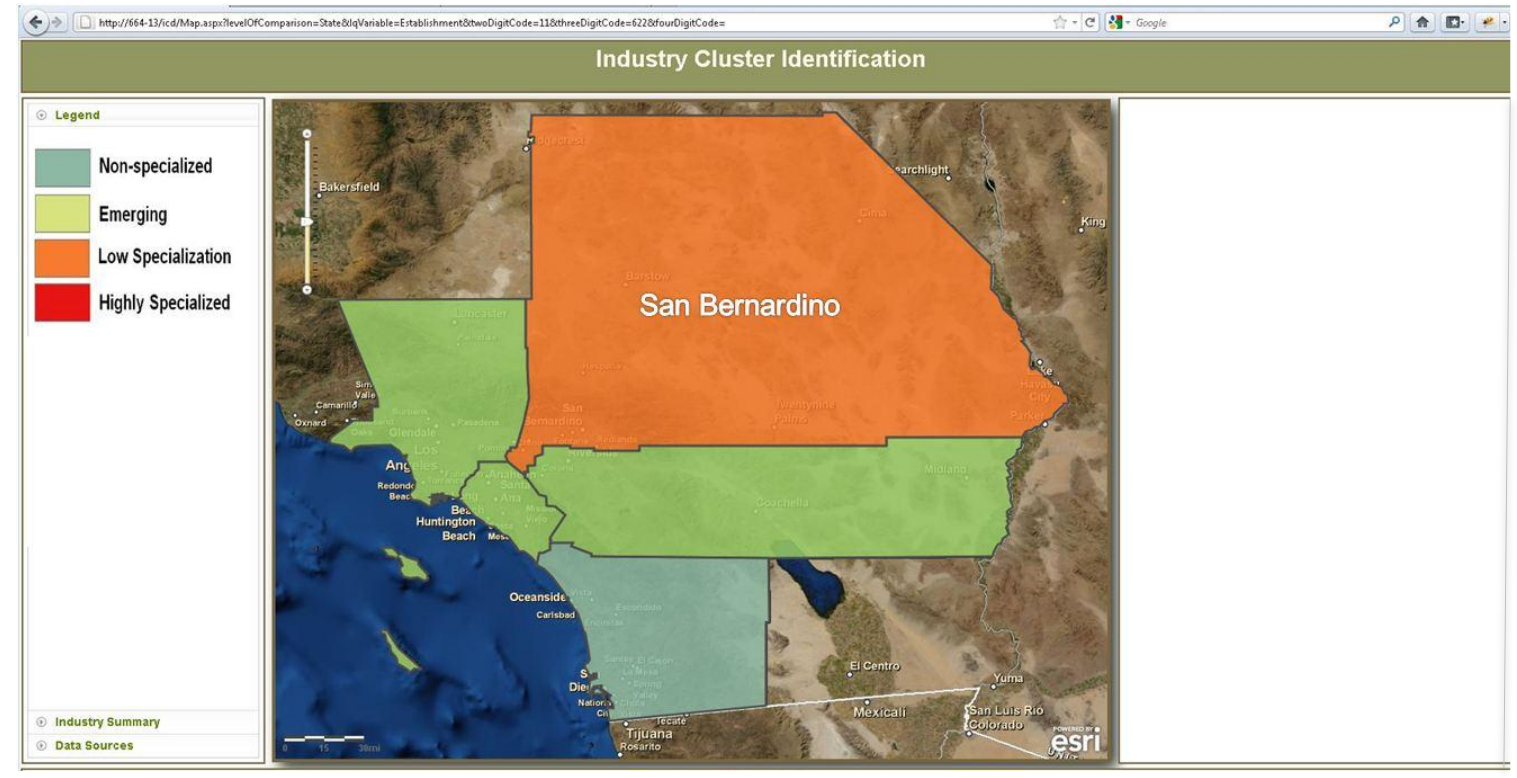

Figure 6-4: County/State Establishment, NAICS 622- Hospitals 


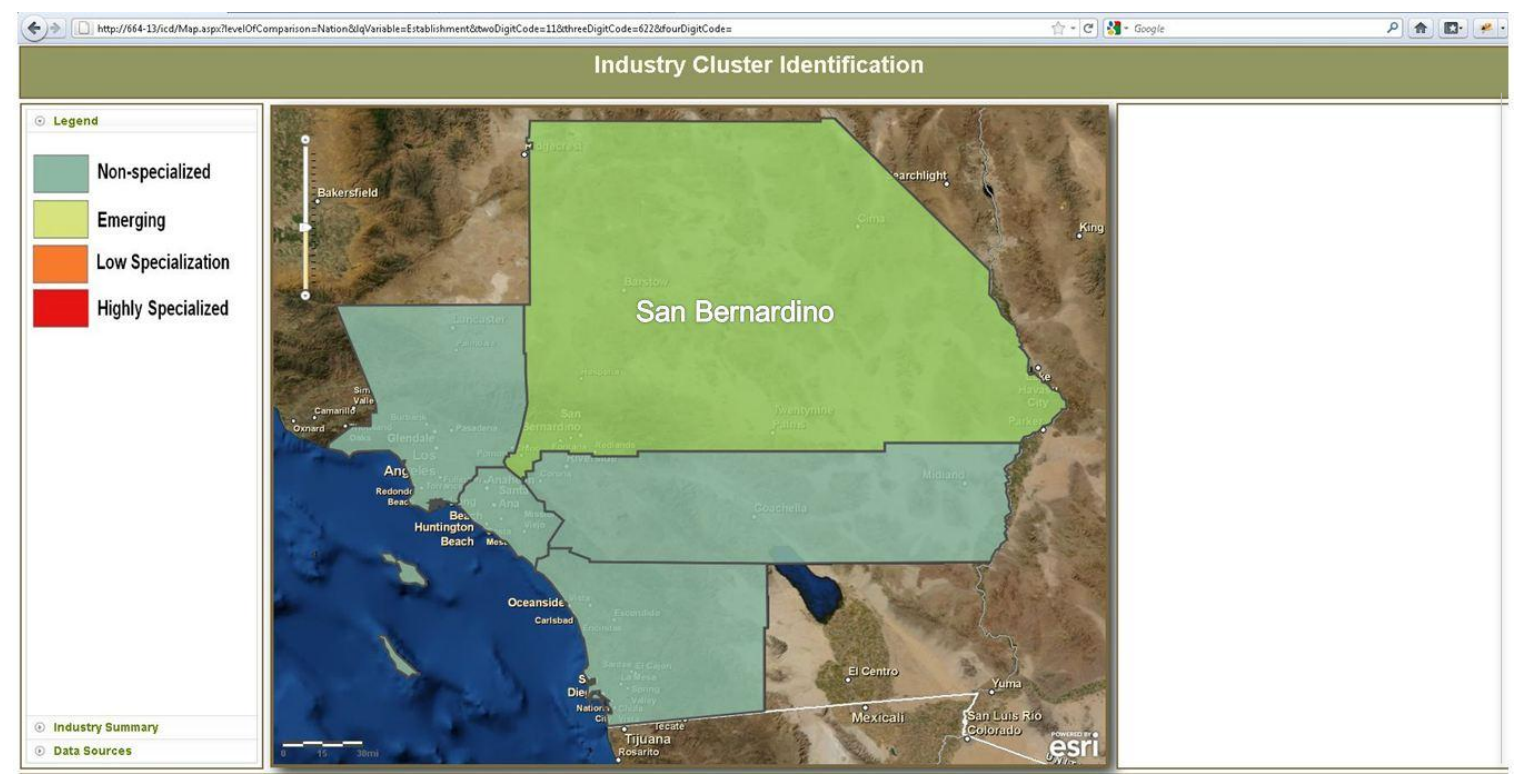

\section{Figure 6-5: County/Nation Establishment, NAICS 622- Hospitals}

Based on the comparison at the state and nation levels, an industry cluster for hospitals is confirmed to be present for San Bernardino County. The results of the first inquiry two inquiries (Figure 6-2 and 6-3) reveal that the specialization applies to both hospital employment and number of establishments when comparing the county to the state (of California), while there is not an evident industry specialization in hospitals when comparing the county to the nation (Figure 6-4 and 6-5). Further, all four comparisons indicate that San Bernardino most specialized this industry when compared to other nearby counties in the study area. The benefit of viewing industry specialization in a map as opposed to a spreadsheet is being able to evaluate a county with those that are nearby. Because the data used to calculate the location quotients is collected at the county level, the results seem to show the entire county of San Bernardino is specialized in hospitals. However, this is not the fact. San Bernardino County covers more than 20,000 square miles, but most economic activity takes place in the south west corner of the county. This is attributable to the physical geography and residential patterns within the county. Using the IndustryEmploymentZipCode layer contained in the Web application the user can examine a simple choropleth map that shows the spatial distribution of the population. Figure 6-6 shows the volume of population for the county residing near the southwest boundary. 


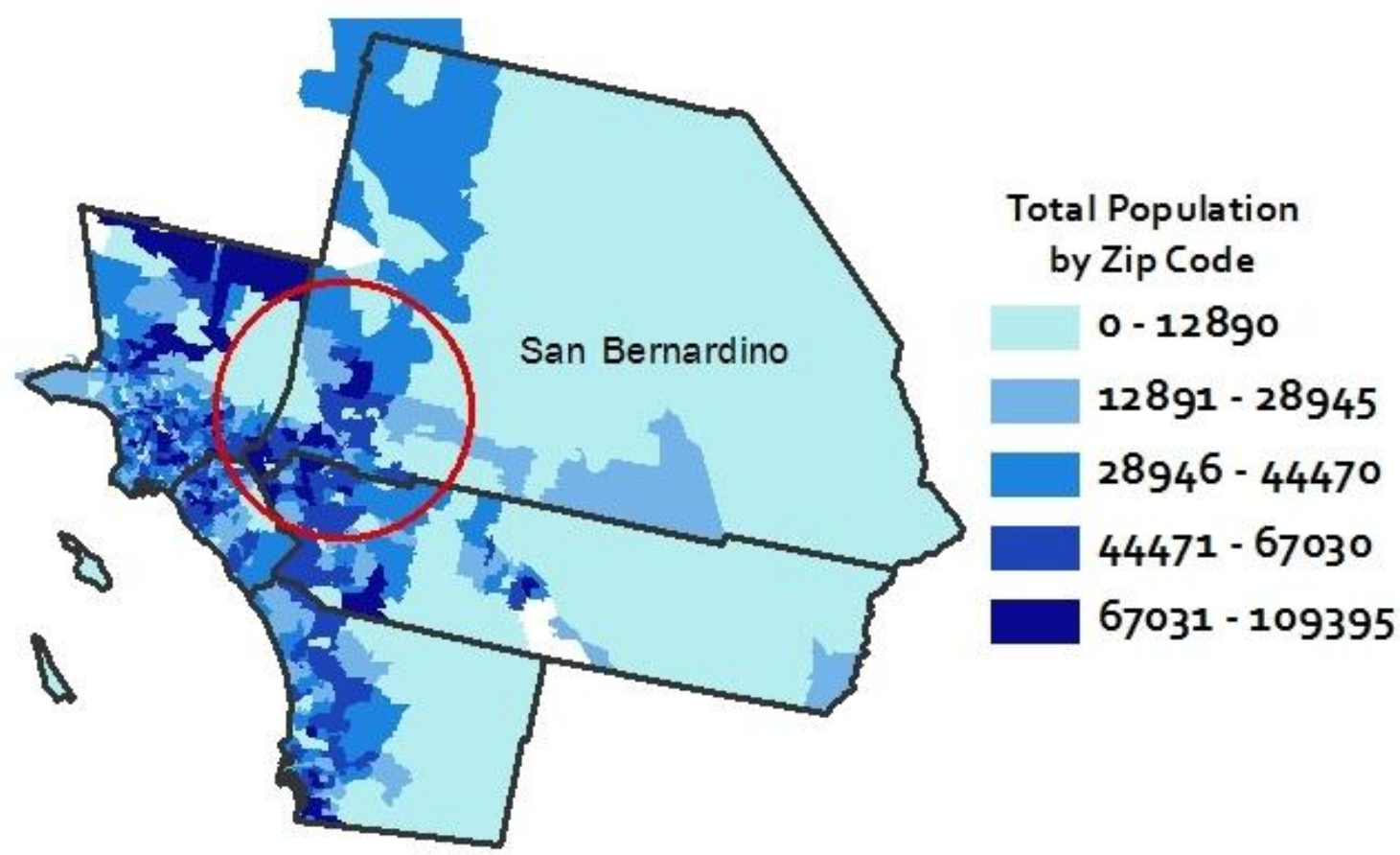

Figure 6-6: Population Distribution by Zip Code

The IndustryEmploymentZipCode layer can also be used to evaluate reported industry employment by residence but not by place of business. This discrepancy is important to be noted because it differs from the way the NAICS values on employment are collected. In other words, the LQ data is reported as employment by place of business and collected at the county level. Industry employment by zip code is reported by residence and only by NAICS two-digit sector. Thus, the data of industry employment by zip code are less detailed in assessing which particular industries people are employed in. However, the information is still useful for making decisions on how and where to best support identified industry clusters. For example, the number of people reporting employment (by zip code) in the healthcare industry for San Bernardino County is shown in figure 67. This result can be used to analyze how workforce availability affects the location of the planned programs. 


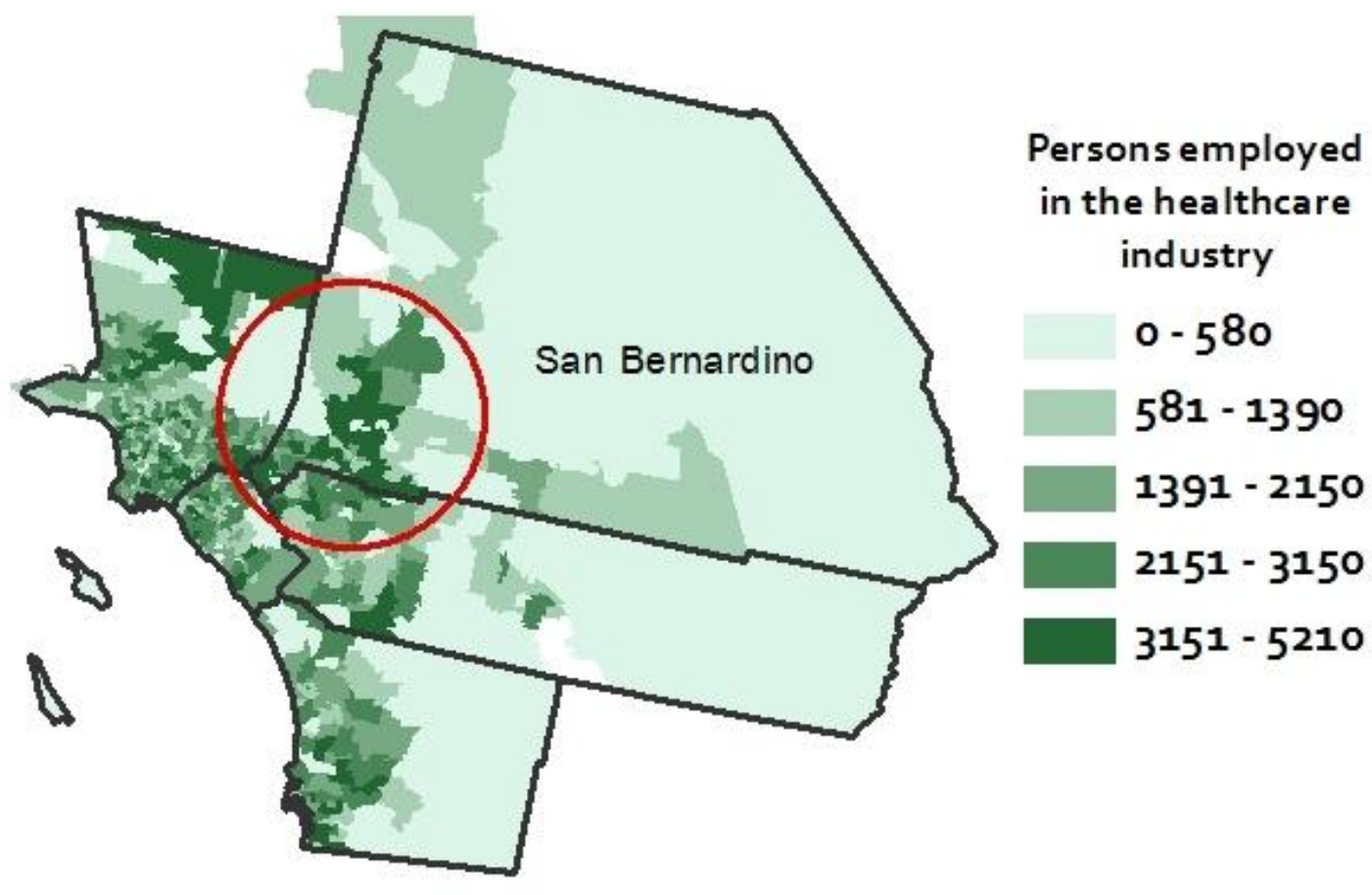

Figure 6-7: Employment by Zip Code, Healthcare Industry

\subsection{Analyzing Industry Groups within an Industry Cluster}

Once the existence of a hospital industry cluster for San Bernardino County has been verified (meaning the LQ value is large enough to indicate specialization and therefore the presence of a cluster), the industry groups within this cluster need to be examined further to identify the specific types of hospitals that make up the cluster. In this analysis, the focus will be only on employment as the variable. Employment is the standard variable and this inquiry will be used to direct resources toward workforce development, so variable reduction to employment is fitting. From the drop-down menu for industry group, three sub-sectors are listed: 6221-General medical and surgical hospitals, 6222Psychiatric and substance abuse hospitals, and 6223-Speciality hospitals. Figures 6-8 and 6-9 show the state and national LQ values of employment of general medical and surgical hospitals (NAICS 6221). It is obvious that San Bernardino has a low specialization in general medical and surgical hospitals in comparison to the state, but not when compared to the nation. 


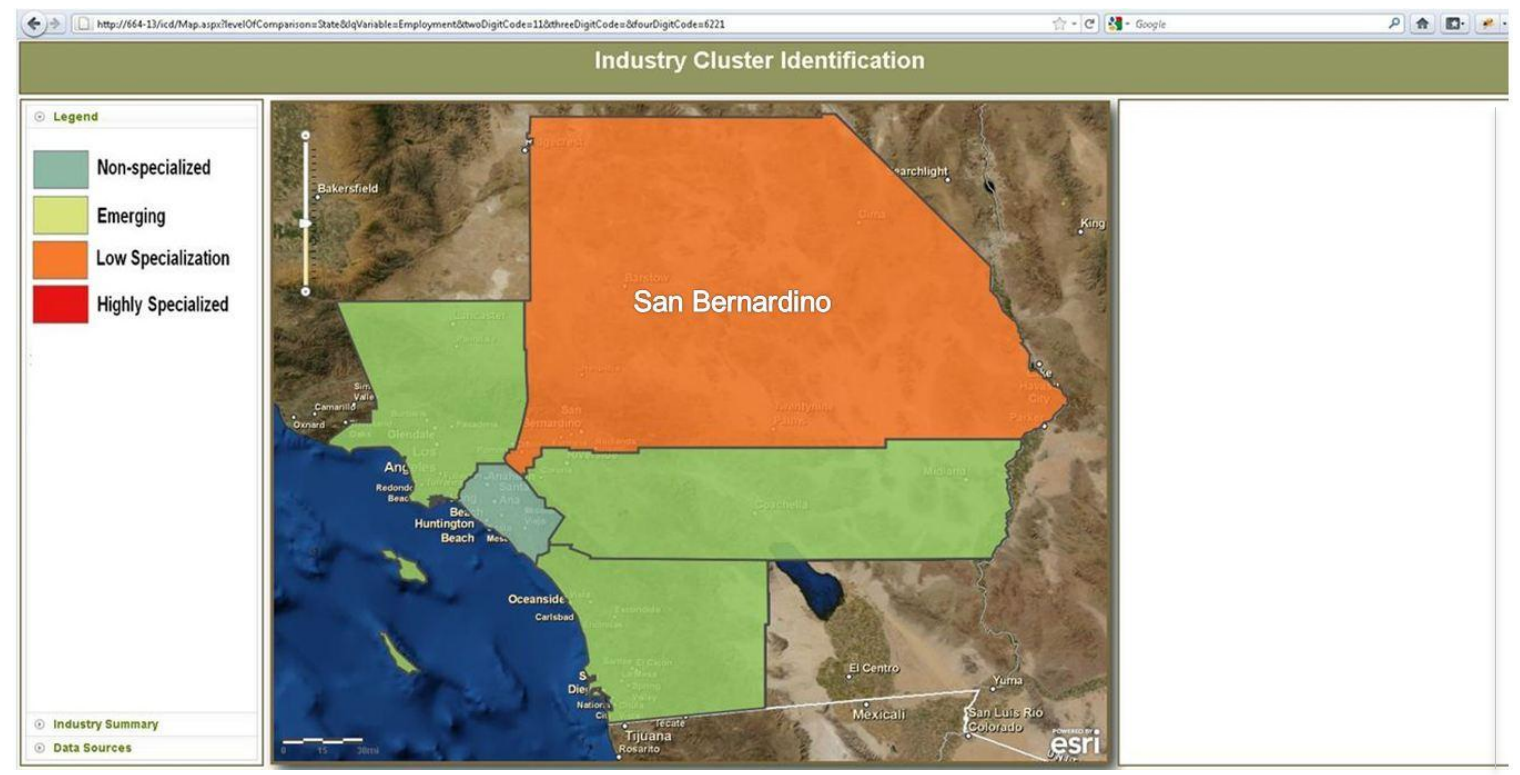

Figure 6-8: County/State Employment, NAICS 6221- General Medical and Surgical Hospitals

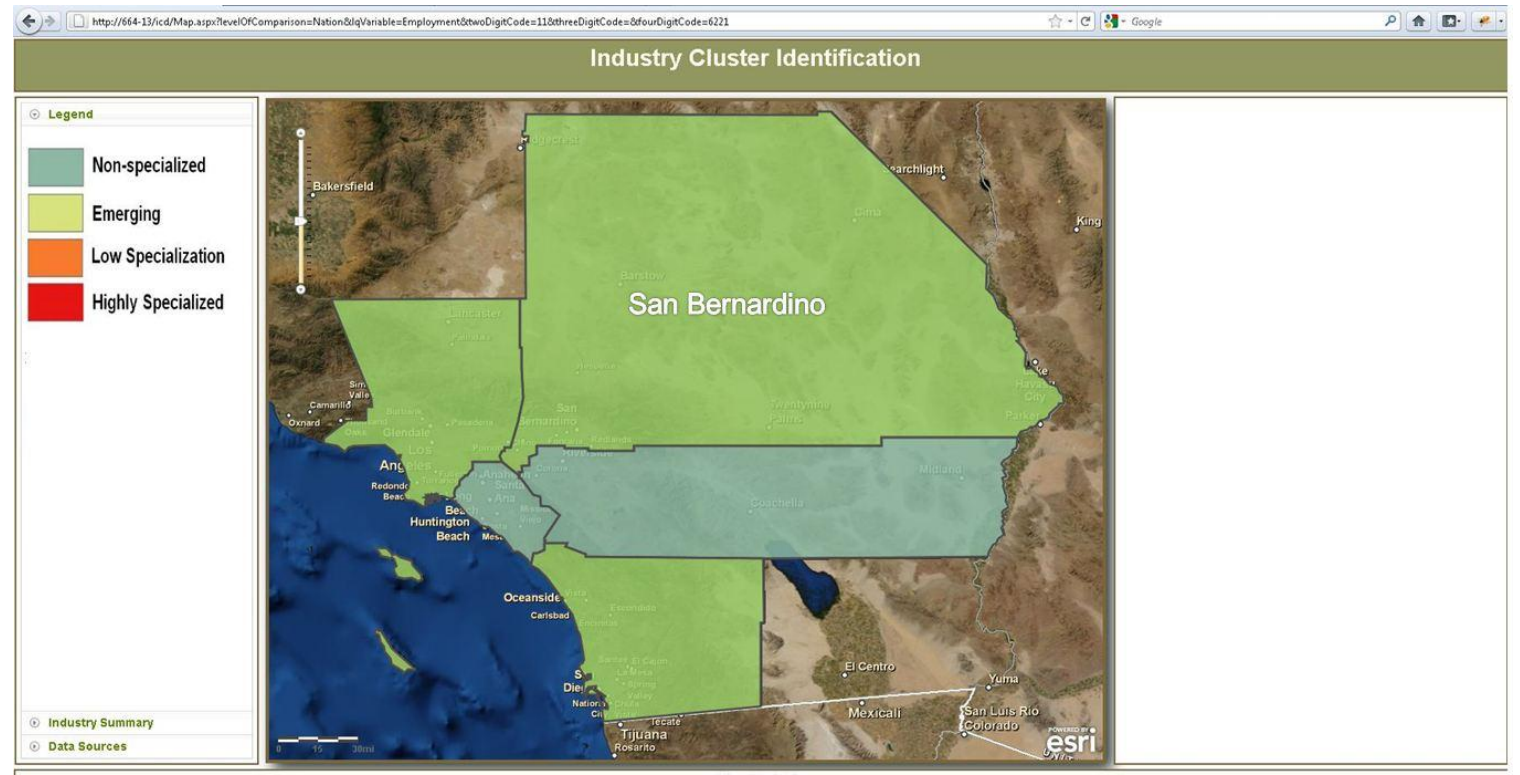

Figure 6-9: County/Nation Employment, NAICS 6221- General Medical and Surgical Hospitals

Figures 6-10 and 6-11 show the results of the second industry group - psychiatric and substance abuse hospitals (NAICS 6222). Both the state and national LQ values suggest a high specialization for this industry for San Bernardino County. However, this 
specialization does not extend to the other counties in the study area. The remaining counties are classified either into non-specialized or emerging categories.

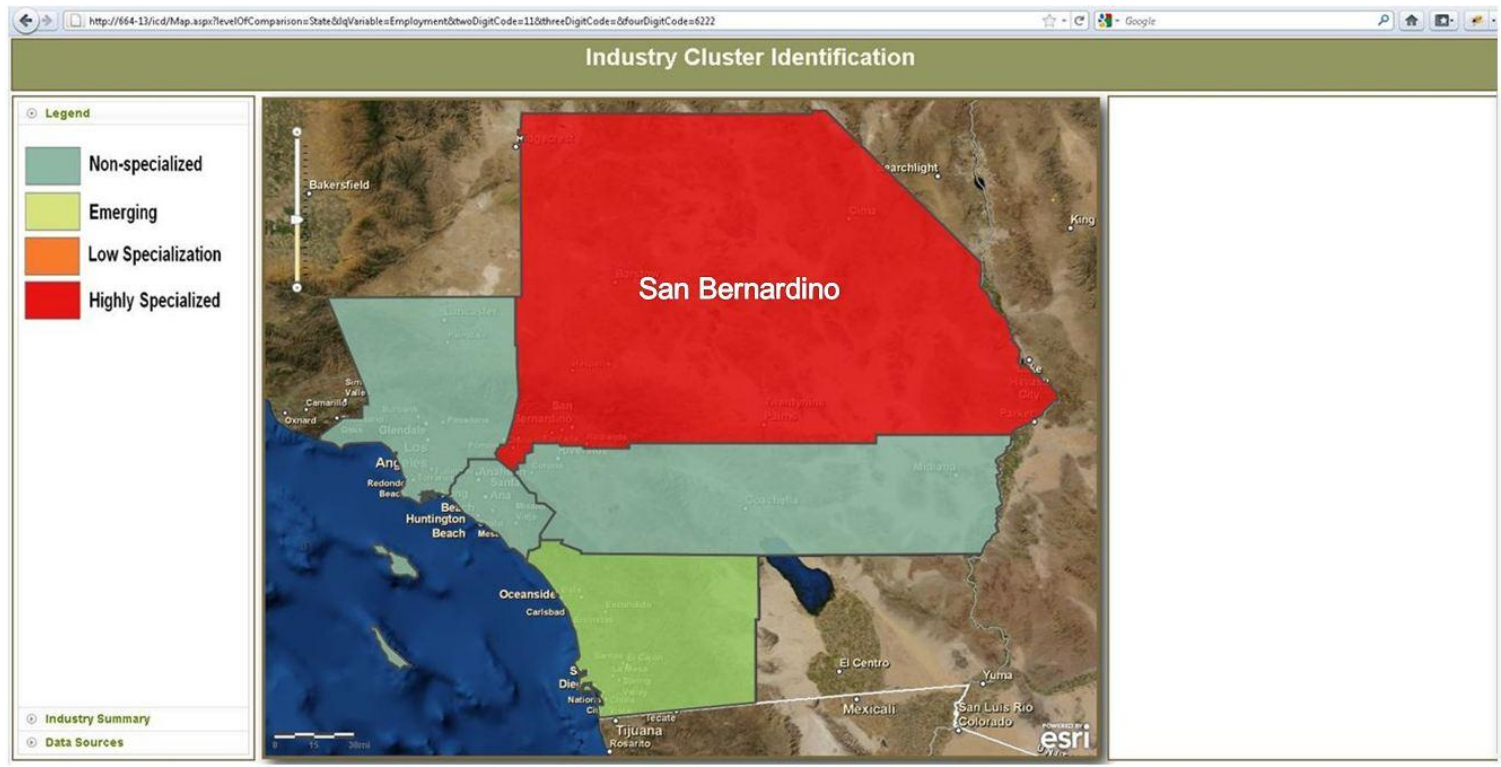

Figure 6-10: County/State Employment, NAICS 6222- Psychiatric and Substance Abuse Hospitals

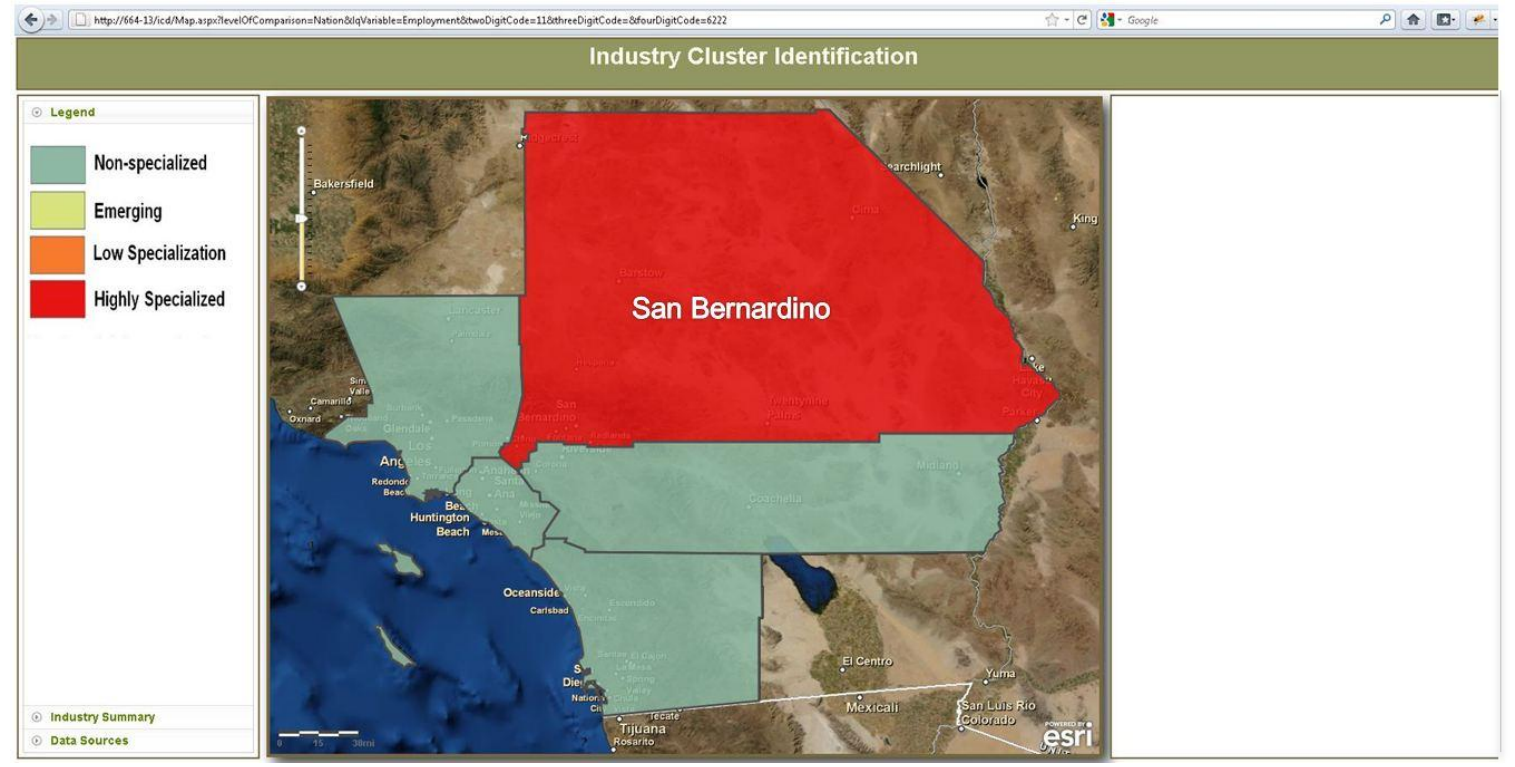

Figure 6-11: County/Nation Employment, NAICS 6222- Psychiatric and Substance Abuse Hospitals 
Although the choropleth maps in both figures can provide a user with a general level of specialization of a specific industry sector/sub-sector/group, the numerical value of the LQ is sometimes required for the user to understand the degree of specialization. To find this information, the identify function can be used show all the industries and LQ values for each county. For example, the user can click on San Bernardino in the Web application and scroll through the right panel to find the value associated with NAICS code 6222 (Figure 6-12).

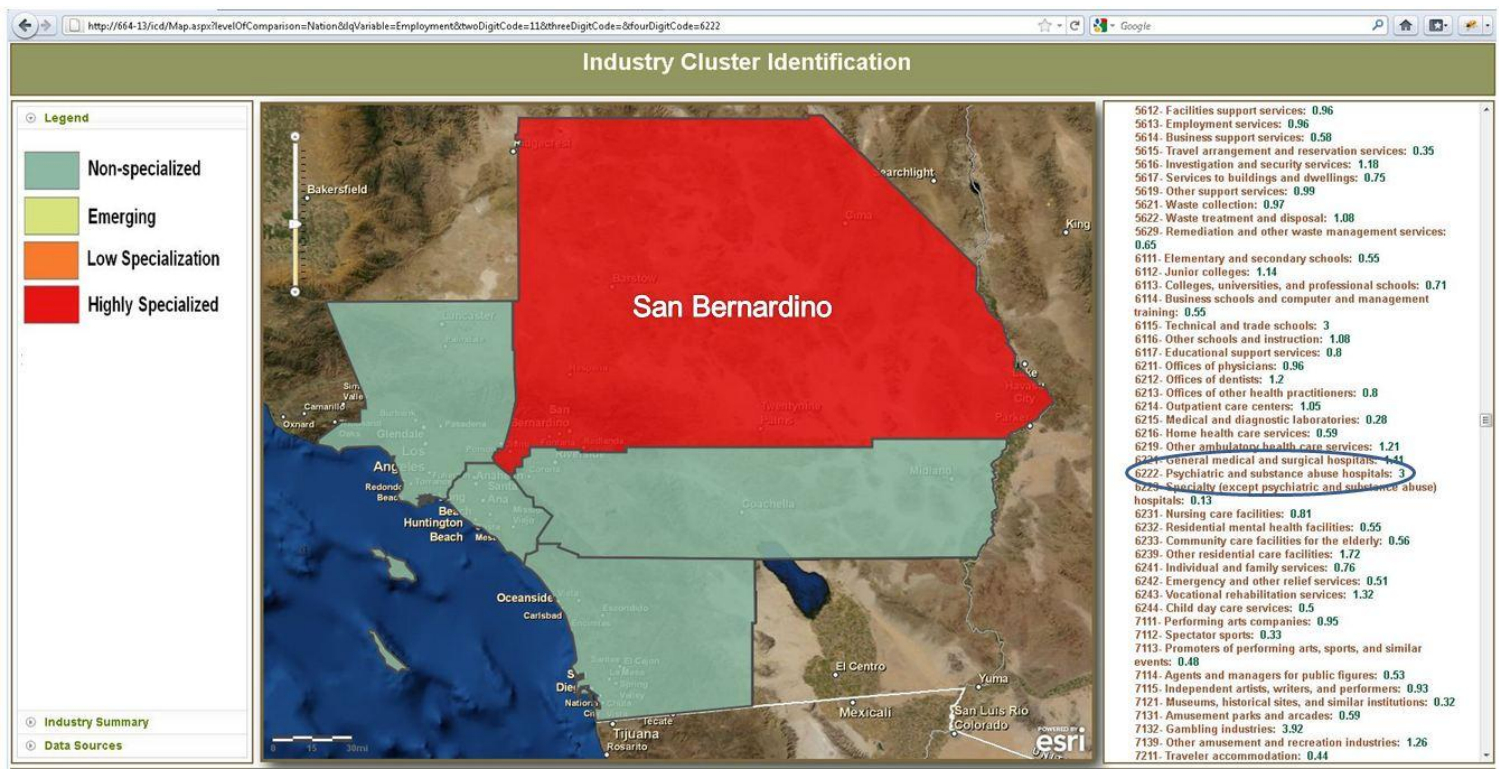

Figure 6-12: County/Nation Employment, NAICS 6222, Identify

The national LQ value is 3 for psychiatric and substance abuse hospitals, which indicates that this industry is three times more specialized than the nation in this region. Some caution should be taken when evaluating LQ values. The absolute employment values can be deceptive to industry specialization. For example, there may be occasions when the employment numbers used in the LQ calculation are low despite the indication the industry is specialized for the area. The determination that an industry is specialized base on LQ values can make sense for large employment groups but not necessarily for small employment groups and may not be an indication of growth potential. Also, because of the aggregation of industries a high LQ value for a four digit industry group may not necessarily translate to a high LQ value for a two digit industry sector. Figures 6-13 and 6-14 show the results for the third and last industry group - specialty hospitals (NAICS 6223). There is no specialization for San Bernardino County for this industry group for either comparison. Furthermore, only one of the surrounding counties shows low specialization on the county/state LQ value. 


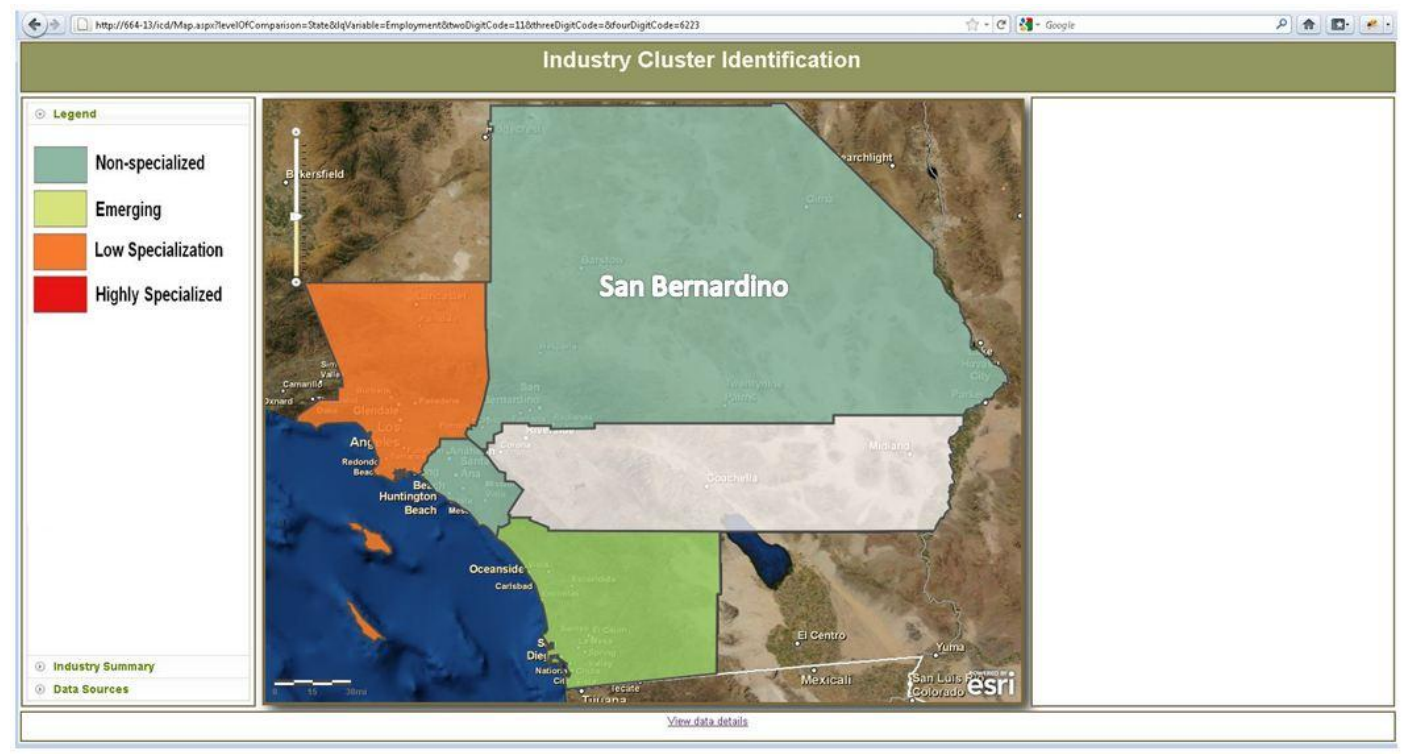

Figure 6-13: County/State Employment, NAICS 6223- Specialty Hospitals

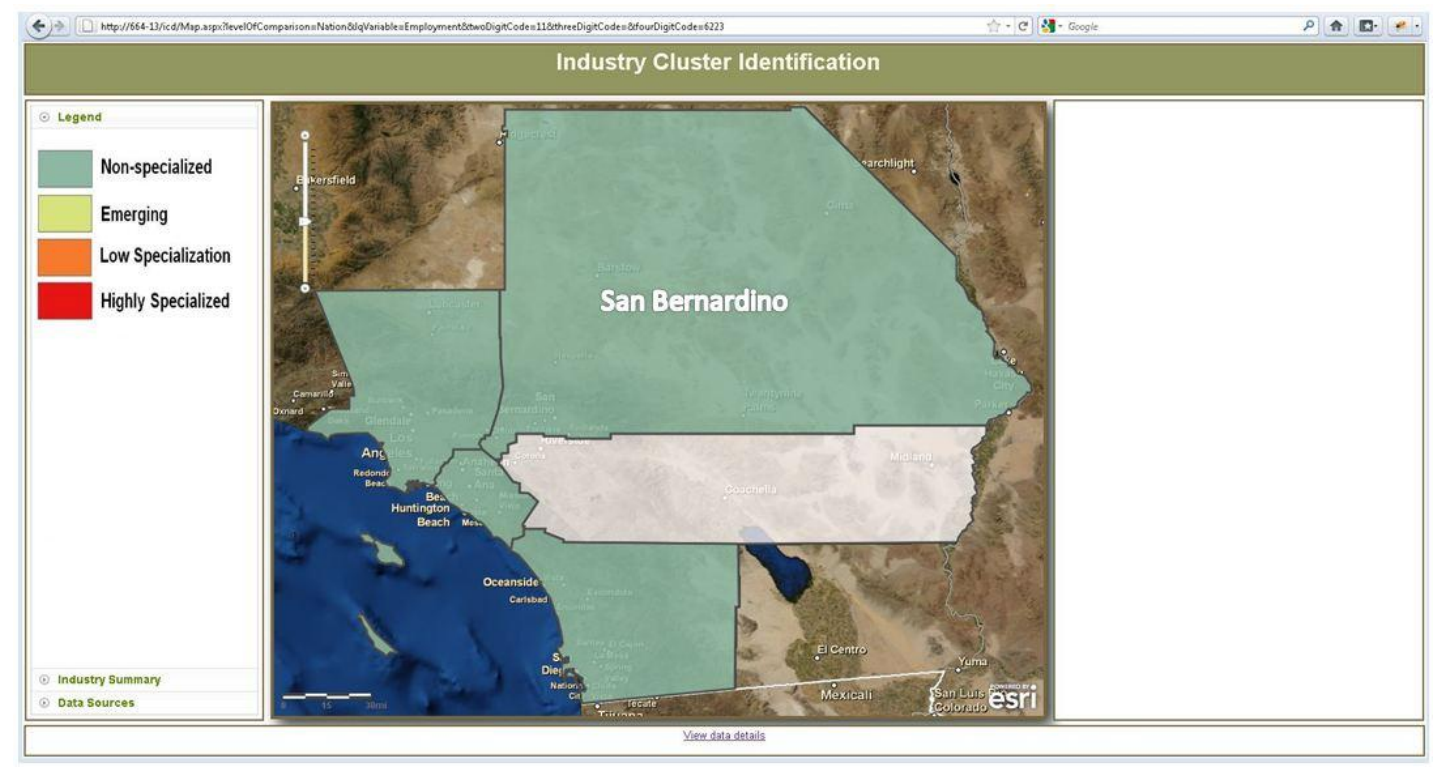

\section{Figure 6-14: County/Nation Employment, NAICS 6223- Specialty Hospitals}

Based on these results, a new training program aimed at supporting the hospital industry cluster seems appropriate for San Bernardino County. Because there is a high specialization for psychiatric and substance abuse hospitals attention should be given to this specific industry. To generate a list of potential schools that could implement a new program, a selection model was used on the IndustryEmploymentZipCode and EducationalFacilities layers available in the Web application. Figure 6-15 shows the model implemented in ArcGIS desktop 10.1. 


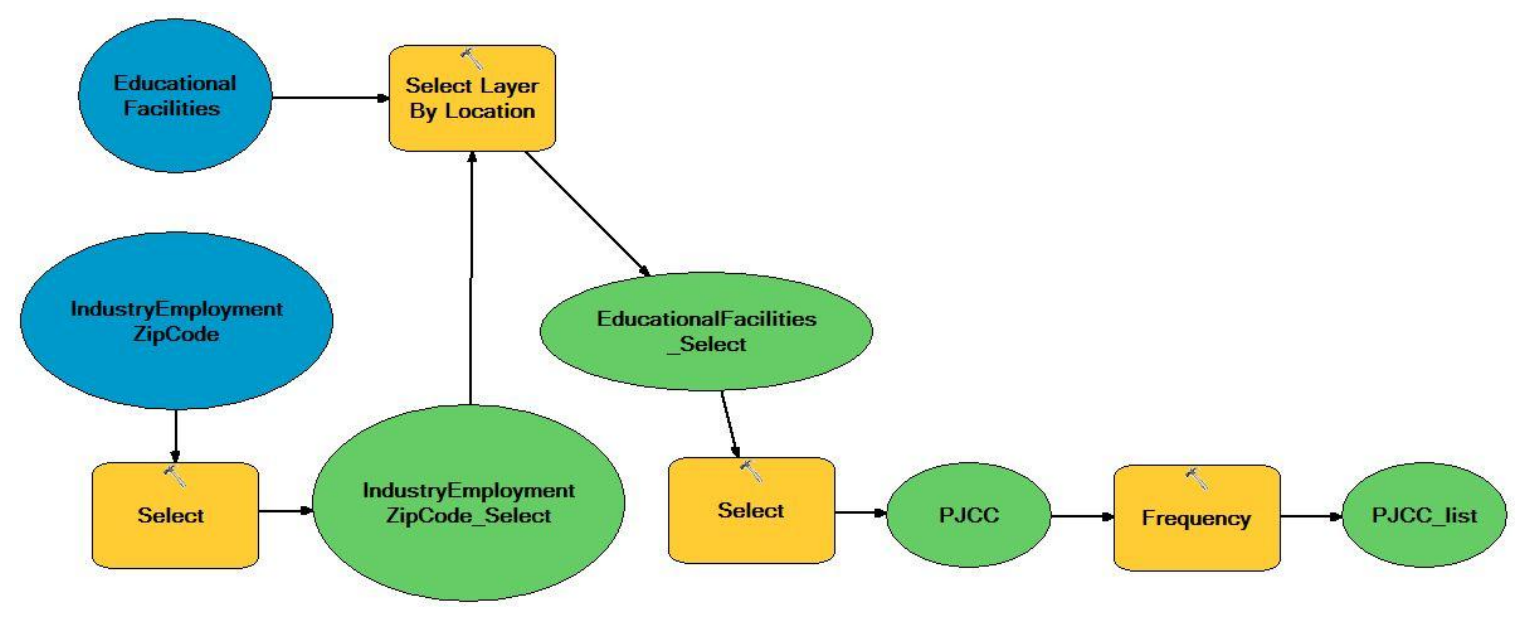

Figure 6-15: Model to select potential educational facilities

First, to support the hospital cluster (psychiatric and substance abuse hospitals in particular), programs should be made available to populations that make up the volume of the workforce for the industry. This number used was based on a median value of employees working in the healthcare industry. Second, the select layer by location tool was used to identify educational facilities within these areas. The select analysis tool was again utilized to find facilities with NAICS codes of 6112 and 6113 (junior colleges and colleges/universities, respectively). The output feature class, PJCC, was added to the display. Point features in this layer may include multiple facilities associated with a particular institution. Therefore, the final process of this analysis used the frequency tool to eliminate redundancy in the output table, PJCC_list. Figure 6-16 shows the results of the inquiry. 

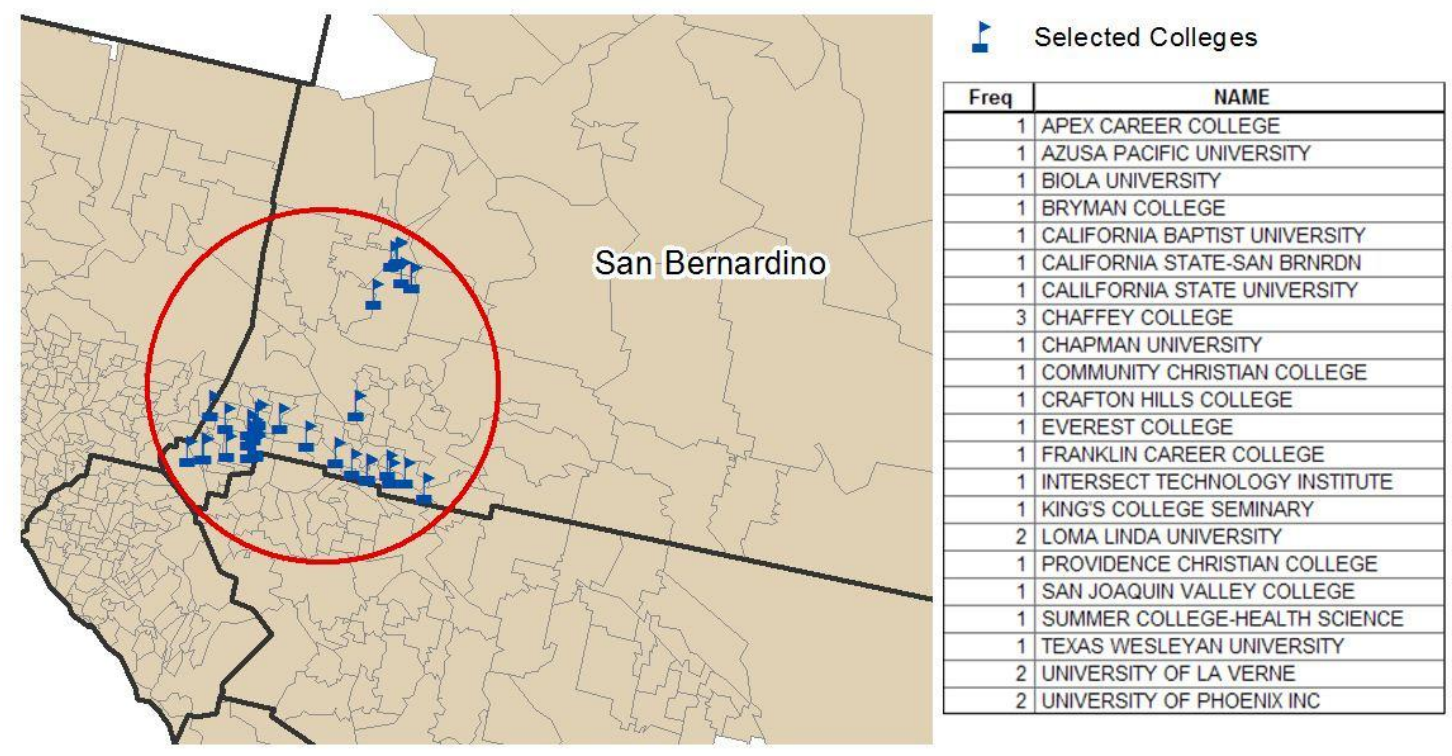

Figure 6-16: Selected Colleges

From this list, Chaffey College, Crafton Hills College, and San Joaquin Valley College seem to be appropriate schools for the new program, because none of these campuses currently offer programs that would support the psychiatric and substance abuse hospital cluster for San Bernardino County.

\subsection{Summary:}

Identifying specialized industries is the first step toward developing polices that aim to support clusters within an area. This chapter illustrates how the Industry Specialization Identification Web Application may be used to guide such policies. The development of an educational program intended to support the hospital industry cluster (psychiatric and substance abuse hospitals, in particular) for San Bernardino County was the main focus of this chapter. In addition to the Web application, additional analysis using the accompanying data layers provided the user with a list of potential facilities that could implement the new program. The following chapter will discuss the conclusions of the project and future work. 


\section{Chapter 7 - Conclusions and Future Work}

The demonstration model developed for this project to identify industry clusters using a Web application was achieved. In contrast to cluster studies which focused on a single or few industries at a time, this mode expanded the ability of economic planners to evaluate a wide range of industries. The traditional use of employment and comparison of county/nation was also increased to include establishment data and a county/state comparison. The client's requirement to develop a Web application was satisfied by using ArcGIS Javascript API to display location quotient (LQ) values in a meaningful way. This display diverges from the tabular form from which LQ values are usually assessed.

The main objective when considering the future development of this project would be expanding the geographic area of interest to include LQ data for the more than 3,000 US counties. A general application of this magnitude would provide a standardized way to evaluate clusters for a wide-spectrum of public and private entities. The disadvantage is that it could not provide detailed information on linkages within and between clusters. This type of analysis may outside the scope of any general Web application because it would most likely require proprietary data on individual business and the elicitation of local economic experts.

The geodatabase provided to the client contains additional layers of interest for community and economic planners and also serves as the basis for future development. For those interested in industry cluster analysis, a smaller geographic unit of measurement would be important to local development. For example, incorporating industry employment at the zip code level into the Web application and providing a zipcode look-up tool or city search tool would allow planners to evaluate how their area participates in a cluster. Pop-up reports and other diagrams could be included here.

For workforce development, measuring the local level of educational attainment and proximity to training facilities would give policy makers the opportunity to direct limited resources toward programs that support clusters. Drive-time analytical tools would be useful here as well as data collection on currently offered programs.

Tracking cluster changes over time would be the most beneficial development for this project. The data used here is based on the 2008 calendar year. Most however, are aware significant changes to the economy have taken place since this time. While economists and others use past information and trends to try and determine the direction of things to come, but singular years of economic data do not constitute trends. They are merely snapshots of what has already occurred. Though the public data used in this project (County Business Patterns) is only made available every five years, it would be valuable to incorporate new sets of data as they become available. 



\section{Works Cited}

Anselin, L.(1995). Local Indicators of Spatial Association-LISA. Geographical Analysis, Vol. 27, No.2. Retrieved from http://www.drs.wisc.edu/documents/articles/curtis/cesoc977/Anselin1995.pdf

Bergman, E.M., Feser, E.J. (1999). Industry Clusters: A Methodology and Framework for Regional Development Policy in the United States. OECD Proceedings; Boosting Innovation, The Cluster Approach. Retrieved from http://www.dpt.gov.tr/bgyu/abbp/italya/docs/6.Toolbox/13.Supporting_document s/1.Cluster_methodologies_casoni/4.Learning_materials_2/1.Cluster_analysis.pdf

Bureau of Labor Statistics. (2011). http://www.bls.gov/help/def/lq.htm

Bose, R. (2002). A Model for Location Analysis of Industries. Paper presented at ESRI International User Conference, 2002. Retrieved from http://proceedings.esri.com/library/userconf/proc02/pap0449/p0449.htm

Esri. (2011a). http://www.esri.com/software/arcgis/extensions/businessanalyst/dataus.html

Esri. (2011b). http://help.arcgis.com

Feser, E.J. (2001). Introduction to Regional Industry Cluster Analysis. Department of City \& Regional Planning, University of North Carolina at Chapel Hill. Lecture. Retrieved from http://www.csiss.org/learning_resources/content/papers/intro_to_clusters.pdf 
Fleming, K. (2008). Transportation and Warehouse Occupations, San Bernardino and Riverside Counties. Centers of Excellence. Retrieved from http://pdc.sbccd.cc.ca.us/Docs/ES_Reports/Trans\&Warehouse_Report_SBVC_09 2008.pdf

Frizado, J., Smith, B., Carroll, M. (2007). Identification of Economic Clusters Using ArcGIS Spatial Statistics. Paper presented at ESRI International User Conference, 2007. Retrieved from http://proceedings.esri.com/library/userconf/proc07/papers/papers/pap_1367.pdf

Galloway, H., Robison, H. (2008). Identification of Knowledge and Innovation Clusters: A GIS Application of Concentration, Co-existence, and Correlation. Economic Modeling Specialists, Inc. Retrieved from http://www.economicmodeling.com/wp-content/uploads/2008/08/wp_pnrec2008innovationclusters.pdf

Greene, R., Platt, J. (2009). A GIS Analysis of the Inland Empire's Business Geography: Focus on Small Business Dynamics. School of Business, University of Redlands. Retrieved from http://business.redlands.edu/grant/materials/A\%20GIS\%20Analysis\%20of\%20the \%20Inland\%20Empire\%20(22August09).pdf

Henton, D., Grose, T. (2007). California Regional Economies Project, Industry Clusters of Opportunity User Guide. California Economic Strategy Panel. Retrieved from http://www.coecon.com/Reports/ECONOMY/ClustersGuide.pdf 
Kelton, C.M.L., Pasquale, M.K., Rebelein, R.P. (2007). Using NAICS to Identify National Industry Cluster Templates for Applied Regional Analysis. Vasser College Economics Working Paper \#88. Retrieved from http://irving.vassar.edu/VCEWP/VCEWP88.pdf

Maimberg, A., Solvell, O., Zander, I. (1996). Spatial Clustering, Local Accumulation of Knowledge and Firm Competitiveness. Geografiska Annaler. Series B, Human Geography, Vol. 78, No. 2. Retrieved from http://www.jstor.org/stable/490807

Mills, Karen G., Reynolds, Elisabeth B., Reamer, Andrew. (2008). Clusters and Competitiveness: A New Federal Role for Stimulating Regional Economies. Metropolitan Policy Program at Brookings. Retrieved from http://www.brookings.edu/ /media/Files/rc/papers/2008/04_competitiveness_rea mer/Clusters\%20Brief.pdf

Muro, M., Katz, B. (2010). The New 'Cluster Moment': How Regional Innovation Clusters Can Foster The Next Economy. Metropolitan Policy Program at Brookings. Retrieved from http://www.brookings.edu/ /media/Files/rc/papers/2010/0921_clusters_muro_kat z/0921_clusters_muro_katz.pdf

Nacker, R. M. (2004). Evaluation of Forest Products Industry Cluster in Wisconsin and Recommendations for Economic Development Actions. (Project No.: 03-DG11244225-478). Retrieved from Wisconsin Economic Development Institute, Inc. website http://www.wi-edi.org/docs/ForestryClusterPaper.pdf 
Nolan, C., Kumar, I. (2006). Geographic Information Systems (GIS) in Business and Industry Cluster Analysis: A Case Study of Indiana. Paper presented at ESRI International User Conference, 2006. Retrieved from http://proceedings.esri.com/library/userconf/proc06/papers/papers/pap_2044.pdf

Porter, Michael E. (1998). Clusters and the New Economics of Competition. Harvard Business Review. Retrieved from http://im.univie.ac.at/fileadmin/user_upload/proj_windsperger/KFK/KfK/ClusterS trategy.pdf

Porter, M. E. (2000). Location, Competition, and Economic Development: Local Clusters in a Global Economy. Economic Development Quartely. Retrieved from home.furb.br/wilhelm/COMPETIV/Porter_Cluster3.doc

Pogodzinski, J.M., Kos, R.M. (2008). GIS Application. Chapter 2. Retrieved from http://www.pogodzinski.net/LED/JMPRMK_110608_Ch2_v1.pdf

Reid, N., Carroll, M. C., Smith, B. W. (2007). Critical Steps in the Cluster Building Process. The Economic Development Journal. Retrieved from http://uac.utoledo.edu/nwoerc/IEDC_EDJ_Reid.pdf

Sarkar, A. (2009). Identification and Spatial analysis of logistics hubs in Southern California. School of Business, University of Redlands. Retrieved from http://business.redlands.edu/grant/materials/Spatial\%20Analysis\%20of\%20Logist ics\%20Hubs.pdf

U.S. Census Bureau. (2011a). http://www.census.gov/eos/www/naics/

U.S. Census Bureau. (2011b). http://www.census.gov/econ/cbp/overview.htm 
U.S. Economic Development Administration, Center for Regional Development, Purdue University, Indiana Business Research Center, Kelley School of Business, Indiana University. Unlocking Rural Competitiveness; The Role of Regional Clusters. (2007). Retrieved from http://www.statsamerica.org/innovation/reports/unlocking_rural_competitiveness _full_report.pdf

Varga, A. (1998). Local Academic Knowledge Spillovers and the Concentration of Economic Activity. (Research Paper 9803). Retrieved from http://rri.wvu.edu/pdffiles/expansic13.pdf

vom Hofe, R., Chen, K. (2006). Whither or Not Industrial Cluster: Conclusions or Confusions. The Industrial Geographer, Volume 4, issue 1, 2006. Retrieved from http://igeographer.lib.indstate.edu/vom\%20Hofe.pdf w3cshools.com. (2011). http://www.w3schools.com

Worboys, M.F. (1997). GIS; A Computing Perspective. London, England: Taylor \&Francis.

Zhang, S., Guldmann, J. (2006). Estimating Suppressed Data in Regional Economic Databases: A Goal-Programming Approach. Department of City and Regional Planning, Ohio State University. Retrieved from http://knowlton.osu.edu/files/documents/JMG_WP_7.pdf 


\section{Appendix A. Industry Summary Tables}

Table A-1: Top Five Location Quotient Values for each County and Variable

Top 5 Location Quotient Values for each County and Variable

STEST $=$ county/state establishment

USEST $=$ county/nation establishment

STEMP = county/state employment

USEMP = county/nation employment

\begin{tabular}{|c|c|c|c|c|}
\hline \multirow[t]{16}{*}{ Los Angeles County } & & NAICS code & Description & STEST \\
\hline & Sector & 71 & Arts, entertainment, and recreation & 2.01 \\
\hline & & 31 & Manufacturing & 1.7 \\
\hline & & 51 & Information & 1.52 \\
\hline & & 42 & Wholesale trade & 1.37 \\
\hline & & 48 & Transportation and warehousing & 1.09 \\
\hline & Sub-Sector & 315 & Apparel manufacturing & 2.79 \\
\hline & & 711 & Performing arts, spectator sports, and related industries & 2.71 \\
\hline & & 512 & Motion picture and sound recording industries & 2.7 \\
\hline & & 313 & Textile mills & 2.43 \\
\hline & & 314 & Textile product mills & 1.87 \\
\hline & Industry Group & 7115 & Independent artists, writers, and performers & 3.03 \\
\hline & & 7114 & Agents and managers for public figures & 2.84 \\
\hline & & 3152 & Cut and sew apparel manufacturing & 2.82 \\
\hline & & 5121 & Motion picture and video industries & 2.72 \\
\hline & & 3132 & Fabric mills & 2.61 \\
\hline
\end{tabular}

\begin{tabular}{|c|c|c|c|c|}
\hline \multirow[t]{16}{*}{ Los Angeles County } & & NAICS code & Description & USEST \\
\hline & Sector & 31 & Manufacturing & 2.88 \\
\hline & & 71 & Arts, entertainment, and recreation & 2.8 \\
\hline & & 51 & Information & 1.96 \\
\hline & & 42 & Wholesale trade & 1.67 \\
\hline & & 33 & Manufacturing & 1.19 \\
\hline & Sub-Sector & 315 & Apparel manufacturing & 10.2 \\
\hline & & 512 & Motion picture and sound recording industries & 7.05 \\
\hline & & 711 & Performing arts, spectator sports, and related industries & 6.86 \\
\hline & & 313 & Textile mills & 2.87 \\
\hline & & 314 & Textile product mills & 2.64 \\
\hline & Industry Group & 3152 & Cut and sew apparel manufacturing & 11.5 \\
\hline & & 7115 & Independent artists, writers, and performers & 11.27 \\
\hline & & 7114 & Agents and managers for public figures & 7.57 \\
\hline & & 5121 & Motion picture and video industries & 7.36 \\
\hline & & 4243 & Apparel, piece goods, and notions merchant wholesalers & 6.61 \\
\hline
\end{tabular}

\begin{tabular}{|c|c|c|c|c|}
\hline \multirow[t]{16}{*}{ Los Angeles County } & & NAICS code & Description & STEMP \\
\hline & Sector & 31 & Manufacturing & 1.53 \\
\hline & & 51 & Information & 1.44 \\
\hline & & 48 & Transportation and warehousing & 1.37 \\
\hline & & 61 & Educational services & 1.3 \\
\hline & & 42 & Wholesale trade & 1.11 \\
\hline & Sub-Sector & 512 & Motion picture and sound recording industries & 2.97 \\
\hline & & 315 & Apparel manufacturing & 2.86 \\
\hline & & 313 & Textile mills & 2.73 \\
\hline & & 316 & Leather and allied product manufacturing & 2.24 \\
\hline & & 314 & Textile product mills & 2.2 \\
\hline & Industry Group & 7114 & Agents and managers for public figures & 3.12 \\
\hline & & 5152 & Cable and other subscription programming & 3.03 \\
\hline & & 5121 & Motion picture and video industries & 2.97 \\
\hline & & 5122 & Sound recording industries & 2.96 \\
\hline & & 3132 & Fabric mills & 2.92 \\
\hline
\end{tabular}




\begin{tabular}{|c|c|c|c|c|}
\hline \multirow[t]{16}{*}{ Los Angeles County } & & NAICS code & Description & USEMP \\
\hline & Sector & 51 & Information & 2.05 \\
\hline & & 31 & Manufacturing & 1.88 \\
\hline & & 42 & Wholesale trade & 1.41 \\
\hline & & 54 & Professional, scientific, and technical services & 1.41 \\
\hline & & 71 & Arts, entertainment, and recreation & 1.28 \\
\hline & Sub-Sector & 512 & Motion picture and sound recording industries & 11.73 \\
\hline & & 315 & Apparel manufacturing & 10.18 \\
\hline & & 711 & Performing arts, spectator sports, and related industries & 2.64 \\
\hline & & 316 & Leather and allied product manufacturing & 2.57 \\
\hline & & 488 & Support activities for transportation & 2.55 \\
\hline & Industry Group & 3152 & Cut and sew apparel manufacturing & 12.16 \\
\hline & & 5121 & Motion picture and video industries & 12.04 \\
\hline & & 7114 & Agents and managers for public figures & 10.56 \\
\hline & & 7115 & Independent artists, writers, and performers & 8.83 \\
\hline & & 5122 & Sound recording industries & 7.47 \\
\hline
\end{tabular}

\begin{tabular}{|c|c|c|c|c|}
\hline \multirow[t]{17}{*}{ Orange County } & & NAICS code & Description & STEST \\
\hline & Sector & 55 & Management of companies and enterprises & 1.38 \\
\hline & & 52 & Finance and insurance & 1.25 \\
\hline & & 42 & Wholesale trade & 1.23 \\
\hline & & 54 & Professional, scientific, and technical services & 1.23 \\
\hline & & 32 & Manufacturing & 1.2 \\
\hline & Sub-Sector & 525 & Funds, trusts, and other financial vehicles & 2.02 \\
\hline & & 533 & Lessors of nonfinancial intangible assets & 1.75 \\
\hline & & 425 & Wholesale electronic markets and agents and brokers & 1.7 \\
\hline & & 336 & Transportation equipment manufacturing & 1.65 \\
\hline & & 334 & Computer and electronic product manufacturing & 1.51 \\
\hline & & & & \\
\hline & Industry Group & 3122 & Tobacco manufacturing & 4.91 \\
\hline & & 5259 & Other investment pools and funds & 2.02 \\
\hline & & 3364 & Aerospace product and parts manufacturing & 1.95 \\
\hline & & 3322 & Cutlery and handtool manufacturing & 1.84 \\
\hline & & 3363 & Motor vehicle parts manufacturing & 1.8 \\
\hline
\end{tabular}

\begin{tabular}{|c|c|c|c|c|}
\hline \multirow[t]{16}{*}{ Orange County } & & NAICS code & Description & USEST \\
\hline & Sector & 42 & Wholesale trade & 1.51 \\
\hline & & 54 & Professional, scientific, and technical services & 1.41 \\
\hline & & 31 & Manufacturing & 1.28 \\
\hline & & 53 & Real estate and rental and leasing & 1.19 \\
\hline & & 55 & Management of companies and enterprises & 1.14 \\
\hline & Sub-Sector & 525 & Funds, trusts, and other financial vehicles & 4.01 \\
\hline & & 334 & Computer and electronic product manufacturing & 3.05 \\
\hline & & 315 & Apparel manufacturing & 2.63 \\
\hline & & 314 & Textile product mills & 1.89 \\
\hline & & 335 & Electrical equipment, appliance, and component manufacturing & 1.81 \\
\hline & Industry Group & 3344 & Semiconductor and other electronic component manufacturing & 4.19 \\
\hline & & 5259 & Other investment pools and funds & 4.01 \\
\hline & & 3341 & Computer and peripheral equipment manufacturing & 3.91 \\
\hline & & 3369 & Other transportation equipment manufacturing & 3.41 \\
\hline & & 3364 & Aerospace product and parts manufacturing & 3.02 \\
\hline
\end{tabular}

\begin{tabular}{|c|c|c|c|c|}
\hline \multirow[t]{16}{*}{ Orange County } & & NAICS code & Description & STEMP \\
\hline & Sector & 52 & Finance and insurance & 1.36 \\
\hline & & 53 & Real estate and rental and leasing & 1.31 \\
\hline & & 42 & Wholesale trade & 1.26 \\
\hline & & 55 & Management of companies and enterprises & 1.26 \\
\hline & & 53 & Real estate and rental and leasing & 1.25 \\
\hline & Sub-Sector & 339 & Miscellaneous manufacturing & 2.31 \\
\hline & & 525 & Funds, trusts, and other financial vehicles & 2.3 \\
\hline & & 425 & Wholesale electronic markets and agents and brokers & 2.15 \\
\hline & & 335 & Electrical equipment, appliance, and component manufacturing & 1.76 \\
\hline & & 533 & Lessors of nonfinancial intangible assets & 1.67 \\
\hline & Industry Group & 3122 & Tobacco manufacturing & 7.6 \\
\hline & & 7131 & Amusement parks and arcades & 4.79 \\
\hline & & 2372 & Land subdivision & 3.75 \\
\hline & & 4862 & Pipeline transportation of natural gas & 3.02 \\
\hline & & 3391 & Medical equipment and supplies manufacturing & 2.91 \\
\hline
\end{tabular}




\begin{tabular}{|c|c|c|c|c|}
\hline \multirow[t]{17}{*}{ Orange County } & & NAICS code & Description & USEMP \\
\hline & Sector & 53 & Real estate and rental and leasing & 1.6 \\
\hline & & 42 & Wholesale trade & 1.59 \\
\hline & & 71 & Arts, entertainment, and recreation & 1.49 \\
\hline & & 23 & Construction & 1.29 \\
\hline & & 54 & Professional, scientific, and technical services & 1.25 \\
\hline & Sub-Sector & 525 & Funds, trusts, and other financial vehicles & 4.71 \\
\hline & & 339 & Miscellaneous manufacturing & 3.06 \\
\hline & & 334 & Computer and electronic product manufacturing & 2.73 \\
\hline & & 315 & Apparel manufacturing & 2.65 \\
\hline & & 425 & Wholesale electronic markets and agents and brokers & 2.39 \\
\hline & & & & \\
\hline & Industry Group & 7131 & Amusement parks and arcades & 10.97 \\
\hline & & 3342 & Communications equipment manufacturing & 6.62 \\
\hline & & 2372 & Land subdivision & 6.03 \\
\hline & & 5259 & Other investment pools and funds & 4.71 \\
\hline & & 3391 & Medical equipment and supplies manufacturing & 4.57 \\
\hline
\end{tabular}

\begin{tabular}{|c|c|c|c|c|}
\hline \multirow[t]{17}{*}{ Riverside } & & NAICS code & Description & STEST \\
\hline & Sector & 23 & Construction & 1.46 \\
\hline & & 48 & Transportation and warehousing & 1.24 \\
\hline & & 22 & Utilities & 1.22 \\
\hline & & 44 & Retail trade & 1.2 \\
\hline & & 56 & Administrative and Support and Waste Mang and Remediation Srvs & 1.19 \\
\hline & Sub-sector & 237 & Heavy and civil engineering construction & 1.89 \\
\hline & & 336 & Transportation equipment manufacturing & 1.76 \\
\hline & & 212 & Mining (except oil and gas) & 1.73 \\
\hline & & 238 & Specialty trade contractors & 1.62 \\
\hline & & 321 & Wood product manufacturing & 1.55 \\
\hline & & & & \\
\hline & Industry Group & 2121 & Coal mining & 12.50 \\
\hline & & 3362 & Motor vehicle body and trailer manufacturing & 3.38 \\
\hline & & 3325 & Hardware manufacturing & 2.86 \\
\hline & & 2379 & Other heavy and civil engineering construction & 2.59 \\
\hline & & 3212 & Veneer, plywood, and engineered wood product manufacturing & 2.41 \\
\hline
\end{tabular}

\begin{tabular}{|c|c|c|c|c|}
\hline \multirow[t]{16}{*}{ Riverside } & & NAICS code & Description & USEST \\
\hline & Sector & 23 & Construction & 1.27 \\
\hline & & 53 & Real estate and rental and leasing & 1.2 \\
\hline & & 56 & Administrative and Support and Waste Mang and Remediation Srvs & 1.13 \\
\hline & & 72 & Accommodation and food services & 1.13 \\
\hline & & 62 & Health care and social assistance & 1.05 \\
\hline & Sub-sector & 336 & Transportation equipment manufacturing & 1.84 \\
\hline & & 525 & Funds, trusts, and other financial vehicles & 1.55 \\
\hline & & 237 & Heavy and civil engineering construction & 1.4 \\
\hline & & 115 & Support activities for agriculture and forestry & 1.38 \\
\hline & & 238 & Specialty trade contractors & 1.37 \\
\hline & Industry Group & 3369 & Other transportation equipment manufacturing & 4.74 \\
\hline & & 3325 & Hardware manufacturing & 3.51 \\
\hline & & 3362 & Motor vehicle body and trailer manufacturing & 2.81 \\
\hline & & 4884 & Support activities for road transportation & 2.44 \\
\hline & & 6239 & Other residential care facilities & 2.15 \\
\hline
\end{tabular}

\begin{tabular}{|c|c|c|c|c|}
\hline \multirow[t]{16}{*}{ Riverside } & & NAICS code & Description & STEMP \\
\hline & Sector & 23 & Construction & 1.9 \\
\hline & & 71 & Arts, entertainment, and recreation & 1.43 \\
\hline & & 32 & Manufacturing & 1.41 \\
\hline & & 72 & Accommodation and food services & 1.37 \\
\hline & & 44 & Retail trade & 1.35 \\
\hline & Sub-sector & 493 & Warehousing and storage & 3.05 \\
\hline & & 321 & Wood product manufacturing & 2.61 \\
\hline & & 237 & Heavy and civil engineering construction & 2.5 \\
\hline & & 721 & Accommodation & 2.13 \\
\hline & & 326 & Plastics and rubber products manufacturing & 2.1 \\
\hline & Industry Group & 3362 & Motor vehicle body and trailer manufacturing & 10.28 \\
\hline & & 2121 & Coal mining & 8.64 \\
\hline & & 4882 & Support activities for rail transportation & 4.18 \\
\hline & & 3271 & Clay product and refractory manufacturing & 3.92 \\
\hline & & 3379 & Other furniture related product manufacturing & 3.78 \\
\hline
\end{tabular}




\begin{tabular}{|c|c|c|c|c|}
\hline \multirow[t]{16}{*}{ Riverside } & & NAICS code & Description & USEMP \\
\hline & Sector & 23 & Construction & 2 \\
\hline & & 71 & Arts, entertainment, and recreation & 1.85 \\
\hline & & 72 & Accommodation and food services & 1.43 \\
\hline & & 44 & Retail trade & 1.3 \\
\hline & & 53 & Real estate and rental and leasing & 1.28 \\
\hline & Sub-sector & 493 & Warehousing and storage & 2.99 \\
\hline & & 339 & Miscellaneous manufacturing & 2.53 \\
\hline & & 713 & Amusement, gambling, and recreation industries & 2.35 \\
\hline & & 721 & Accommodation & 2.29 \\
\hline & & 238 & Specialty trade contractors & 2.23 \\
\hline & Industry Group & 7132 & Gambling industries & 6.24 \\
\hline & & 3362 & Motor vehicle body and trailer manufacturing & 6.11 \\
\hline & & 3379 & Other furniture related product manufacturing & 4.7 \\
\hline & & 4884 & Support activities for road transportation & 4.43 \\
\hline & & 2212 & Natural gas distribution & 4.31 \\
\hline
\end{tabular}

\begin{tabular}{|c|c|c|c|c|}
\hline \multirow[t]{17}{*}{ San Bernardino } & & NAICS code & Description & STEST \\
\hline & Sector & 22 & Utilities & 2.05 \\
\hline & & 48 & Transportation and warehousing & 1.7 \\
\hline & & 32 & Manufacturing & 1.55 \\
\hline & & 23 & Construction & 1.26 \\
\hline & & 44 & Retail trade & 1.21 \\
\hline & Sub-sector & 493 & Warehousing and storage & 3.78 \\
\hline & & 486 & Pipeline transportation & 3.09 \\
\hline & & 326 & Plastics and rubber products manufacturing & 2.65 \\
\hline & & 331 & Primary metal manufacturing & 2.46 \\
\hline & & 484 & Truck transportation & 2.1 \\
\hline & & & & \\
\hline & Industry Group & 2122 & Metal ore mining & 6.25 \\
\hline & & 4869 & Other pipeline transportation & 5.32 \\
\hline & & 3361 & Motor vehicle manufacturing & 4.98 \\
\hline & & 3311 & Iron and steel mills and ferroalloy manufacturing & 4.57 \\
\hline & & 3313 & Alumina and aluminum production and processing & 4.29 \\
\hline
\end{tabular}

\begin{tabular}{|c|c|c|c|c|}
\hline \multirow[t]{16}{*}{ San Bernardino } & & NAICS code & Description & USEST \\
\hline & Sector & 48 & Transportation and warehousing & 1.43 \\
\hline & & 32 & Manufacturing & 1.41 \\
\hline & & 42 & Wholesale trade & 1.36 \\
\hline & & 22 & Utilities & 1.15 \\
\hline & & 72 & Accommodation and food services & 1.12 \\
\hline & Sub-sector & 493 & Warehousing and storage & 3.97 \\
\hline & & 326 & Plastics and rubber products manufacturing & 2.52 \\
\hline & & 336 & Transportation equipment manufacturing & 2.32 \\
\hline & & 331 & Primary metal manufacturing & 2.09 \\
\hline & & 332 & Fabricated metal product manufacturing & 1.65 \\
\hline & Industry Group & 3361 & Motor vehicle manufacturing & 5.49 \\
\hline & & 3369 & Other transportation equipment manufacturing & 5.32 \\
\hline & & 4931 & Warehousing and storage & 3.97 \\
\hline & & 3313 & Alumina and aluminum production and processing & 3.87 \\
\hline & & 3311 & Iron and steel mills and ferroalloy manufacturing & 3.62 \\
\hline
\end{tabular}

\begin{tabular}{|c|c|c|c|c|}
\hline \multirow[t]{16}{*}{ San Bernardino } & & NAICS code & Description & STEMP \\
\hline & Sector & 48 & Transportation and warehousing & 1.92 \\
\hline & & 32 & Manufacturing & 1.64 \\
\hline & & 22 & Utilities & 1.57 \\
\hline & & 44 & Retail trade & 1.22 \\
\hline & & 49 & Transportation and warehousing & 1.2 \\
\hline & Sub-sector & 493 & Warehousing and storage & 4.67 \\
\hline & & 331 & Primary metal manufacturing & 3.89 \\
\hline & & 484 & Truck transportation & 3.68 \\
\hline & & 212 & Mining (except oil and gas) & 3.12 \\
\hline & & 327 & Nonmetallic mineral product manufacturing & 3.05 \\
\hline & Industry Group & 3311 & Iron and steel mills and ferroalloy manufacturing & 14.02 \\
\hline & & 2122 & Metal ore mining & 5.86 \\
\hline & & 3273 & Cement and concrete product manufacturing & 5.17 \\
\hline & & 3313 & Alumina and aluminum production and processing & 5.07 \\
\hline & & 4931 & Warehousing and storage & 4.67 \\
\hline
\end{tabular}




\begin{tabular}{|c|c|c|c|c|}
\hline \multirow[t]{16}{*}{ San Bernardino } & & NAICS code & Description & USEMP \\
\hline & Sector & 48 & Transportation and warehousing & 1.69 \\
\hline & & 42 & Wholesale trade & 1.3 \\
\hline & & 22 & Utilities & 1.26 \\
\hline & & 71 & Arts, entertainment, and recreation & 1.24 \\
\hline & & 23 & Construction & 1.23 \\
\hline & Sub-sector & 493 & Warehousing and storage & 4.59 \\
\hline & & 492 & Couriers and messengers & 2.92 \\
\hline & & 484 & Truck transportation & 2.61 \\
\hline & & 327 & Nonmetallic mineral product manufacturing & 2.59 \\
\hline & & 337 & Furniture and related product manufacturing & 2.28 \\
\hline & Industry Group & 3351 & Electric lighting equipment manufacturing & 4.74 \\
\hline & & 3273 & Cement and concrete product manufacturing & 4.63 \\
\hline & & 4931 & Warehousing and storage & 4.59 \\
\hline & & 7132 & Gambling industries & 3.92 \\
\hline & & 3346 & Manufacturing and reproducing magnetic and optical media & 3.92 \\
\hline
\end{tabular}

\begin{tabular}{|c|c|c|c|c|}
\hline \multirow[t]{17}{*}{ San Diego County } & & NAICS code & Description & STEST \\
\hline & Sector & 53 & Real estate and rental and leasing & 1.24 \\
\hline & & 54 & Professional, scientific, and technical services & 1.21 \\
\hline & & 56 & Administrative and Support and Waste Mang and Remediation Srvs & 1.11 \\
\hline & & 52 & Finance and insurance & 1.07 \\
\hline & & 23 & Construction & 1.05 \\
\hline & Sub-sector & 487 & Scenic and sightseeing transportation & 2.51 \\
\hline & & 114 & Fishing, hunting and trapping & 2.18 \\
\hline & & 483 & Water transportation & 1.48 \\
\hline & & 531 & Real estate & 1.28 \\
\hline & & 316 & Leather and allied product manufacturing & 1.27 \\
\hline & & & & \\
\hline & Industry Group & 4872 & Scenic and sightseeing transportation, water & 3.13 \\
\hline & & 3366 & Ship and boat building & 2.98 \\
\hline & & 4879 & Scenic and sightseeing transportation, other & 2.81 \\
\hline & & 1141 & Fishing & 2.52 \\
\hline & & 5417 & Scientific research and development services & 2.32 \\
\hline
\end{tabular}

\begin{tabular}{|c|c|c|c|c|}
\hline \multirow[t]{16}{*}{ San Diego County } & & NAICS code & Description & USEST \\
\hline & Sector & 53 & Real estate and rental and leasing & 1.41 \\
\hline & & 54 & Professional, scientific, and technical services & 1.39 \\
\hline & & 61 & Educational services & 1.18 \\
\hline & & 56 & Administrative and Support and Waste Mang and Remediation Srvs & 1.06 \\
\hline & & 42 & Wholesale trade & 1.02 \\
\hline & Sub-sector & 334 & Computer and electronic product manufacturing & 2.51 \\
\hline & & 487 & Scenic and sightseeing transportation & 2.25 \\
\hline & & 316 & Leather and allied product manufacturing & 1.55 \\
\hline & & 531 & Real estate & 1.52 \\
\hline & & 525 & Funds, trusts, and other financial vehicles & 1.5 \\
\hline & Industry Group & 5417 & Scientific research and development services & 4 \\
\hline & & 4879 & Scenic and sightseeing transportation, other & 3.42 \\
\hline & & 3254 & Pharmaceutical and medicine manufacturing & 3.18 \\
\hline & & 3369 & Other transportation equipment manufacturing & 3.08 \\
\hline & & 3343 & Audio and video equipment manufacturing & 2.99 \\
\hline
\end{tabular}

\begin{tabular}{|c|c|c|c|c|}
\hline \multirow[t]{16}{*}{ San Diego County } & & NAICS code & Description & STEMP \\
\hline & Sector & 71 & Arts, entertainment, and recreation & 1.27 \\
\hline & & 72 & Accommodation and food services & 1.22 \\
\hline & & 54 & Professional, scientific, and technical services & 1.19 \\
\hline & & 23 & Construction & 1.13 \\
\hline & & 22 & Utilities & 1.12 \\
\hline & Sub-sector & 712 & Museums, historical sites, and similar institutions & 2.88 \\
\hline & & 487 & Scenic and sightseeing transportation & 2.77 \\
\hline & & 721 & Accommodation & 1.81 \\
\hline & & 336 & Transportation equipment manufacturing & 1.64 \\
\hline & & 114 & Fishing, hunting and trapping & 1.6 \\
\hline & Industry Group & 3366 & Ship and boat building & 9.02 \\
\hline & & 3336 & Engine, turbine, and power transmission equipment manufacturing & 5.62 \\
\hline & & 4872 & Scenic and sightseeing transportation, water & 3.64 \\
\hline & & 4862 & Pipeline transportation of natural gas & 3.57 \\
\hline & & 7121 & Museums, historical sites, and similar institutions & 2.88 \\
\hline
\end{tabular}




\begin{tabular}{|c|c|c|c|c|}
\hline \multirow[t]{16}{*}{ San Diego County } & & NAICS code & Description & USEMP \\
\hline & Sector & 71 & Arts, entertainment, and recreation & 1.65 \\
\hline & & 54 & Professional, scientific, and technical services & 1.55 \\
\hline & & 53 & Real estate and rental and leasing & 1.53 \\
\hline & & 72 & Accommodation and food services & 1.27 \\
\hline & & 23 & Construction & 1.19 \\
\hline & Sub-sector & 487 & Scenic and sightseeing transportation & 3 \\
\hline & & 712 & Museums, historical sites, and similar institutions & 2.87 \\
\hline & & 721 & Accommodation & 1.95 \\
\hline & & 339 & Miscellaneous manufacturing & 1.87 \\
\hline & & 334 & Computer and electronic product manufacturing & 1.87 \\
\hline & Industry Group & 3366 & Ship and boat building & 5.86 \\
\hline & & 4872 & Scenic and sightseeing transportation, water & 5.57 \\
\hline & & 3336 & Engine, turbine, and power transmission equipment manufacturing & 4.13 \\
\hline & & 7132 & Gambling industries & 4.01 \\
\hline & & 7131 & Amusement parks and arcades & 3.74 \\
\hline
\end{tabular}

\section{Table A-2: All Specialized Industries by County}

Los Angeles County

\begin{tabular}{ccl} 
STEMP & 2007 NAICS code & Description \\
3.12 & 7114 & Agents and managers for public figures \\
3.03 & 5152 & Cable and other subscription programming \\
2.97 & 5121 & Motion picture and video industries \\
2.97 & 512 & Motion picture and sound recording industries \\
2.96 & 5122 & Sound recording industries \\
2.92 & 3132 & Fabric mills \\
2.89 & 3152 & Cut and sew apparel manufacturing \\
2.86 & 315 & Apparel manufacturing \\
2.80 & 4883 & Support activities for water transportation \\
2.79 & 3162 & Footwear manufacturing \\
2.74 & 3133 & Textile and fabric finishing and fabric coating mills \\
2.73 & 313 & Textile mills \\
2.72 & 7115 & Independent artists, writers, and performers \\
& & Soap, cleaning compound, and toilet preparation \\
2.47 & 3256 & manufacturing \\
2.37 & 3325 & Hardware manufacturing \\
2.35 & 3111 & Animal food manufacturing \\
2.35 & 3159 & Apparel accessories and other apparel manufacturing \\
2.30 & 4243 & Apparel, piece goods, and notions merchant wholesalers \\
2.26 & 3151 & Apparel knitting mills \\
2.24 & 316 & Leather and allied product manufacturing \\
2.24 & 3149 & Other textile product mills \\
2.21 & 3352 & Household appliance manufacturing \\
2.20 & 314 & Textile product mills \\
2.18 & 3161 & Leather and hide tanning and finishing \\
2.14 & 3141 & Textile furnishings mills \\
2.11 & 3117 & Seafood product preparation and packaging \\
& & \\
\hline
\end{tabular}




\begin{tabular}{|c|c|c|}
\hline 2.08 & 3169 & Other leather and allied product manufacturing \\
\hline 2.06 & 3312 & Steel product manufacturing from purchased steel \\
\hline 2.01 & 3314 & $\begin{array}{l}\text { Nonferrous metal (except aluminum) production and } \\
\text { processing }\end{array}$ \\
\hline 1.99 & 4831 & Deep sea, coastal, and great lakes water transportation \\
\hline 1.98 & 4882 & Support activities for rail transportation \\
\hline 1.94 & 515 & Broadcasting (except Internet) \\
\hline 1.89 & 4885 & Freight transportation arrangement \\
\hline 1.89 & 483 & Water transportation \\
\hline 1.88 & 488 & Support activities for transportation \\
\hline 1.84 & 711 & Performing arts, spectator sports, and related industries \\
\hline 1.82 & 3315 & Foundries \\
\hline 1.78 & 6223 & Specialty (except psychiatric and substance abuse) hospitals \\
\hline 1.75 & 3131 & Fiber, yarn, and thread mills \\
\hline 1.74 & 3259 & Other chemical product and preparation manufacturing \\
\hline 1.73 & 8129 & Other personal services \\
\hline 1.72 & 5151 & Radio and television broadcasting \\
\hline 1.70 & 533 & Lessors of nonfinancial intangible assets \\
\hline 1.70 & 5331 & Lessors of nonfinancial intangible assets \\
\hline 1.68 & 5412 & $\begin{array}{l}\text { Accounting, tax preparation, bookkeeping, and payroll } \\
\text { services }\end{array}$ \\
\hline 1.65 & 3321 & Forging and stamping \\
\hline 1.63 & 3364 & Aerospace product and parts manufacturing \\
\hline 1.62 & 4232 & Furniture and home furnishing merchant wholesalers \\
\hline 1.60 & 324 & Petroleum and coal products manufacturing \\
\hline 1.60 & 3241 & Petroleum and coal products manufacturing \\
\hline 1.60 & 331 & Primary metal manufacturing \\
\hline 1.59 & 4811 & Scheduled air transportation \\
\hline 1.58 & 3351 & Electric lighting equipment manufacturing \\
\hline 1.58 & 5616 & Investigation and security services \\
\hline 1.57 & 481 & Air transportation \\
\hline 1.55 & 4235 & Metal and mineral (except petroleum) merchant wholesalers \\
\hline 1.53 & 31 & Manufacturing \\
\hline 1.53 & 3328 & Coating, engraving, heat treating, and allied activities \\
\hline 1.53 & 3343 & Audio and video equipment manufacturing \\
\hline 1.53 & 4881 & Support activities for air transportation \\
\hline 1.52 & 5321 & Automotive equipment rental and leasing \\
\hline 1.51 & 6113 & Colleges, universities, and professional schools \\
\hline 1.51 & 3255 & Paint, coating, and adhesive manufacturing \\
\hline 1.51 & 4239 & Miscellaneous durable goods merchant wholesalers \\
\hline 1.50 & 3371 & Household and institutional furniture $\mathrm{mfg}$. \\
\hline 1.50 & 3313 & Alumina and aluminum production and processing \\
\hline 1.49 & 5418 & Advertising, public relations, and related services \\
\hline 1.48 & 4922 & Local messengers and local delivery \\
\hline 1.47 & 3326 & Spring and wire product manufacturing \\
\hline
\end{tabular}




\begin{tabular}{|c|c|c|}
\hline 1.46 & 337 & Furniture and related product manufacturing \\
\hline 1.44 & 51 & Information \\
\hline 1.43 & 4812 & Nonscheduled air transportation \\
\hline 1.43 & 7112 & Spectator sports \\
\hline 1.42 & 7113 & Promoters of performing arts, sports, and similar events \\
\hline 1.41 & 3372 & Office furniture (including fixtures) manufacturing \\
\hline 1.41 & 3363 & Motor vehicle parts manufacturing \\
\hline 1.40 & 4246 & Chemical and allied products merchant wholesalers \\
\hline 1.40 & 4859 & Other transit and ground passenger transportation \\
\hline 1.39 & 323 & Printing and related support activities \\
\hline 1.39 & 3231 & Printing and related support activities \\
\hline 1.39 & 4852 & Interurban and rural bus transportation \\
\hline 1.39 & 3222 & Converted paper product manufacturing \\
\hline 1.39 & 424 & Merchant wholesalers, nondurable goods \\
\hline 1.37 & 48 & Transportation and warehousing \\
\hline 1.36 & 3379 & Other furniture related product manufacturing \\
\hline 1.35 & 4244 & Grocery and related product merchant wholesalers \\
\hline 1.34 & 3262 & Rubber product manufacturing \\
\hline 1.34 & 322 & Paper manufacturing \\
\hline 1.34 & 4241 & Paper and paper product merchant wholesalers \\
\hline 1.32 & 5414 & Specialized design services \\
\hline 1.30 & 61 & Educational services \\
\hline 1.30 & 611 & Educational services \\
\hline 1.30 & 3252 & Resin, rubber, and artificial fibers $\mathrm{mfg}$. \\
\hline 1.29 & 812 & Personal and laundry services \\
\hline 1.28 & 4851 & Urban transit systems \\
\hline 1.27 & 7111 & Performing arts companies \\
\hline 1.27 & 4231 & Motor vehicle and parts merchant wholesalers \\
\hline 1.27 & 4853 & Taxi and limousine service \\
\hline 1.27 & 485 & Transit and ground passenger transportation \\
\hline 1.26 & 3329 & Other fabricated metal product manufacturing \\
\hline 1.25 & 4854 & School and employee bus transportation \\
\hline 1.25 & 335 & $\begin{array}{l}\text { Electrical equipment, appliance, and component } \\
\text { manufacturing }\end{array}$ \\
\hline 1.25 & 3118 & Bakeries and tortilla manufacturing \\
\hline
\end{tabular}

2007 NAICS

USEMP

12.16

12.04

11.73

10.56

10.18

8.83 code

3152

5121

512

7114

315

7115

\section{Description}

Cut and sew apparel manufacturing

Motion picture and video industries

Motion picture and sound recording industries

Agents and managers for public figures

Apparel manufacturing

Independent artists, writers, and performers 


\begin{tabular}{|c|c|c|}
\hline 7.47 & 5122 & Sound recording industries \\
\hline 6.31 & 4883 & Support activities for water transportation \\
\hline 5.18 & 4243 & Apparel, piece goods, and notions merchant wholesalers \\
\hline 4.64 & 3133 & Textile and fabric finishing and fabric coating mills \\
\hline 3.86 & 5152 & Cable and other subscription programming \\
\hline 3.74 & 3169 & Other leather and allied product manufacturing \\
\hline 3.68 & 3159 & Apparel accessories and other apparel manufacturing \\
\hline 3.41 & 3342 & Communications equipment manufacturing \\
\hline 2.93 & 5412 & $\begin{array}{l}\text { Accounting, tax preparation, bookkeeping, and payroll } \\
\text { services }\end{array}$ \\
\hline 2.75 & 3111 & Animal food manufacturing \\
\hline 2.73 & 8129 & Other personal services \\
\hline 2.70 & 3343 & Audio and video equipment manufacturing \\
\hline 2.69 & 4922 & Local messengers and local delivery \\
\hline 2.64 & 711 & Performing arts, spectator sports, and related industries \\
\hline 2.59 & 4851 & Urban transit systems \\
\hline 2.57 & 316 & Leather and allied product manufacturing \\
\hline 2.55 & 488 & Support activities for transportation \\
\hline 2.54 & 3364 & Aerospace product and parts manufacturing \\
\hline 2.53 & 4232 & Furniture and home furnishing merchant wholesalers \\
\hline 2.49 & 4885 & Freight transportation arrangement \\
\hline 2.44 & 3351 & Electric lighting equipment manufacturing \\
\hline 2.37 & 3149 & Other textile product mills \\
\hline 2.33 & 5418 & Advertising, public relations, and related services \\
\hline 2.30 & 5616 & Investigation and security services \\
\hline 2.23 & 4239 & Miscellaneous durable goods merchant wholesalers \\
\hline 2.17 & 3256 & $\begin{array}{l}\text { Soap, cleaning compound, and toilet preparation } \\
\text { manufacturing }\end{array}$ \\
\hline 2.14 & 515 & Broadcasting (except Internet) \\
\hline 2.05 & 51 & Information \\
\hline 1.98 & 5414 & Specialized design services \\
\hline 1.95 & 314 & Textile product mills \\
\hline 1.95 & 533 & Lessors of nonfinancial intangible assets \\
\hline 1.95 & 5331 & Lessors of nonfinancial intangible assets \\
\hline 1.89 & 4831 & Deep sea, coastal, and great lakes water transportation \\
\hline 1.88 & 31 & Manufacturing \\
\hline 1.87 & 324 & Petroleum and coal products manufacturing \\
\hline 1.87 & 3241 & Petroleum and coal products manufacturing \\
\hline 1.86 & 519 & Other information services \\
\hline 1.86 & 5191 & Other information services \\
\hline 1.85 & 5151 & Radio and television broadcasting \\
\hline 1.80 & 7132 & Gambling industries \\
\hline 1.78 & 3119 & Other food manufacturing \\
\hline 1.78 & 313 & Textile mills \\
\hline 1.77 & 3328 & Coating, engraving, heat treating, and allied activities \\
\hline
\end{tabular}




\begin{tabular}{|c|c|c|}
\hline 1.77 & 3346 & Manufacturing and reproducing magnetic and optical media \\
\hline 1.74 & 4244 & Grocery and related product merchant wholesalers \\
\hline 1.73 & 3162 & Footwear manufacturing \\
\hline 1.72 & 3325 & Hardware manufacturing \\
\hline 1.70 & 3379 & Other furniture related product manufacturing \\
\hline 1.69 & 424 & Merchant wholesalers, nondurable goods \\
\hline 1.66 & 7111 & Performing arts companies \\
\hline 1.59 & 5321 & Automotive equipment rental and leasing \\
\hline 1.59 & 4884 & Support activities for road transportation \\
\hline 1.55 & 3345 & Electronic instrument manufacturing \\
\hline 1.55 & 5324 & Machinery and equipment rental and leasing \\
\hline 1.53 & 6116 & Other schools and instruction \\
\hline 1.53 & 334 & Computer and electronic product manufacturing \\
\hline 1.53 & 4882 & Support activities for rail transportation \\
\hline 1.53 & 5179 & Other telecommunications \\
\hline 1.52 & 3118 & Bakeries and tortilla manufacturing \\
\hline 1.51 & 2212 & Natural gas distribution \\
\hline 1.50 & 3141 & Textile furnishings mills \\
\hline 1.49 & 4881 & Support activities for air transportation \\
\hline 1.49 & 7112 & Spectator sports \\
\hline 1.47 & 7131 & Amusement parks and arcades \\
\hline 1.47 & 7113 & Promoters of performing arts, sports, and similar events \\
\hline 1.41 & 42 & Wholesale trade \\
\hline 1.41 & 4231 & Motor vehicle and parts merchant wholesalers \\
\hline 1.41 & 54 & Professional, scientific, and technical services \\
\hline 1.41 & 541 & Professional, scientific, and technical services \\
\hline 1.40 & 6117 & Educational support services \\
\hline 1.39 & 4235 & Metal and mineral (except petroleum) merchant wholesalers \\
\hline 1.39 & 4241 & Paper and paper product merchant wholesalers \\
\hline 1.38 & 483 & Water transportation \\
\hline 1.37 & 4811 & Scheduled air transportation \\
\hline 1.35 & 3327 & Machine shops and threaded product mfg. \\
\hline 1.35 & 481 & Air transportation \\
\hline 1.35 & 5313 & Activities related to real estate \\
\hline 1.33 & 4859 & Other transit and ground passenger transportation \\
\hline 1.31 & 812 & Personal and laundry services \\
\hline 1.30 & 3371 & Household and institutional furniture $\mathrm{mfg}$. \\
\hline 1.28 & 71 & Arts, entertainment, and recreation \\
\hline 1.28 & 337 & Furniture and related product manufacturing \\
\hline 1.28 & 5416 & Management, scientific, and technical consulting services \\
\hline 1.28 & 532 & Rental and leasing services \\
\hline 1.27 & 5411 & Legal services \\
\hline 1.27 & 4246 & Chemical and allied products merchant wholesalers \\
\hline 1.26 & 8132 & Grantmaking and giving services \\
\hline 1.26 & 423 & Merchant wholesalers, durable goods \\
\hline
\end{tabular}




$\begin{array}{ccl}1.26 & 3399 & \text { Other miscellaneous manufacturing } \\ 1.25 & 53 & \text { Real estate and rental and leasing } \\ 1.25 & 5615 & \text { Travel arrangement and reservation services } \\ 1.25 & 492 & \text { Couriers and messengers }\end{array}$

2007 NAICS

\section{Description}

Independent artists, writers, and performers

Agents and managers for public figures

Cut and sew apparel manufacturing

Apparel manufacturing

Motion picture and video industries

Performing arts, spectator sports, and related industries

Motion picture and sound recording industries

Fabric mills

Apparel, piece goods, and notions merchant wholesalers

Sound recording industries

Footwear manufacturing

Textile mills

Textile and fabric finishing and fabric coating mills

Apparel knitting mills

Apparel accessories and other apparel manufacturing

Cable and other subscription programming

Leather and hide tanning and finishing

Arts, entertainment, and recreation

Other textile product mills

Performing arts companies

Fiber, yarn, and thread mills

Seafood product preparation and packaging

Textile product mills

Miscellaneous durable goods merchant wholesalers

Freight transportation arrangement

Monetary authorities- central bank

Tobacco manufacturing

Monetary authorities- central bank

Manufacturing

Foundries

Merchant wholesalers, nondurable goods

Leather and allied product manufacturing

Furniture and home furnishing merchant wholesalers

Steel product manufacturing from purchased steel

Scheduled air transportation

Information

Soap, cleaning compound, and toilet preparation manufacturing 


\begin{tabular}{|c|c|c|}
\hline 1.51 & 8129 & Other personal services \\
\hline 1.51 & 3364 & Aerospace product and parts manufacturing \\
\hline 1.50 & 4883 & Support activities for water transportation \\
\hline 1.47 & 331 & Primary metal manufacturing \\
\hline 1.47 & 4831 & Deep sea, coastal, and great lakes water transportation \\
\hline 1.45 & 3328 & Coating, engraving, heat treating, and allied activities \\
\hline 1.45 & 3321 & Forging and stamping \\
\hline 1.44 & 3351 & Electric lighting equipment manufacturing \\
\hline 1.42 & 5174 & Satellite telecommunications \\
\hline 1.42 & 3379 & Other furniture related product manufacturing \\
\hline 1.42 & 4249 & Miscellaneous nondurable goods merchant wholesalers \\
\hline 1.42 & 4242 & Drugs and druggists' sundries merchant wholesalers \\
\hline 1.42 & 3313 & Alumina and aluminum production and processing \\
\hline 1.41 & 4889 & Other support activities for transportation \\
\hline 1.41 & 7113 & Promoters of performing arts, sports, and similar events \\
\hline 1.39 & 4231 & Motor vehicle and parts merchant wholesalers \\
\hline 1.39 & 488 & Support activities for transportation \\
\hline 1.38 & 3141 & Textile furnishings mills \\
\hline 1.37 & 42 & Wholesale trade \\
\hline 1.37 & 3335 & Metalworking machinery manufacturing \\
\hline 1.36 & 5414 & Specialized design services \\
\hline 1.35 & 4244 & Grocery and related product merchant wholesalers \\
\hline 1.35 & 3336 & $\begin{array}{l}\text { Engine, turbine, and power transmission equipment } \\
\text { manufacturing }\end{array}$ \\
\hline 1.35 & 3116 & Animal slaughtering and processing \\
\hline 1.34 & 3325 & Hardware manufacturing \\
\hline 1.32 & 4241 & Paper and paper product merchant wholesalers \\
\hline 1.30 & 2212 & Natural gas distribution \\
\hline 1.30 & 483 & Water transportation \\
\hline 1.29 & 3255 & Paint, coating, and adhesive manufacturing \\
\hline 1.28 & 481 & Air transportation \\
\hline 1.28 & 4235 & Metal and mineral (except petroleum) merchant wholesalers \\
\hline 1.27 & 3222 & Converted paper product manufacturing \\
\hline 1.27 & 5615 & Travel arrangement and reservation services \\
\hline 1.27 & 322 & Paper manufacturing \\
\hline 1.26 & 3262 & Rubber product manufacturing \\
\hline 1.26 & 423 & Merchant wholesalers, durable goods \\
\hline 1.26 & 4922 & Local messengers and local delivery \\
\hline 1.25 & 3399 & Other miscellaneous manufacturing \\
\hline 1.25 & 5418 & Advertising, public relations, and related services \\
\hline 1.25 & 3118 & Bakeries and tortilla manufacturing \\
\hline 1.25 & 3326 & Spring and wire product manufacturing \\
\hline 1.25 & 3372 & Office furniture (including fixtures) manufacturing \\
\hline 1.25 & 3274 & Lime and gypsum product manufacturing \\
\hline 1.25 & 4855 & Charter bus industry \\
\hline
\end{tabular}




\begin{tabular}{|c|c|c|}
\hline \multicolumn{3}{|c|}{2007 NAICS } \\
\hline USEST & code & Description \\
\hline 11.50 & 3152 & Cut and sew apparel manufacturing \\
\hline 11.27 & 7115 & Independent artists, writers, and performers \\
\hline 10.20 & 315 & Apparel manufacturing \\
\hline 7.57 & 7114 & Agents and managers for public figures \\
\hline 7.36 & 5121 & Motion picture and video industries \\
\hline 7.05 & 512 & Motion picture and sound recording industries \\
\hline 6.86 & 711 & Performing arts, spectator sports, and related industries \\
\hline 6.61 & 4243 & Apparel, piece goods, and notions merchant wholesalers \\
\hline 5.38 & 5122 & Sound recording industries \\
\hline 3.86 & 3133 & Textile and fabric finishing and fabric coating mills \\
\hline 3.74 & 3162 & Footwear manufacturing \\
\hline 3.23 & 3151 & Apparel knitting mills \\
\hline 3.22 & 3149 & Other textile product mills \\
\hline 3.09 & 5152 & Cable and other subscription programming \\
\hline 2.90 & 7111 & Performing arts companies \\
\hline 2.88 & 31 & Manufacturing \\
\hline 2.87 & 313 & Textile mills \\
\hline 2.81 & 3159 & Apparel accessories and other apparel manufacturing \\
\hline 2.80 & 71 & Arts, entertainment, and recreation \\
\hline 2.72 & 4239 & Miscellaneous durable goods merchant wholesalers \\
\hline 2.69 & 3346 & Manufacturing and reproducing magnetic and optical media \\
\hline 2.64 & 314 & Textile product mills \\
\hline 2.59 & 3351 & Electric lighting equipment manufacturing \\
\hline 2.49 & 3343 & Audio and video equipment manufacturing \\
\hline 2.45 & 4232 & Furniture and home furnishing merchant wholesalers \\
\hline 2.36 & 3132 & Fabric mills \\
\hline 2.34 & 3364 & Aerospace product and parts manufacturing \\
\hline 2.25 & 424 & Merchant wholesalers, nondurable goods \\
\hline 2.21 & 3161 & Leather and hide tanning and finishing \\
\hline 2.20 & 4885 & Freight transportation arrangement \\
\hline 2.18 & 525 & Funds, trusts, and other financial vehicles \\
\hline 2.18 & 5259 & Other investment pools and funds \\
\hline 2.18 & 4242 & $\begin{array}{l}\text { Drugs and druggists' sundries merchant wholesalers } \\
\text { Soap, cleaning compound, and toilet preparation }\end{array}$ \\
\hline 2.08 & 3256 & manufacturing \\
\hline 2.05 & 4249 & Miscellaneous nondurable goods merchant wholesalers \\
\hline 2.00 & 8129 & Other personal services \\
\hline 1.96 & 316 & Leather and allied product manufacturing \\
\hline 1.96 & 51 & Information \\
\hline 1.91 & 3379 & Other furniture related product manufacturing \\
\hline 1.91 & 4244 & Grocery and related product merchant wholesalers \\
\hline 1.84 & 3328 & Coating, engraving, heat treating, and allied activities \\
\hline 1.84 & 5174 & Satellite telecommunications \\
\hline
\end{tabular}




\begin{tabular}{|c|c|c|}
\hline 1.81 & 5414 & Specialized design services \\
\hline 1.74 & 4851 & Urban transit systems \\
\hline 1.73 & 3118 & Bakeries and tortilla manufacturing \\
\hline 1.69 & 3119 & Other food manufacturing \\
\hline 1.67 & 42 & Wholesale trade \\
\hline 1.67 & 4236 & Electrical and electronic goods merchant wholesalers \\
\hline 1.64 & 3325 & Hardware manufacturing \\
\hline 1.63 & 488 & Support activities for transportation \\
\hline 1.59 & 5615 & Travel arrangement and reservation services \\
\hline 1.57 & 4231 & Motor vehicle and parts merchant wholesalers \\
\hline 1.57 & 4541 & Electronic shopping and mail-order houses \\
\hline 1.53 & 3399 & Other miscellaneous manufacturing \\
\hline 1.53 & 7113 & Promoters of performing arts, sports, and similar events \\
\hline 1.53 & 4241 & Paper and paper product merchant wholesalers \\
\hline 1.52 & 4811 & Scheduled air transportation \\
\hline 1.50 & 3315 & Foundries \\
\hline 1.47 & 423 & Merchant wholesalers, durable goods \\
\hline 1.46 & 4889 & Other support activities for transportation \\
\hline 1.44 & 335 & $\begin{array}{l}\text { Electrical equipment, appliance, and component } \\
\text { manufacturing }\end{array}$ \\
\hline 1.44 & 3321 & Forging and stamping \\
\hline 1.42 & 4922 & Local messengers and local delivery \\
\hline 1.42 & 5418 & Advertising, public relations, and related services \\
\hline 1.41 & 3131 & Fiber, yarn, and thread mills \\
\hline 1.41 & 7112 & Spectator sports \\
\hline 1.41 & 5611 & Office administrative services \\
\hline 1.40 & 3274 & Lime and gypsum product manufacturing \\
\hline 1.40 & 3141 & Textile furnishings mills \\
\hline 1.40 & 6211 & Offices of physicians \\
\hline 1.40 & 3344 & $\begin{array}{l}\text { Semiconductor and other electronic component } \\
\text { manufacturing }\end{array}$ \\
\hline 1.39 & 4855 & Charter bus industry \\
\hline 1.38 & 3322 & Cutlery and handtool manufacturing \\
\hline 1.38 & 5223 & Activities related to credit intermediation \\
\hline 1.38 & 519 & Other information services \\
\hline 1.38 & 5191 & Other information services \\
\hline 1.36 & 5179 & Other telecommunications \\
\hline 1.36 & 3333 & Commercial and service industry machinery manufacturing \\
\hline 1.36 & 3169 & Other leather and allied product manufacturing \\
\hline 1.35 & 339 & Miscellaneous manufacturing \\
\hline 1.35 & 3272 & Glass and glass product manufacturing \\
\hline 1.35 & 3255 & Paint, coating, and adhesive manufacturing \\
\hline 1.35 & 334 & Computer and electronic product manufacturing \\
\hline 1.34 & 323 & Printing and related support activities \\
\hline 1.34 & 3231 & Printing and related support activities \\
\hline
\end{tabular}




$\begin{array}{lcl}1.33 & 3369 & \text { Other transportation equipment manufacturing } \\ 1.33 & 3359 & \text { Other electrical equipment and component manufacturing } \\ 1.33 & 5313 & \text { Activities related to real estate } \\ 1.33 & 337 & \text { Furniture and related product manufacturing } \\ 1.32 & 4234 & \text { Commercial equip. merchant wholesalers } \\ 1.32 & 3372 & \text { Office furniture (including fixtures) manufacturing } \\ 1.30 & 311 & \text { Food manufacturing } \\ 1.30 & 5324 & \text { Machinery and equipment rental and leasing } \\ 1.29 & 6212 & \text { Offices of dentists } \\ 1.29 & 5616 & \text { Investigation and security services } \\ 1.29 & 3371 & \text { Household and institutional furniture mfg. } \\ 1.28 & 481 & \text { Air transportation } \\ 1.28 & 3313 & \text { Alumina and aluminum production and processing } \\ 1.28 & 4235 & \text { Metal and mineral (except petroleum) merchant wholesalers } \\ 1.26 & 6111 & \text { Elementary and secondary schools } \\ 1.25 & 3341 & \text { Computer and peripheral equipment manufacturing } \\ 1.25 & 331 & \text { Primary metal manufacturing }\end{array}$

\section{Orange County}

$\begin{array}{cc}\text { STEMP } & \begin{array}{c}\text { 2007 NAICS } \\ \text { Code }\end{array} \\ 7.60 & 3122 \\ 4.79 & 7131 \\ 3.75 & 2372 \\ 3.02 & 4862 \\ 2.91 & 3391 \\ 2.78 & 5619 \\ 2.35 & 5222 \\ 2.31 & 339 \\ 2.30 & 525 \\ 2.30 & 5259 \\ 2.20 & 3342 \\ 2.15 & 425 \\ 2.15 & 4251 \\ 2.14 & 3353 \\ 2.09 & 3328 \\ 2.01 & 3322 \\ 2.00 & 4242 \\ 1.92 & 3343 \\ 1.91 & 3333 \\ 1.90 & 5313 \\ 1.89 & 5615 \\ 1.86 & 3334\end{array}$

\section{Description}

Tobacco manufacturing

Amusement parks and arcades

Land subdivision

Pipeline transportation of natural gas

Medical equipment and supplies manufacturing

Other support services

Nondepository credit intermediation

Miscellaneous manufacturing

Funds, trusts, and other financial vehicles

Other investment pools and funds

Communications equipment manufacturing

Wholesale electronic markets and agents and brokers

Wholesale electronic markets and agents and brokers

Electrical equipment manufacturing

Coating, engraving, heat treating, and allied activities

Cutlery and handtool manufacturing

Drugs and druggists' sundries merchant wholesalers

Audio and video equipment manufacturing

Commercial and service industry machinery manufacturing

Activities related to real estate

Travel arrangement and reservation services

HVAC and commercial refrigeration equipment 


\begin{tabular}{|c|c|c|}
\hline 1.85 & 5172 & Wireless telecommunications carriers (except satellite) \\
\hline 1.84 & 6215 & Medical and diagnostic laboratories \\
\hline 1.83 & 3327 & Machine shops and threaded product mfg. \\
\hline 1.83 & 3141 & Textile furnishings mills \\
\hline 1.79 & 4832 & Inland water transportation \\
\hline 1.76 & 3221 & Pulp, paper, and paperboard mills \\
\hline 1.76 & 335 & Electrical equipment, appliance, and component manufacturing \\
\hline 1.73 & 3162 & Footwear manufacturing \\
\hline 1.73 & 3321 & Forging and stamping \\
\hline 1.69 & 3344 & Semiconductor and other electronic component manufacturing \\
\hline 1.69 & 4234 & Commercial equip. merchant wholesalers \\
\hline 1.67 & 533 & Lessors of nonfinancial intangible assets \\
\hline 1.67 & 5331 & Lessors of nonfinancial intangible assets \\
\hline 1.65 & 3339 & Other general purpose machinery manufacturing \\
\hline 1.63 & 3341 & Computer and peripheral equipment manufacturing \\
\hline 1.63 & 3359 & Other electrical equipment and component manufacturing \\
\hline 1.62 & 3351 & Electric lighting equipment manufacturing \\
\hline 1.62 & 4872 & Scenic and sightseeing transportation, water \\
\hline 1.61 & 3335 & Metalworking machinery manufacturing \\
\hline 1.58 & 4237 & Hardware and plumbing merchant wholesalers \\
\hline 1.56 & 3313 & Alumina and aluminum production and processing \\
\hline 1.56 & 5241 & Insurance carriers \\
\hline 1.55 & 1142 & Hunting and trapping \\
\hline 1.53 & 3133 & Textile and fabric finishing and fabric coating mills \\
\hline 1.53 & 3399 & Other miscellaneous manufacturing \\
\hline 1.52 & 332 & Fabricated metal product manufacturing \\
\hline 1.51 & 3329 & Other fabricated metal product manufacturing \\
\hline 1.51 & 323 & Printing and related support activities \\
\hline 1.51 & 3231 & Printing and related support activities \\
\hline 1.50 & 531 & Real estate \\
\hline 1.49 & 4231 & Motor vehicle and parts merchant wholesalers \\
\hline 1.47 & 334 & Computer and electronic product manufacturing \\
\hline 1.45 & 3262 & Rubber product manufacturing \\
\hline 1.44 & 4246 & Chemical and allied products merchant wholesalers \\
\hline 1.44 & 3331 & Agriculture, construction, and mining machinery manufacturing \\
\hline 1.44 & 3363 & Motor vehicle parts manufacturing \\
\hline 1.43 & 314 & Textile product mills \\
\hline 1.42 & 5223 & Activities related to credit intermediation \\
\hline 1.41 & 524 & Insurance carriers and related activities \\
\hline 1.41 & 5614 & Business support services \\
\hline 1.40 & 5416 & Management, scientific, and technical consulting services \\
\hline 1.39 & 2383 & Building finishing contractors \\
\hline 1.39 & 4243 & Apparel, piece goods, and notions merchant wholesalers \\
\hline 1.39 & 522 & Credit intermediation and related activities \\
\hline 1.38 & 5111 & Newspaper, periodical, book, and directory publishers \\
\hline
\end{tabular}




$\begin{array}{lcl}1.38 & 6219 & \text { Other ambulatory health care services } \\ 1.38 & 326 & \text { Plastics and rubber products manufacturing } \\ 1.37 & 3352 & \text { Household appliance manufacturing } \\ 1.37 & 2362 & \text { Nonresidential building construction } \\ 1.37 & 4241 & \text { Paper and paper product merchant wholesalers } \\ 1.37 & 3261 & \text { Plastics product manufacturing } \\ 1.37 & 237 & \text { Heavy and civil engineering construction } \\ 1.36 & 52 & \text { Finance and insurance } \\ 1.36 & 6213 & \text { Offices of other health practitioners } \\ 1.36 & 713 & \text { Amusement, gambling, and recreation industries } \\ 1.36 & 4238 & \text { Machinery, equipment, and supplies merchant wholesalers } \\ 1.35 & 333 & \text { Machinery manufacturing } \\ 1.35 & 3372 & \text { Office furniture (including fixtures) manufacturing } \\ 1.35 & 423 & \text { Merchant wholesalers, durable goods } \\ 1.31 & 5413 & \text { Architectural, engineering, and related services } \\ 1.31 & 53 & \text { Real estate and rental and leasing } \\ 1.30 & 5617 & \text { Services to buildings and dwellings } \\ 1.28 & 3255 & \text { Paint, coating, and adhesive manufacturing } \\ 1.27 & 5239 & \text { Other financial investment activities } \\ 1.26 & 313 & \text { Textile mills } \\ 1.26 & 42 & \text { Wholesale trade } \\ 1.26 & 55 & \text { Management of companies and enterprises } \\ 1.26 & 551 & \text { Management of companies and enterprises } \\ 1.26 & 5511 & \text { Management of companies and enterprises } \\ 1.25 & 3274 & \text { Lime and gypsum product manufacturing } \\ & & \end{array}$

2007 NAICS

$\begin{array}{rcl}\text { USEMP } & \text { code } & \text { Description } \\ 10.97 & 7131 & \text { Amusement parks and arcades } \\ 6.62 & 3342 & \text { Communications equipment manufacturing } \\ 6.03 & 2372 & \text { Land subdivision } \\ 4.71 & 525 & \text { Funds, trusts, and other financial vehicles } \\ 4.71 & 5259 & \text { Other investment pools and funds } \\ 4.57 & 3391 & \text { Medical equipment and supplies manufacturing } \\ 3.41 & 3343 & \text { Audio and video equipment manufacturing } \\ 3.22 & 3344 & \text { Semiconductor and other electronic component manufacturing } \\ 3.18 & 3152 & \text { Cut and sew apparel manufacturing } \\ 3.14 & 4243 & \text { Apparel, piece goods, and notions merchant wholesalers } \\ 3.06 & 339 & \text { Miscellaneous manufacturing } \\ 2.98 & 5619 & \text { Other support services } \\ 2.73 & 334 & \text { Computer and electronic product manufacturing } \\ 2.65 & 315 & \text { Apparel manufacturing } \\ 2.65 & 5313 & \text { Activities related to real estate } \\ 2.59 & 3133 & \text { Textile and fabric finishing and fabric coating mills }\end{array}$




\begin{tabular}{|c|c|c|}
\hline 2.53 & 4234 & Commercial equip. merchant wholesalers \\
\hline 2.52 & 4236 & Electrical and electronic goods merchant wholesalers \\
\hline 2.50 & 3351 & Electric lighting equipment manufacturing \\
\hline 2.48 & 3341 & Computer and peripheral equipment manufacturing \\
\hline 2.48 & 5222 & Nondepository credit intermediation \\
\hline 2.47 & 4872 & Scenic and sightseeing transportation, water \\
\hline 2.41 & 3328 & Coating, engraving, heat treating, and allied activities \\
\hline 2.39 & 425 & Wholesale electronic markets and agents and brokers \\
\hline 2.39 & 4251 & Wholesale electronic markets and agents and brokers \\
\hline 2.22 & 4242 & Drugs and druggists' sundries merchant wholesalers \\
\hline 2.08 & 3346 & Manufacturing and reproducing magnetic and optical media \\
\hline 2.05 & 5615 & Travel arrangement and reservation services \\
\hline 2.01 & 2383 & Building finishing contractors \\
\hline 2.01 & 3327 & Machine shops and threaded product mfg. \\
\hline 1.95 & 4237 & Hardware and plumbing merchant wholesalers \\
\hline 1.93 & 531 & Real estate \\
\hline 1.91 & 3333 & Commercial and service industry machinery manufacturing \\
\hline 1.90 & 533 & Lessors of nonfinancial intangible assets \\
\hline 1.90 & 5331 & Lessors of nonfinancial intangible assets \\
\hline 1.89 & 6215 & Medical and diagnostic laboratories \\
\hline 1.88 & 5418 & Advertising, public relations, and related services \\
\hline 1.83 & 3254 & Pharmaceutical and medicine manufacturing \\
\hline 1.77 & 4922 & Local messengers and local delivery \\
\hline 1.76 & 423 & Merchant wholesalers, durable goods \\
\hline 1.74 & 713 & Amusement, gambling, and recreation industries \\
\hline 1.68 & 5414 & Specialized design services \\
\hline 1.68 & 3399 & Other miscellaneous manufacturing \\
\hline 1.67 & 5223 & Activities related to credit intermediation \\
\hline 1.66 & 4231 & Motor vehicle and parts merchant wholesalers \\
\hline 1.63 & 7115 & Independent artists, writers, and performers \\
\hline 1.62 & 5416 & Management, scientific, and technical consulting services \\
\hline 1.60 & 6116 & Other schools and instruction \\
\hline 1.60 & 53 & Real estate and rental and leasing \\
\hline 1.59 & 42 & Wholesale trade \\
\hline 1.58 & 8112 & Electronic and precision equipment repair and maintenance \\
\hline 1.55 & 2381 & Foundation, structure, and building exterior contractors \\
\hline 1.55 & 4239 & Miscellaneous durable goods merchant wholesalers \\
\hline 1.51 & 5172 & Wireless telecommunications carriers (except satellite) \\
\hline 1.51 & 3369 & Other transportation equipment manufacturing \\
\hline 1.49 & 4232 & Furniture and home furnishing merchant wholesalers \\
\hline 1.49 & 71 & Arts, entertainment, and recreation \\
\hline 1.46 & 5179 & Other telecommunications \\
\hline 1.46 & 5413 & Architectural, engineering, and related services \\
\hline 1.46 & 3359 & Other electrical equipment and component manufacturing \\
\hline 1.45 & 3379 & Other furniture related product manufacturing \\
\hline
\end{tabular}




$\begin{array}{lcl}1.42 & 5312 & \text { Offices of real estate agents and brokers } \\ 1.42 & 4241 & \text { Paper and paper product merchant wholesalers } \\ 1.40 & 3169 & \text { Other leather and allied product manufacturing } \\ 1.39 & 8129 & \text { Other personal services } \\ 1.39 & 5311 & \text { Lessors of real estate } \\ 1.37 & 5617 & \text { Services to buildings and dwellings } \\ 1.35 & 238 & \text { Specialty trade contractors } \\ 1.35 & 335 & \text { Electrical equipment, appliance, and component manufacturing } \\ 1.33 & 5239 & \text { Other financial investment activities } \\ 1.32 & 2362 & \text { Nonresidential building construction } \\ 1.32 & 323 & \text { Printing and related support activities } \\ 1.32 & 3231 & \text { Printing and related support activities } \\ 1.31 & 4851 & \text { Urban transit systems } \\ 1.31 & 4246 & \text { Chemical and allied products merchant wholesalers } \\ 1.31 & 522 & \text { Credit intermediation and related activities } \\ 1.29 & 23 & \text { Construction } \\ 1.29 & 3141 & \text { Textile furnishings mills } \\ 1.29 & 332 & \text { Fabricated metal product manufacturing } \\ 1.28 & 4884 & \text { Support activities for road transportation } \\ 1.28 & 4481 & \text { Clothing stores } \\ 1.27 & 236 & \text { Construction of buildings } \\ 1.27 & 3322 & \text { Cutlery and handtool manufacturing } \\ 1.27 & 3353 & \text { Electrical equipment manufacturing } \\ 1.27 & 5112 & \text { Software publishers } \\ 1.27 & 314 & \text { Textile product mills } \\ 1.26 & 6213 & \text { Offices of other health practitioners } \\ 1.26 & 4541 & \text { Electronic shopping and mail-order houses } \\ 1.26 & 4521 & \text { Department stores } \\ 1.26 & 3345 & \text { Electronic instrument manufacturing } \\ 1.25 & 54 & \text { Professional, scientific, and technical services } \\ 1.25 & 541 & \text { Professional, scientific, and technical services } \\ 1.25 & 3149 & \text { Other textile product mills } \\ & & \\ 1.29 & & \end{array}$

2007 NAICS

\section{Description}

Tobacco manufacturing

Motor vehicle manufacturing

$2.05 \quad 3361$

Funds, trusts, and other financial vehicles

$2.02 \quad 525$

$2.02 \quad 5259$

$1.95 \quad 3364$

$1.84 \quad 3322$

$1.80 \quad 3363$

$1.78 \quad 3333$

$1.77 \quad 3344$

Other investment pools and funds

Aerospace product and parts manufacturing

Cutlery and handtool manufacturing

Motor vehicle parts manufacturing

Commercial and service industry machinery manufacturing

Semiconductor and other electronic component manufacturing 


\begin{tabular}{|c|c|c|}
\hline 1.75 & 533 & Lessors of nonfinancial intangible assets \\
\hline 1.75 & 5331 & Lessors of nonfinancial intangible assets \\
\hline 1.74 & 3314 & Nonferrous metal (except aluminum) production and processing \\
\hline 1.70 & 425 & Wholesale electronic markets and agents and brokers \\
\hline 1.70 & 4251 & Wholesale electronic markets and agents and brokers \\
\hline 1.70 & 3369 & Other transportation equipment manufacturing \\
\hline 1.69 & 3252 & Resin, rubber, and artificial fibers mfg. \\
\hline 1.67 & 3341 & Computer and peripheral equipment manufacturing \\
\hline 1.66 & 3141 & Textile furnishings mills \\
\hline 1.65 & 336 & Transportation equipment manufacturing \\
\hline 1.65 & 3335 & Metalworking machinery manufacturing \\
\hline 1.63 & 3254 & Pharmaceutical and medicine manufacturing \\
\hline 1.63 & 3328 & Coating, engraving, heat treating, and allied activities \\
\hline 1.62 & 4236 & Electrical and electronic goods merchant wholesalers \\
\hline 1.60 & 4234 & Commercial equip. merchant wholesalers \\
\hline 1.58 & 5222 & Nondepository credit intermediation \\
\hline 1.57 & 3359 & Other electrical equipment and component manufacturing \\
\hline 1.56 & 3321 & Forging and stamping \\
\hline 1.56 & 4246 & Chemical and allied products merchant wholesalers \\
\hline 1.54 & 4242 & Drugs and druggists' sundries merchant wholesalers \\
\hline 1.53 & 4241 & Paper and paper product merchant wholesalers \\
\hline 1.52 & 3351 & Electric lighting equipment manufacturing \\
\hline 1.51 & 334 & Computer and electronic product manufacturing \\
\hline 1.48 & 335 & Electrical equipment, appliance, and component manufacturing \\
\hline 1.48 & 3327 & Machine shops and threaded product mfg. \\
\hline 1.46 & 3391 & Medical equipment and supplies manufacturing \\
\hline 1.44 & 3261 & Plastics product manufacturing \\
\hline 1.43 & 3313 & Alumina and aluminum production and processing \\
\hline 1.42 & 2372 & Land subdivision \\
\hline 1.41 & 6215 & Medical and diagnostic laboratories \\
\hline 1.40 & 6223 & Specialty (except psychiatric and substance abuse) hospitals \\
\hline 1.40 & 333 & Machinery manufacturing \\
\hline 1.40 & 5223 & Activities related to credit intermediation \\
\hline 1.40 & 323 & Printing and related support activities \\
\hline 1.40 & 3231 & Printing and related support activities \\
\hline 1.40 & 3353 & Electrical equipment manufacturing \\
\hline 1.39 & 4872 & Scenic and sightseeing transportation, water \\
\hline 1.38 & 55 & Management of companies and enterprises \\
\hline 1.38 & 551 & Management of companies and enterprises \\
\hline 1.38 & 5511 & Management of companies and enterprises \\
\hline 1.38 & 3255 & Paint, coating, and adhesive manufacturing \\
\hline 1.38 & 5416 & Management, scientific, and technical consulting services \\
\hline 1.38 & 326 & Plastics and rubber products manufacturing \\
\hline 1.37 & 332 & Fabricated metal product manufacturing \\
\hline 1.36 & 339 & Miscellaneous manufacturing \\
\hline
\end{tabular}




$\begin{array}{lcl}1.36 & 3339 & \text { Other general purpose machinery manufacturing } \\ 1.36 & 7131 & \text { Amusement parks and arcades } \\ 1.35 & 3326 & \text { Spring and wire product manufacturing } \\ 1.34 & 3162 & \text { Footwear manufacturing } \\ 1.34 & 4238 & \text { Machinery, equipment, and supplies merchant wholesalers } \\ 1.33 & 314 & \text { Textile product mills } \\ 1.33 & 3345 & \text { Electronic instrument manufacturing } \\ 1.33 & 5611 & \text { Office administrative services } \\ 1.33 & 5241 & \text { Insurance carriers } \\ 1.33 & 3222 & \text { Converted paper product manufacturing } \\ 1.32 & 5619 & \text { Other support services } \\ 1.32 & 5418 & \text { Advertising, public relations, and related services } \\ 1.32 & 423 & \text { Merchant wholesalers, durable goods } \\ 1.31 & 3274 & \text { Lime and gypsum product manufacturing } \\ 1.31 & 4235 & \text { Metal and mineral (except petroleum) merchant wholesalers } \\ 1.31 & 4541 & \text { Electronic shopping and mail-order houses } \\ 1.31 & 5313 & \text { Activities related to real estate } \\ 1.30 & 8112 & \text { Electronic and precision equipment repair and maintenance } \\ 1.30 & 3399 & \text { Other miscellaneous manufacturing } \\ 1.29 & 322 & \text { Paper manufacturing } \\ 1.29 & 5413 & \text { Architectural, engineering, and related services } \\ 1.29 & 5415 & \text { Computer systems design and related services } \\ 1.29 & 524 & \text { Insurance carriers and related activities } \\ 1.29 & 3332 & \text { Industrial machinery manufacturing } \\ 1.28 & 2362 & \text { Nonresidential building construction } \\ 1.28 & 5242 & \text { Agencies, brokerages, and other insurance related activities } \\ 1.27 & 4832 & \text { Inland water transportation } \\ 1.26 & 5414 & \text { Specialized design services } \\ 1.26 & 3372 & \text { Office furniture (including fixtures) manufacturing } \\ 1.25 & 5613 & \text { Employment services } \\ 1.25 & 52 & \text { Finance and insurance } \\ & & \\ 1.32 & 36 & \end{array}$

\section{NAICS}

$\begin{array}{rc}\text { USEST } & \text { code } \\ 4.19 & 3344 \\ 4.01 & 525 \\ 4.01 & 5259 \\ 3.91 & 3341 \\ 3.41 & 3369 \\ 3.05 & 334 \\ 3.02 & 3364 \\ 2.98 & 3152 \\ 2.72 & 3351 \\ 2.68 & 3346\end{array}$

\section{Description}

Semiconductor and other electronic component manufacturing Funds, trusts, and other financial vehicles

Other investment pools and funds

Computer and peripheral equipment manufacturing

Other transportation equipment manufacturing

Computer and electronic product manufacturing

Aerospace product and parts manufacturing

Cut and sew apparel manufacturing

Electric lighting equipment manufacturing

Manufacturing and reproducing magnetic and optical media 


\begin{tabular}{|c|c|c|}
\hline 2.63 & 315 & Apparel manufacturing \\
\hline 2.55 & 3333 & Commercial and service industry machinery manufacturing \\
\hline 2.52 & 4236 & Electrical and electronic goods merchant wholesalers \\
\hline 2.40 & 3342 & Communications equipment manufacturing \\
\hline 2.35 & 4242 & Drugs and druggists' sundries merchant wholesalers \\
\hline 2.35 & 3254 & Pharmaceutical and medicine manufacturing \\
\hline 2.25 & 3361 & Motor vehicle manufacturing \\
\hline 2.19 & 3345 & Electronic instrument manufacturing \\
\hline 2.12 & 3322 & Cutlery and handtool manufacturing \\
\hline 2.09 & 3343 & Audio and video equipment manufacturing \\
\hline 2.08 & 3359 & Other electrical equipment and component manufacturing \\
\hline 2.07 & 3328 & Coating, engraving, heat treating, and allied activities \\
\hline 2.05 & 4234 & Commercial equip. merchant wholesalers \\
\hline 2.02 & 3162 & Footwear manufacturing \\
\hline 1.99 & 3149 & Other textile product mills \\
\hline 1.93 & 5223 & Activities related to credit intermediation \\
\hline 1.89 & 314 & Textile product mills \\
\hline 1.87 & 3391 & Medical equipment and supplies manufacturing \\
\hline 1.87 & 4243 & Apparel, piece goods, and notions merchant wholesalers \\
\hline 1.82 & 4541 & Electronic shopping and mail-order houses \\
\hline 1.81 & 4232 & Furniture and home furnishing merchant wholesalers \\
\hline 1.81 & 335 & Electrical equipment, appliance, and component manufacturing \\
\hline 1.80 & 425 & Wholesale electronic markets and agents and brokers \\
\hline 1.80 & 4251 & Wholesale electronic markets and agents and brokers \\
\hline 1.80 & 5416 & Management, scientific, and technical consulting services \\
\hline 1.77 & 4241 & Paper and paper product merchant wholesalers \\
\hline 1.77 & 3363 & Motor vehicle parts manufacturing \\
\hline 1.75 & 5112 & Software publishers \\
\hline 1.74 & 5313 & Activities related to real estate \\
\hline 1.72 & 336 & Transportation equipment manufacturing \\
\hline 1.70 & 339 & Miscellaneous manufacturing \\
\hline 1.69 & 533 & Lessors of nonfinancial intangible assets \\
\hline 1.69 & 5331 & Lessors of nonfinancial intangible assets \\
\hline 1.69 & 3141 & Textile furnishings mills \\
\hline 1.68 & 5611 & Office administrative services \\
\hline 1.67 & 3256 & Soap, cleaning compound, and toilet preparation manufacturing \\
\hline 1.67 & 5414 & Specialized design services \\
\hline 1.62 & 3327 & Machine shops and threaded product mfg. \\
\hline 1.59 & 4239 & Miscellaneous durable goods merchant wholesalers \\
\hline 1.59 & 5179 & Other telecommunications \\
\hline 1.59 & 3399 & Other miscellaneous manufacturing \\
\hline 1.56 & 5415 & Computer systems design and related services \\
\hline 1.54 & 3321 & Forging and stamping \\
\hline 1.54 & 423 & Merchant wholesalers, durable goods \\
\hline 1.53 & 323 & Printing and related support activities \\
\hline
\end{tabular}




\begin{tabular}{|c|c|c|}
\hline 1.53 & 3231 & Printing and related support activities \\
\hline 1.52 & 5417 & Scientific research and development services \\
\hline 1.51 & 42 & Wholesale trade \\
\hline 1.51 & 6212 & Offices of dentists \\
\hline 1.50 & 5418 & Advertising, public relations, and related services \\
\hline 1.49 & 3325 & Hardware manufacturing \\
\hline 1.48 & 5413 & Architectural, engineering, and related services \\
\hline 1.48 & 6215 & Medical and diagnostic laboratories \\
\hline 1.47 & 5239 & Other financial investment activities \\
\hline 1.47 & 3274 & Lime and gypsum product manufacturing \\
\hline 1.47 & 4246 & Chemical and allied products merchant wholesalers \\
\hline 1.46 & 3314 & Nonferrous metal (except aluminum) production and processing \\
\hline 1.45 & 3133 & Textile and fabric finishing and fabric coating mills \\
\hline 1.44 & 3255 & Paint, coating, and adhesive manufacturing \\
\hline 1.42 & 518 & Data processing, hosting and related services \\
\hline 1.42 & 5182 & Data processing, hosting, and related services \\
\hline 1.42 & 332 & Fabricated metal product manufacturing \\
\hline 1.42 & 4249 & Miscellaneous nondurable goods merchant wholesalers \\
\hline 1.41 & 54 & Professional, scientific, and technical services \\
\hline 1.41 & 541 & Professional, scientific, and technical services \\
\hline 1.40 & 2372 & Land subdivision \\
\hline 1.39 & 6211 & Offices of physicians \\
\hline 1.38 & 3261 & Plastics product manufacturing \\
\hline 1.35 & 8112 & Electronic and precision equipment repair and maintenance \\
\hline 1.35 & 5614 & Business support services \\
\hline 1.34 & 5222 & Nondepository credit intermediation \\
\hline 1.34 & 424 & Merchant wholesalers, nondurable goods \\
\hline 1.33 & 3252 & Resin, rubber, and artificial fibers $\mathrm{mfg}$. \\
\hline 1.33 & 3372 & Office furniture (including fixtures) manufacturing \\
\hline 1.33 & 3272 & Glass and glass product manufacturing \\
\hline 1.32 & 5174 & Satellite telecommunications \\
\hline 1.31 & 326 & Plastics and rubber products manufacturing \\
\hline 1.30 & 4235 & Metal and mineral (except petroleum) merchant wholesalers \\
\hline 1.29 & 5619 & Other support services \\
\hline 1.29 & 7112 & Spectator sports \\
\hline 1.29 & 523 & Securities, commodity contracts, investments \\
\hline 1.29 & 3313 & Alumina and aluminum production and processing \\
\hline 1.28 & 4237 & Hardware and plumbing merchant wholesalers \\
\hline 1.28 & 621 & Ambulatory health care services \\
\hline 1.28 & 5613 & Employment services \\
\hline 1.28 & 31 & Manufacturing \\
\hline 1.28 & 531 & Real estate \\
\hline 1.27 & 4231 & Motor vehicle and parts merchant wholesalers \\
\hline 1.26 & 5616 & Investigation and security services \\
\hline 1.25 & 5615 & Travel arrangement and reservation services \\
\hline
\end{tabular}




\section{Riverside County}

\begin{tabular}{|c|c|c|}
\hline \multirow{2}{*}{\multicolumn{2}{|c|}{$\begin{array}{lc}2007 \text { NAICS } \\
\text { STEMP } & \text { code }\end{array}$}} & \multirow[b]{2}{*}{ Description } \\
\hline & & \\
\hline 10.28 & 3362 & Motor vehicle body and trailer manufacturing \\
\hline 8.64 & 2121 & Coal mining \\
\hline 4.18 & 4882 & Support activities for rail transportation \\
\hline 3.92 & 3271 & Clay product and refractory manufacturing \\
\hline 3.78 & 3379 & Other furniture related product manufacturing \\
\hline 3.39 & 3279 & Other nonmetallic mineral product manufacturing \\
\hline 3.34 & 3324 & Boiler, tank, and shipping container manufacturing \\
\hline 3.19 & 3219 & Other wood product manufacturing \\
\hline 3.19 & 3252 & Resin, rubber, and artificial fibers $\mathrm{mfg}$. \\
\hline 3.05 & 493 & Warehousing and storage \\
\hline 3.05 & 4931 & Warehousing and storage \\
\hline 2.94 & 7212 & RV (recreational vehicle) parks and recreational camps \\
\hline 2.87 & 7132 & Gambling industries \\
\hline 2.80 & 3313 & Alumina and aluminum production and processing \\
\hline 2.79 & 5622 & Waste treatment and disposal \\
\hline 2.78 & 2371 & Utility system construction \\
\hline 2.72 & 2381 & Foundation, structure, and building exterior contractors \\
\hline 2.61 & 321 & Wood product manufacturing \\
\hline 2.50 & 237 & Heavy and civil engineering construction \\
\hline 2.50 & 1141 & Fishing \\
\hline 2.36 & 3329 & Other fabricated metal product manufacturing \\
\hline 2.32 & 2373 & Highway, street, and bridge construction \\
\hline 2.31 & 3261 & Plastics product manufacturing \\
\hline 2.27 & 4412 & Other motor vehicle dealers \\
\hline 2.21 & 5312 & Offices of real estate agents and brokers \\
\hline 2.19 & 4529 & Other general merchandise stores \\
\hline 2.15 & 6239 & Other residential care facilities \\
\hline 2.13 & 721 & Accommodation \\
\hline 2.12 & 7211 & Traveler accommodation \\
\hline 2.11 & 2383 & Building finishing contractors \\
\hline 2.10 & 326 & Plastics and rubber products manufacturing \\
\hline 2.10 & 2372 & Land subdivision \\
\hline 2.09 & 2379 & Other heavy and civil engineering construction \\
\hline 2.07 & 2389 & Other specialty trade contractors \\
\hline 2.06 & 3212 & Veneer, plywood, and engineered wood product manufacturing \\
\hline 2.05 & 238 & Specialty trade contractors \\
\hline 2.03 & 327 & Nonmetallic mineral product manufacturing \\
\hline 1.95 & 3391 & Medical equipment and supplies manufacturing \\
\hline 1.93 & 7139 & Other amusement and recreation industries \\
\hline 1.92 & 3273 & Cement and concrete product manufacturing \\
\hline 1.91 & 114 & Fishing, hunting and trapping \\
\hline
\end{tabular}




\begin{tabular}{|c|c|c|}
\hline 1.91 & 339 & Miscellaneous manufacturing \\
\hline 1.90 & 23 & Construction \\
\hline 1.86 & 3399 & Other miscellaneous manufacturing \\
\hline 1.86 & 4852 & Interurban and rural bus transportation \\
\hline 1.83 & 713 & Amusement, gambling, and recreation industries \\
\hline 1.82 & 3322 & Cutlery and handtool manufacturing \\
\hline 1.77 & 3363 & Motor vehicle parts manufacturing \\
\hline 1.77 & 6216 & Home health care services \\
\hline 1.75 & 2123 & Nonmetallic mineral mining and quarrying \\
\hline 1.75 & 3325 & Hardware manufacturing \\
\hline 1.72 & 3331 & Agriculture, construction, and mining machinery manufacturing \\
\hline 1.71 & 3169 & Other leather and allied product manufacturing \\
\hline 1.69 & 3323 & Architectural and structural metals manufacturing \\
\hline 1.69 & 452 & General merchandise stores \\
\hline 1.67 & 4421 & Furniture stores \\
\hline 1.65 & 212 & Mining (except oil and gas) \\
\hline 1.63 & 3326 & Spring and wire product manufacturing \\
\hline 1.57 & 447 & Gasoline stations \\
\hline 1.57 & 4471 & Gasoline stations \\
\hline 1.53 & 4245 & Farm product raw material merchant wholesalers \\
\hline 1.51 & 4413 & Automotive parts, accessories, and tire stores \\
\hline 1.51 & 441 & Motor vehicle and parts dealers \\
\hline 1.51 & 4521 & Department stores \\
\hline 1.50 & 2382 & Building equipment contractors \\
\hline 1.50 & 6232 & Residential mental health facilities \\
\hline 1.44 & 4233 & Lumber and other construction materials merchant wholesalers \\
\hline 1.43 & 3333 & Commercial and service industry machinery manufacturing \\
\hline 1.43 & 71 & Arts, entertainment, and recreation \\
\hline 1.42 & 4411 & Automobile dealers \\
\hline 1.42 & 4842 & Specialized freight trucking \\
\hline 1.41 & 4854 & School and employee bus transportation \\
\hline 1.41 & 32 & Manufacturing \\
\hline 1.41 & 5617 & Services to buildings and dwellings \\
\hline 1.39 & 4441 & Building material and supplies dealers \\
\hline 1.39 & 4482 & Shoe stores \\
\hline 1.38 & 444 & Building material and garden equipment and supplies dealers \\
\hline 1.38 & 4451 & Grocery stores \\
\hline 1.38 & 4884 & Support activities for road transportation \\
\hline 1.37 & 72 & Accommodation and food services \\
\hline 1.37 & 8139 & Professional and similar organizations \\
\hline 1.37 & 442 & Furniture and home furnishings stores \\
\hline 1.35 & 7222 & Limited-service eating places \\
\hline 1.35 & 3339 & Other general purpose machinery manufacturing \\
\hline 1.35 & 44 & Retail trade \\
\hline 1.34 & 445 & Food and beverage stores \\
\hline
\end{tabular}




$\begin{array}{lcl}1.33 & 337 & \text { Furniture and related product manufacturing } \\ 1.31 & 336 & \text { Transportation equipment manufacturing } \\ 1.30 & 3335 & \text { Metalworking machinery manufacturing } \\ 1.29 & 5323 & \text { General rental centers } \\ 1.29 & 5629 & \text { Remediation and other waste management services } \\ 1.29 & 5322 & \text { Consumer goods rental } \\ 1.29 & 8111 & \text { Automotive repair and maintenance } \\ 1.28 & 4541 & \text { Electronic shopping and mail-order houses } \\ 1.28 & 5324 & \text { Machinery and equipment rental and leasing } \\ 1.28 & 4442 & \text { Lawn and garden equipment and supplies stores } \\ 1.27 & 2361 & \text { Residential building construction } \\ 1.27 & 332 & \text { Fabricated metal product manufacturing } \\ 1.27 & 448 & \text { Clothing and clothing accessories stores } \\ 1.27 & 4481 & \text { Clothing stores } \\ 1.25 & 4532 & \text { Office supplies, stationery, and gift stores }\end{array}$

\section{NAICS}

$\begin{array}{rcl}\text { USEMP } & \text { code } & \text { Description } \\ 6.24 & 7132 & \text { Gambling industries } \\ 6.11 & 3362 & \text { Motor vehicle body and trailer manufacturing } \\ 4.70 & 3379 & \text { Other furniture related product manufacturing } \\ 3.49 & 7212 & \text { RV (recreational vehicle) parks and recreational camps } \\ 3.46 & 2381 & \text { Foundation, structure, and building exterior contractors } \\ 3.38 & 2372 & \text { Land subdivision } \\ 3.24 & 4882 & \text { Support activities for rail transportation } \\ 3.07 & 3391 & \text { Medical equipment and supplies manufacturing } \\ 3.07 & 3169 & \text { Other leather and allied product manufacturing } \\ 3.05 & 2383 & \text { Building finishing contractors } \\ 2.99 & 493 & \text { Warehousing and storage } \\ 2.99 & 4931 & \text { Warehousing and storage } \\ 2.72 & 3271 & \text { Clay product and refractory manufacturing } \\ 2.66 & 3279 & \text { Other nonmetallic mineral product manufacturing } \\ 2.60 & 5312 & \text { Offices of real estate agents and brokers } \\ 2.58 & 6239 & \text { Other residential care facilities } \\ 2.53 & 339 & \text { Miscellaneous manufacturing } \\ 2.40 & 4884 & \text { Support activities for road transportation } \\ 2.36 & 3121 & \text { Beverage manufacturing } \\ 2.35 & 713 & \text { Amusement, gambling, and recreation industries } \\ 2.35 & 5622 & \text { Waste treatment and disposal } \\ 2.29 & 721 & \text { Accommodation } \\ 2.28 & 7211 & \text { Traveler accommodation } \\ 2.23 & 238 & \text { Specialty trade contractors } \\ 2.19 & 3219 & \text { Other wood product manufacturing } \\ 2.19 & 3369 & \text { Other transportation equipment manufacturing } \\ & & \\ \end{array}$




\begin{tabular}{|c|c|c|}
\hline 2.11 & 1151 & Support activities for crop production \\
\hline 2.10 & 4521 & Department stores \\
\hline 2.08 & 312 & Beverage and tobacco product manufacturing \\
\hline 2.06 & 4412 & Other motor vehicle dealers \\
\hline 2.04 & 3399 & Other miscellaneous manufacturing \\
\hline 2.02 & 4922 & Local messengers and local delivery \\
\hline 2.00 & 23 & Construction \\
\hline 1.98 & 7139 & Other amusement and recreation industries \\
\hline 1.98 & 2389 & Other specialty trade contractors \\
\hline 1.93 & 237 & Heavy and civil engineering construction \\
\hline 1.92 & 2371 & Utility system construction \\
\hline 1.90 & 2379 & Other heavy and civil engineering construction \\
\hline 1.85 & 71 & Arts, entertainment, and recreation \\
\hline 1.77 & 4851 & Urban transit systems \\
\hline 1.72 & 3273 & Cement and concrete product manufacturing \\
\hline 1.72 & 327 & Nonmetallic mineral product manufacturing \\
\hline 1.69 & 5324 & Machinery and equipment rental and leasing \\
\hline 1.69 & 2212 & Natural gas distribution \\
\hline 1.68 & 3261 & Plastics product manufacturing \\
\hline 1.66 & 2373 & Highway, street, and bridge construction \\
\hline 1.65 & 115 & Support activities for agriculture and forestry \\
\hline 1.65 & 3324 & Boiler, tank, and shipping container manufacturing \\
\hline 1.58 & 2361 & Residential building construction \\
\hline 1.55 & 4421 & Furniture stores \\
\hline 1.49 & 8111 & Automotive repair and maintenance \\
\hline 1.48 & 3323 & Architectural and structural metals manufacturing \\
\hline 1.48 & 5617 & Services to buildings and dwellings \\
\hline 1.48 & 321 & Wood product manufacturing \\
\hline 1.47 & 4481 & Clothing stores \\
\hline 1.45 & 7222 & Limited-service eating places \\
\hline 1.44 & 4451 & Grocery stores \\
\hline 1.44 & 3329 & Other fabricated metal product manufacturing \\
\hline 1.44 & 3333 & Commercial and service industry machinery manufacturing \\
\hline 1.43 & 72 & Accommodation and food services \\
\hline 1.42 & 443 & Electronics and appliance stores \\
\hline 1.42 & 4431 & Electronics and appliance stores \\
\hline 1.42 & 448 & Clothing and clothing accessories stores \\
\hline 1.42 & 316 & Leather and allied product manufacturing \\
\hline 1.42 & 4482 & Shoe stores \\
\hline 1.42 & 326 & Plastics and rubber products manufacturing \\
\hline 1.41 & 442 & Furniture and home furnishings stores \\
\hline 1.41 & 441 & Motor vehicle and parts dealers \\
\hline 1.40 & 452 & General merchandise stores \\
\hline 1.39 & 4541 & Electronic shopping and mail-order houses \\
\hline 1.39 & 445 & Food and beverage stores \\
\hline
\end{tabular}




$\begin{array}{lcl}1.38 & 4244 & \text { Grocery and related product merchant wholesalers } \\ 1.37 & 6212 & \text { Offices of dentists } \\ 1.36 & 4413 & \text { Automotive parts, accessories, and tire stores } \\ 1.36 & 236 & \text { Construction of buildings } \\ 1.35 & 3313 & \text { Alumina and aluminum production and processing } \\ 1.35 & 3114 & \text { Fruit and vegetable preserving and specialty food manufacturing } \\ 1.34 & 4411 & \text { Automobile dealers } \\ 1.34 & 3344 & \text { Semiconductor and other electronic component manufacturing } \\ 1.33 & 2382 & \text { Building equipment contractors } \\ 1.33 & 5322 & \text { Consumer goods rental } \\ 1.32 & 531 & \text { Real estate } \\ 1.31 & 3254 & \text { Pharmaceutical and medicine manufacturing } \\ 1.30 & 44 & \text { Retail trade } \\ 1.29 & 425 & \text { Wholesale electronic markets and agents and brokers } \\ 1.29 & 4251 & \text { Wholesale electronic markets and agents and brokers } \\ 1.29 & 4532 & \text { Office supplies, stationery, and gift stores } \\ 1.29 & 3252 & \text { Resin, rubber, and artificial fibers mfg. } \\ 1.28 & 4422 & \text { Home furnishings stores } \\ 1.28 & 53 & \text { Real estate and rental and leasing } \\ 1.27 & 5616 & \text { Investigation and security services } \\ 1.27 & 3325 & \text { Hardware manufacturing } \\ 1.27 & 5629 & \text { Remediation and other waste management services } \\ 1.26 & 4452 & \text { Specialty food stores } \\ 1.26 & 1141 & \text { Fishing } \\ 1.26 & 4231 & \text { Motor vehicle and parts merchant wholesalers } \\ 1.26 & 722 & \text { Food services and drinking places } \\ 1.25 & 562 & \text { Waste management and remediation services }\end{array}$

2007 NAICS

STEST

12.50

3.38

2.86

2.59

2.41

2.38

2.36

2.27

2.23

2.05

1.99

1.98

1.95

1.89 code

2121

3362

3325

2379

3212

2371

3369

3365

2212

2389

3324

3253

3311

237

\section{Description}

Coal mining

Motor vehicle body and trailer manufacturing

Hardware manufacturing

Other heavy and civil engineering construction

Veneer, plywood, and engineered wood product manufacturing

Utility system construction

Other transportation equipment manufacturing

Railroad rolling stock manufacturing

Natural gas distribution

Other specialty trade contractors

Boiler, tank, and shipping container manufacturing

Agricultural chemical mfg.

Iron and steel mills and ferroalloy manufacturing

Heavy and civil engineering construction 


\begin{tabular}{|c|c|c|}
\hline 1.82 & 4412 & Other motor vehicle dealers \\
\hline 1.79 & 4884 & Support activities for road transportation \\
\hline 1.76 & 336 & Transportation equipment manufacturing \\
\hline 1.75 & 1152 & Support activities for animal production \\
\hline 1.73 & 212 & Mining (except oil and gas) \\
\hline 1.70 & 4521 & Department stores \\
\hline 1.69 & 2381 & Foundation, structure, and building exterior contractors \\
\hline 1.67 & 2123 & Nonmetallic mineral mining and quarrying \\
\hline 1.67 & 3274 & Lime and gypsum product manufacturing \\
\hline 1.65 & 3273 & Cement and concrete product manufacturing \\
\hline 1.64 & 3279 & Other nonmetallic mineral product manufacturing \\
\hline 1.64 & 3252 & Resin, rubber, and artificial fibers $\mathrm{mfg}$. \\
\hline 1.62 & 3363 & Motor vehicle parts manufacturing \\
\hline 1.62 & 238 & Specialty trade contractors \\
\hline 1.60 & 4881 & Support activities for air transportation \\
\hline 1.59 & 5617 & Services to buildings and dwellings \\
\hline 1.55 & 3331 & Agriculture, construction, and mining machinery manufacturing \\
\hline 1.55 & 4842 & Specialized freight trucking \\
\hline 1.55 & 321 & Wood product manufacturing \\
\hline 1.55 & 2382 & Building equipment contractors \\
\hline 1.53 & 484 & Truck transportation \\
\hline 1.52 & 7212 & RV (recreational vehicle) parks and recreational camps \\
\hline 1.51 & 4841 & General freight trucking \\
\hline 1.51 & 3219 & Other wood product manufacturing \\
\hline 1.50 & 7112 & Spectator sports \\
\hline 1.49 & 7132 & Gambling industries \\
\hline 1.48 & 327 & Nonmetallic mineral product manufacturing \\
\hline 1.48 & 2362 & Nonresidential building construction \\
\hline 1.47 & 2122 & Metal ore mining \\
\hline 1.47 & 4852 & Interurban and rural bus transportation \\
\hline 1.47 & 4882 & Support activities for rail transportation \\
\hline 1.47 & 3261 & Plastics product manufacturing \\
\hline 1.47 & 4233 & Lumber and other construction materials merchant wholesalers \\
\hline 1.46 & 23 & Construction \\
\hline 1.46 & 2372 & Land subdivision \\
\hline 1.46 & 2383 & Building finishing contractors \\
\hline 1.46 & 6239 & Other residential care facilities \\
\hline 1.45 & 4413 & Automotive parts, accessories, and tire stores \\
\hline 1.43 & 6232 & Residential mental health facilities \\
\hline 1.42 & 3379 & Other furniture related product manufacturing \\
\hline 1.42 & 3323 & Architectural and structural metals manufacturing \\
\hline 1.42 & 3334 & HVAC and commercial refrigeration equipment \\
\hline 1.41 & 3329 & Other fabricated metal product manufacturing \\
\hline 1.41 & 3111 & Animal food manufacturing \\
\hline 1.41 & 441 & Motor vehicle and parts dealers \\
\hline
\end{tabular}




$\begin{array}{lcl}1.40 & 4482 & \text { Shoe stores } \\ 1.40 & 8113 & \text { Commercial machinery repair and maintenance } \\ 1.39 & 452 & \text { General merchandise stores } \\ 1.38 & 5323 & \text { General rental centers } \\ 1.38 & 326 & \text { Plastics and rubber products manufacturing } \\ 1.37 & 5324 & \text { Machinery and equipment rental and leasing } \\ 1.34 & 2373 & \text { Highway, street, and bridge construction } \\ 1.34 & 5629 & \text { Remediation and other waste management services } \\ 1.32 & 4542 & \text { Vending machine operators } \\ 1.31 & 447 & \text { Gasoline stations } \\ 1.31 & 4471 & \text { Gasoline stations } \\ 1.31 & 4854 & \text { School and employee bus transportation } \\ 1.30 & 4421 & \text { Furniture stores } \\ 1.29 & 4539 & \text { Other miscellaneous store retailers } \\ 1.29 & 5312 & \text { Offices of real estate agents and brokers } \\ 1.29 & 4237 & \text { Hardware and plumbing merchant wholesalers } \\ 1.29 & 3366 & \text { Ship and boat building } \\ 1.28 & 3352 & \text { Household appliance manufacturing } \\ 1.27 & 532 & \text { Rental and leasing services } \\ 1.27 & 5322 & \text { Consumer goods rental } \\ 1.26 & 8122 & \text { Death care services } \\ 1.26 & 3271 & \text { Clay product and refractory manufacturing } \\ 1.26 & 7139 & \text { Other amusement and recreation industries } \\ 1.26 & 3333 & \text { Commercial and service industry machinery manufacturing } \\ 1.25 & 713 & \text { Amusement, gambling, and recreation industries } \\ 1.25 & 3339 & \text { Other general purpose machinery manufacturing } \\ 1.25 & 3326 & \text { Spring and wire product manufacturing } \\ & & \end{array}$

\section{NAICS}

USEST

code

$4.74 \quad 3369$

$3.51 \quad 3325$

$2.81 \quad 3362$

$2.44 \quad 4884$

$2.15 \quad 6239$

$1.91 \quad 3379$

$1.91 \quad 3253$

$1.90 \quad 1152$

$1.87 \quad 3274$

$1.86 \quad 2379$

$1.84 \quad 336$

$1.80 \quad 3333$

$1.72 \quad 4521$

$1.71 \quad 7112$

\section{Description}

Other transportation equipment manufacturing

Hardware manufacturing

Motor vehicle body and trailer manufacturing

Support activities for road transportation

Other residential care facilities

Other furniture related product manufacturing

Agricultural chemical mfg.

Support activities for animal production

Lime and gypsum product manufacturing

Other heavy and civil engineering construction

Transportation equipment manufacturing

Commercial and service industry machinery manufacturing

Department stores

Spectator sports 


\begin{tabular}{|c|c|c|}
\hline 1.64 & 5324 & Machinery and equipment rental and leasing \\
\hline 1.64 & 3364 & Aerospace product and parts manufacturing \\
\hline 1.62 & 2212 & Natural gas distribution \\
\hline 1.59 & 3363 & Motor vehicle parts manufacturing \\
\hline 1.55 & 2389 & Other specialty trade contractors \\
\hline 1.55 & 525 & Funds, trusts, and other financial vehicles \\
\hline 1.55 & 5259 & Other investment pools and funds \\
\hline 1.55 & 3256 & Soap, cleaning compound, and toilet preparation manufacturing \\
\hline 1.55 & 3311 & Iron and steel mills and ferroalloy manufacturing \\
\hline 1.54 & 3324 & Boiler, tank, and shipping container manufacturing \\
\hline 1.53 & 4881 & Support activities for air transportation \\
\hline 1.51 & 2371 & Utility system construction \\
\hline 1.46 & 3212 & Veneer, plywood, and engineered wood product manufacturing \\
\hline 1.44 & 2372 & Land subdivision \\
\hline 1.43 & 6233 & Community care facilities for the elderly \\
\hline 1.41 & 3261 & Plastics product manufacturing \\
\hline 1.41 & 4482 & Shoe stores \\
\hline 1.41 & 2383 & Building finishing contractors \\
\hline 1.40 & 5312 & Offices of real estate agents and brokers \\
\hline 1.40 & 237 & Heavy and civil engineering construction \\
\hline 1.39 & 5616 & Investigation and security services \\
\hline 1.39 & 2362 & Nonresidential building construction \\
\hline 1.39 & 3121 & Beverage manufacturing \\
\hline 1.39 & 7222 & Limited-service eating places \\
\hline 1.38 & 115 & Support activities for agriculture and forestry \\
\hline 1.38 & 5611 & Office administrative services \\
\hline 1.37 & 3346 & Manufacturing and reproducing magnetic and optical media \\
\hline 1.37 & 238 & Specialty trade contractors \\
\hline 1.35 & 312 & Beverage and tobacco product manufacturing \\
\hline 1.35 & 4231 & Motor vehicle and parts merchant wholesalers \\
\hline 1.35 & 4237 & Hardware and plumbing merchant wholesalers \\
\hline 1.34 & 4412 & Other motor vehicle dealers \\
\hline 1.33 & 6212 & Offices of dentists \\
\hline 1.33 & 1151 & Support activities for crop production \\
\hline 1.32 & 326 & Plastics and rubber products manufacturing \\
\hline 1.32 & 4481 & Clothing stores \\
\hline 1.32 & 3323 & Architectural and structural metals manufacturing \\
\hline 1.30 & 2381 & Foundation, structure, and building exterior contractors \\
\hline 1.30 & 2382 & Building equipment contractors \\
\hline 1.30 & 4855 & Charter bus industry \\
\hline 1.29 & 5617 & Services to buildings and dwellings \\
\hline 1.29 & 5223 & Activities related to credit intermediation \\
\hline 1.29 & 3252 & Resin, rubber, and artificial fibers $\mathrm{mfg}$. \\
\hline 1.28 & 4242 & Drugs and druggists' sundries merchant wholesalers \\
\hline 1.28 & 3329 & Other fabricated metal product manufacturing \\
\hline
\end{tabular}




$\begin{array}{lcl}1.28 & 448 & \text { Clothing and clothing accessories stores } \\ 1.28 & 493 & \text { Warehousing and storage } \\ 1.28 & 4931 & \text { Warehousing and storage } \\ 1.27 & 3334 & \text { HVAC and commercial refrigeration equipment } \\ 1.27 & 23 & \text { Construction } \\ 1.27 & 5313 & \text { Activities related to real estate } \\ 1.26 & 8112 & \text { Electronic and precision equipment repair and maintenance } \\ 1.25 & 3399 & \text { Other miscellaneous manufacturing } \\ 1.25 & 3322 & \text { Cutlery and handtool manufacturing } \\ 1.25 & 3352 & \text { Household appliance manufacturing }\end{array}$

San Bernardino County

\begin{tabular}{rc} 
STEMP & code \\
14.02 & 3311 \\
5.86 & 2122 \\
5.17 & 3273 \\
5.07 & 3313 \\
4.67 & 493 \\
4.67 & 4931 \\
4.29 & 4841 \\
4.18 & 3212 \\
4.00 & 6222 \\
3.89 & 331 \\
3.68 & 484 \\
3.24 & 1131 \\
3.12 & 212 \\
3.09 & 3334 \\
3.09 & 3371 \\
3.08 & 3351 \\
3.05 & 327 \\
3.04 & 3251 \\
2.94 & 3312 \\
2.92 & 7212 \\
2.91 & 2123 \\
2.91 & 4854 \\
2.90 & 2379 \\
2.84 & 4921 \\
2.81 & 3261 \\
2.81 & 4882 \\
2.79 & 326 \\
2.76 & 3253 \\
2.72 & 4842 \\
& \\
\hline
\end{tabular}

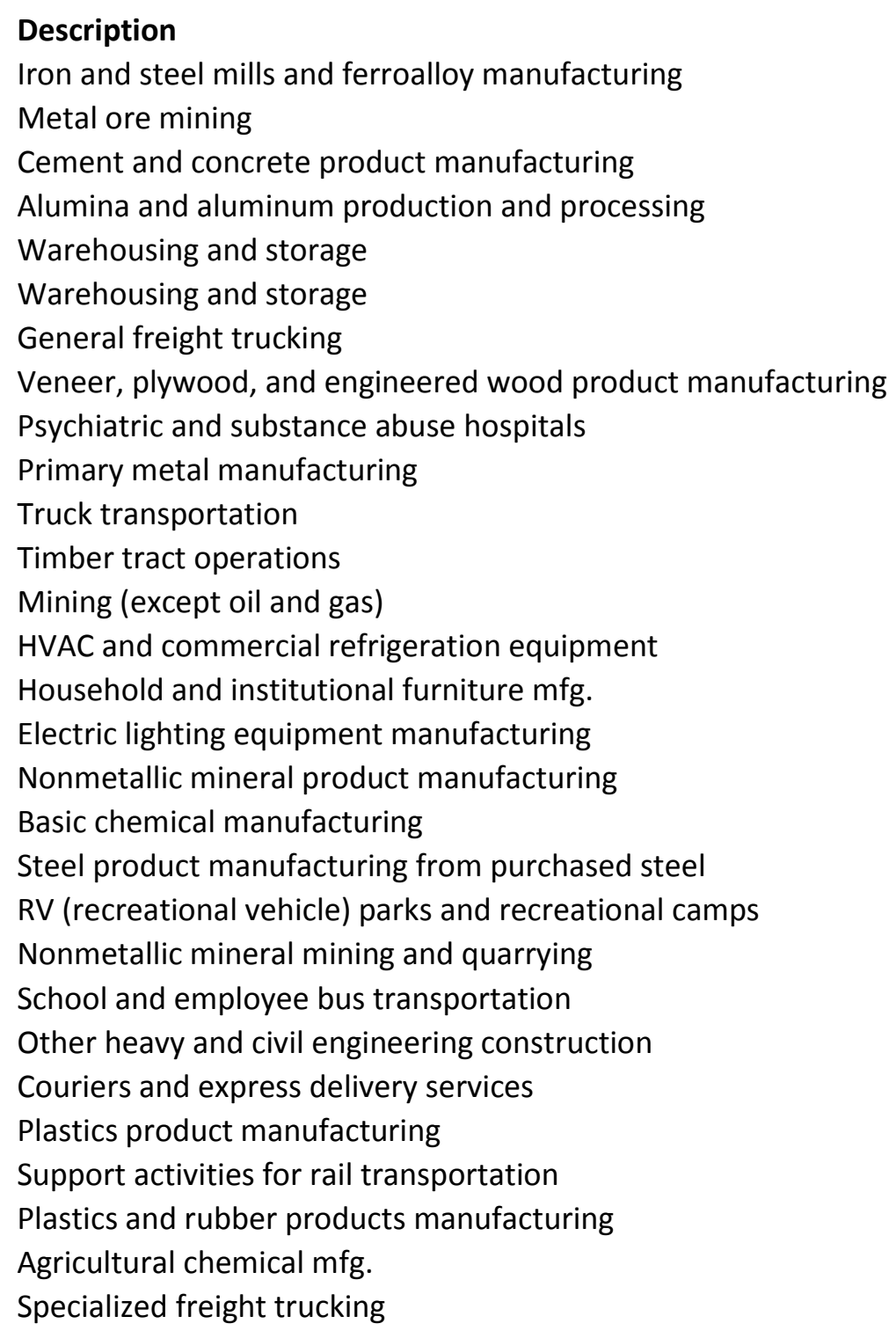




\begin{tabular}{|c|c|c|}
\hline 2.65 & 3326 & Spring and wire product manufacturing \\
\hline 2.64 & 3262 & Rubber product manufacturing \\
\hline 2.63 & 492 & Couriers and messengers \\
\hline 2.60 & 337 & Furniture and related product manufacturing \\
\hline 2.55 & 4231 & Motor vehicle and parts merchant wholesalers \\
\hline 2.54 & 4884 & Support activities for road transportation \\
\hline 2.52 & 3321 & Forging and stamping \\
\hline 2.47 & 3323 & Architectural and structural metals manufacturing \\
\hline 2.45 & 4233 & Lumber and other construction materials merchant wholesalers \\
\hline 2.45 & 2212 & Natural gas distribution \\
\hline 2.41 & 6115 & Technical and trade schools \\
\hline 2.35 & 4412 & Other motor vehicle dealers \\
\hline 2.25 & 3372 & Office furniture (including fixtures) manufacturing \\
\hline 2.18 & 3329 & Other fabricated metal product manufacturing \\
\hline 2.12 & 3252 & Resin, rubber, and artificial fibers $\mathrm{mfg}$. \\
\hline 1.98 & 5612 & Facilities support services \\
\hline 1.94 & 3255 & Paint, coating, and adhesive manufacturing \\
\hline 1.92 & 321 & Wood product manufacturing \\
\hline 1.92 & 48 & Transportation and warehousing \\
\hline 1.89 & 3363 & Motor vehicle parts manufacturing \\
\hline 1.88 & 2373 & Highway, street, and bridge construction \\
\hline 1.88 & 3362 & Motor vehicle body and trailer manufacturing \\
\hline 1.86 & 4235 & Metal and mineral (except petroleum) merchant wholesalers \\
\hline 1.81 & 4862 & Pipeline transportation of natural gas \\
\hline 1.80 & 7132 & Gambling industries \\
\hline 1.80 & 3221 & Pulp, paper, and paperboard mills \\
\hline 1.77 & 3117 & Seafood product preparation and packaging \\
\hline 1.76 & 332 & Fabricated metal product manufacturing \\
\hline 1.74 & 8114 & Personal and household goods repair and maintenance \\
\hline 1.74 & 447 & Gasoline stations \\
\hline 1.74 & 4471 & Gasoline stations \\
\hline 1.73 & 3131 & Fiber, yarn, and thread mills \\
\hline 1.71 & 6243 & Vocational rehabilitation services \\
\hline 1.69 & 3219 & Other wood product manufacturing \\
\hline 1.69 & 4413 & Automotive parts, accessories, and tire stores \\
\hline 1.68 & 2213 & Water, sewage and other systems \\
\hline 1.65 & 5611 & Office administrative services \\
\hline 1.64 & 4852 & Interurban and rural bus transportation \\
\hline 1.64 & 4245 & Farm product raw material merchant wholesalers \\
\hline 1.64 & 32 & Manufacturing \\
\hline 1.62 & 2389 & Other specialty trade contractors \\
\hline 1.59 & 4241 & Paper and paper product merchant wholesalers \\
\hline 1.59 & 237 & Heavy and civil engineering construction \\
\hline 1.57 & 2381 & Foundation, structure, and building exterior contractors \\
\hline 1.57 & 22 & Utilities \\
\hline
\end{tabular}




$\begin{array}{lcl}1.57 & 221 & \text { Utilities } \\ 1.57 & 3346 & \text { Manufacturing and reproducing magnetic and optical media } \\ 1.56 & 4881 & \text { Support activities for air transportation } \\ 1.55 & 4521 & \text { Department stores } \\ 1.53 & 452 & \text { General merchandise stores } \\ 1.51 & 8112 & \text { Electronic and precision equipment repair and maintenance } \\ 1.51 & 6112 & \text { Junior colleges } \\ 1.51 & 2371 & \text { Utility system construction } \\ 1.49 & 4237 & \text { Hardware and plumbing merchant wholesalers } \\ 1.49 & 7213 & \text { Rooming and boarding houses } \\ 1.47 & 441 & \text { Motor vehicle and parts dealers } \\ 1.47 & 4529 & \text { Other general merchandise stores } \\ 1.46 & 8113 & \text { Commercial machinery repair and maintenance } \\ 1.44 & 811 & \text { Repair and maintenance } \\ 1.44 & 3366 & \text { Ship and boat building } \\ 1.43 & 3315 & \text { Foundries } \\ 1.43 & 6239 & \text { Other residential care facilities } \\ 1.43 & 6219 & \text { Other ambulatory health care services } \\ 1.42 & 4247 & \text { Petroleum and petroleum products merchant wholesalers } \\ 1.42 & 4511 & \text { Sporting goods, hobby, and musical instrument stores } \\ 1.41 & 8111 & \text { Automotive repair and maintenance } \\ 1.41 & 3272 & \text { Glass and glass product manufacturing } \\ 1.39 & 622 & \text { Hospitals } \\ 1.37 & 7222 & \text { Limited-service eating places } \\ 1.33 & 3327 & \text { Machine shops and threaded product mfg. } \\ 1.33 & 3118 & \text { Bakeries and tortilla manufacturing } \\ 1.32 & 4232 & \text { Furniture and home furnishing merchant wholesalers } \\ 1.32 & 6221 & \text { General medical and surgical hospitals } \\ 1.31 & 4441 & \text { Building material and supplies dealers } \\ 1.30 & 3141 & \text { Textile furnishings mills } \\ 1.29 & 444 & \text { Building material and garden equipment and supplies dealers } \\ 1.29 & 4411 & \text { Automobile dealers } \\ 1.29 & 5622 & \text { Waste treatment and disposal } \\ 1.29 & 486 & \text { Pipeline transportation } \\ 1.26 & 4238 & \text { Machinery, equipment, and supplies merchant wholesalers } \\ & & \\ & & \end{array}$

\section{NAICS}

USEMP code

$4.74 \quad 3351$

$4.63 \quad 3273$

$4.59 \quad 493$

$4.59 \quad 4931$

$4.43 \quad 4884$

$4.31 \quad 2212$

\section{Description}

Electric lighting equipment manufacturing

Cement and concrete product manufacturing

Warehousing and storage

Warehousing and storage

Support activities for road transportation

Natural gas distribution 


\begin{tabular}{|c|c|c|}
\hline 3.92 & 7132 & Gambling industries \\
\hline 3.92 & 3346 & Manufacturing and reproducing magnetic and optical media \\
\hline 3.47 & 7212 & RV (recreational vehicle) parks and recreational camps \\
\hline 3.15 & 3311 & Iron and steel mills and ferroalloy manufacturing \\
\hline 3.02 & 4921 & Couriers and express delivery services \\
\hline 3.00 & 6222 & Psychiatric and substance abuse hospitals \\
\hline 3.00 & 6115 & Technical and trade schools \\
\hline 2.92 & 492 & Couriers and messengers \\
\hline 2.83 & 4231 & Motor vehicle and parts merchant wholesalers \\
\hline 2.80 & 4841 & General freight trucking \\
\hline 2.67 & 3371 & Household and institutional furniture $\mathrm{mfg}$. \\
\hline 2.64 & 2379 & Other heavy and civil engineering construction \\
\hline 2.61 & 484 & Truck transportation \\
\hline 2.59 & 327 & Nonmetallic mineral product manufacturing \\
\hline 2.44 & 3313 & Alumina and aluminum production and processing \\
\hline 2.28 & 337 & Furniture and related product manufacturing \\
\hline 2.25 & 4842 & Specialized freight trucking \\
\hline 2.18 & 8112 & Electronic and precision equipment repair and maintenance \\
\hline 2.17 & 4882 & Support activities for rail transportation \\
\hline 2.16 & 3323 & Architectural and structural metals manufacturing \\
\hline 2.16 & 4521 & Department stores \\
\hline 2.13 & 4412 & Other motor vehicle dealers \\
\hline 2.10 & 4233 & Lumber and other construction materials merchant wholesalers \\
\hline 2.06 & 4232 & Furniture and home furnishing merchant wholesalers \\
\hline 2.04 & 3261 & Plastics product manufacturing \\
\hline 1.99 & 2381 & Foundation, structure, and building exterior contractors \\
\hline 1.95 & 1131 & Timber tract operations \\
\hline 1.89 & 326 & Plastics and rubber products manufacturing \\
\hline 1.84 & 4237 & Hardware and plumbing merchant wholesalers \\
\hline 1.80 & 5611 & Office administrative services \\
\hline 1.79 & 4239 & Miscellaneous durable goods merchant wholesalers \\
\hline 1.77 & 3372 & Office furniture (including fixtures) manufacturing \\
\hline 1.75 & 2123 & Nonmetallic mineral mining and quarrying \\
\hline 1.74 & 3391 & Medical equipment and supplies manufacturing \\
\hline 1.72 & 6239 & Other residential care facilities \\
\hline 1.71 & 3212 & Veneer, plywood, and engineered wood product manufacturing \\
\hline 1.69 & 48 & Transportation and warehousing \\
\hline 1.68 & 2383 & Building finishing contractors \\
\hline 1.68 & 3321 & Forging and stamping \\
\hline 1.67 & 4235 & Metal and mineral (except petroleum) merchant wholesalers \\
\hline 1.66 & 8114 & Personal and household goods repair and maintenance \\
\hline 1.65 & 4241 & Paper and paper product merchant wholesalers \\
\hline 1.63 & 8111 & Automotive repair and maintenance \\
\hline 1.62 & 3118 & Bakeries and tortilla manufacturing \\
\hline 1.59 & 811 & Repair and maintenance \\
\hline
\end{tabular}




\begin{tabular}{|c|c|c|}
\hline 1.58 & 4854 & School and employee bus transportation \\
\hline 1.57 & 3369 & Other transportation equipment manufacturing \\
\hline 1.55 & 3253 & Agricultural chemical mfg. \\
\hline 1.55 & 2389 & Other specialty trade contractors \\
\hline 1.54 & 488 & Support activities for transportation \\
\hline 1.54 & 331 & Primary metal manufacturing \\
\hline 1.52 & 4881 & Support activities for air transportation \\
\hline 1.52 & 4413 & Automotive parts, accessories, and tire stores \\
\hline 1.52 & 2213 & Water, sewage and other systems \\
\hline 1.51 & 713 & Amusement, gambling, and recreation industries \\
\hline 1.51 & 339 & Miscellaneous manufacturing \\
\hline 1.49 & 332 & Fabricated metal product manufacturing \\
\hline 1.47 & 7222 & Limited-service eating places \\
\hline 1.46 & 3327 & Machine shops and threaded product mfg. \\
\hline 1.45 & 3114 & Fruit and vegetable preserving and specialty food manufacturing \\
\hline 1.44 & 423 & Merchant wholesalers, durable goods \\
\hline 1.43 & 7213 & Rooming and boarding houses \\
\hline 1.43 & 3326 & Spring and wire product manufacturing \\
\hline 1.43 & 4511 & Sporting goods, hobby, and musical instrument stores \\
\hline 1.42 & 4244 & Grocery and related product merchant wholesalers \\
\hline 1.37 & 441 & Motor vehicle and parts dealers \\
\hline 1.37 & 3334 & HVAC and commercial refrigeration equipment \\
\hline 1.37 & 5112 & Software publishers \\
\hline 1.35 & 4481 & Clothing stores \\
\hline 1.34 & 2373 & Highway, street, and bridge construction \\
\hline 1.34 & 238 & Specialty trade contractors \\
\hline 1.33 & 3329 & Other fabricated metal product manufacturing \\
\hline 1.32 & 3119 & Other food manufacturing \\
\hline 1.32 & 6243 & Vocational rehabilitation services \\
\hline 1.30 & 3255 & Paint, coating, and adhesive manufacturing \\
\hline 1.30 & 3399 & Other miscellaneous manufacturing \\
\hline 1.30 & 42 & Wholesale trade \\
\hline 1.30 & 4885 & Freight transportation arrangement \\
\hline 1.30 & 4249 & Miscellaneous nondurable goods merchant wholesalers \\
\hline 1.29 & 4922 & Local messengers and local delivery \\
\hline 1.29 & 448 & Clothing and clothing accessories stores \\
\hline 1.27 & 5324 & Machinery and equipment rental and leasing \\
\hline 1.27 & 452 & General merchandise stores \\
\hline 1.26 & 7139 & Other amusement and recreation industries \\
\hline 1.26 & 451 & Sporting goods, hobby, book, and music stores \\
\hline 1.26 & 22 & Utilities \\
\hline 1.26 & 221 & Utilities \\
\hline
\end{tabular}

\section{STEST 2007 NAICS Description}




\section{code}

$6.25 \quad 2122$

$5.32 \quad 4869$

$4.98 \quad 3361$

$4.57 \quad 3311$

$4.29 \quad 3313$

$4.17 \quad 4882$

$4.09 \quad 3221$

$3.91 \quad 4852$

$3.78 \quad 493$

$3.78 \quad 4931$

$3.21 \quad 3362$

$3.15 \quad 3212$

$3.13 \quad 4862$

$3.09 \quad 486$

$3.06 \quad 3262$

$2.95 \quad 3312$

$2.65 \quad 326$

$2.64 \quad 3369$

$2.61 \quad 3251$

$2.60 \quad 3334$

$2.58 \quad 3261$

$2.52 \quad 4841$

$2.50 \quad 2212$

$2.46 \quad 331$

$2.42 \quad 3365$

$2.36 \quad 3273$

$2.33 \quad 3255$

$2.31 \quad 3324$

$2.26 \quad 4854$

$2.26 \quad 3363$

$2.22 \quad 2213$

$2.22 \quad 336$

$2.22 \quad 1131$

$2.18 \quad 3252$

$2.10 \quad 484$

$2.09 \quad 4231$

$2.09 \quad 3259$

$2.08 \quad 3329$

$2.06 \quad 321$

$2.05 \quad 22$

$2.05 \quad 221$

$2.02 \quad 212$

$1.98 \quad 2371$

$1.95 \quad 3219$

Metal ore mining

Other pipeline transportation

Motor vehicle manufacturing

Iron and steel mills and ferroalloy manufacturing

Alumina and aluminum production and processing

Support activities for rail transportation

Pulp, paper, and paperboard mills

Interurban and rural bus transportation

Warehousing and storage

Warehousing and storage

Motor vehicle body and trailer manufacturing

Veneer, plywood, and engineered wood product manufacturing

Pipeline transportation of natural gas

Pipeline transportation

Rubber product manufacturing

Steel product manufacturing from purchased steel

Plastics and rubber products manufacturing

Other transportation equipment manufacturing

Basic chemical manufacturing

HVAC and commercial refrigeration equipment

Plastics product manufacturing

General freight trucking

Natural gas distribution

Primary metal manufacturing

Railroad rolling stock manufacturing

Cement and concrete product manufacturing

Paint, coating, and adhesive manufacturing

Boiler, tank, and shipping container manufacturing

School and employee bus transportation

Motor vehicle parts manufacturing

Water, sewage and other systems

Transportation equipment manufacturing

Timber tract operations

Resin, rubber, and artificial fibers mfg.

Truck transportation

Motor vehicle and parts merchant wholesalers

Other chemical product and preparation manufacturing

Other fabricated metal product manufacturing

Wood product manufacturing

Utilities

Utilities

Mining (except oil and gas)

Utility system construction

Other wood product manufacturing 


\begin{tabular}{|c|c|c|}
\hline 1.91 & 4235 & Metal and mineral (except petroleum) merchant wholesalers \\
\hline 1.88 & 3323 & Architectural and structural metals manufacturing \\
\hline 1.88 & 7212 & RV (recreational vehicle) parks and recreational camps \\
\hline 1.86 & 3321 & Forging and stamping \\
\hline 1.85 & 4884 & Support activities for road transportation \\
\hline 1.85 & 6112 & Junior colleges \\
\hline 1.84 & 322 & Paper manufacturing \\
\hline 1.83 & 8113 & Commercial machinery repair and maintenance \\
\hline 1.83 & 3326 & Spring and wire product manufacturing \\
\hline 1.79 & 4233 & Lumber and other construction materials merchant wholesalers \\
\hline 1.78 & 2123 & Nonmetallic mineral mining and quarrying \\
\hline 1.77 & 3274 & Lime and gypsum product manufacturing \\
\hline 1.75 & 3315 & Foundries \\
\hline 1.72 & 3335 & Metalworking machinery manufacturing \\
\hline 1.71 & 3222 & Converted paper product manufacturing \\
\hline 1.70 & 48 & Transportation and warehousing \\
\hline 1.70 & 327 & Nonmetallic mineral product manufacturing \\
\hline 1.69 & 324 & Petroleum and coal products manufacturing \\
\hline 1.69 & 3241 & Petroleum and coal products manufacturing \\
\hline 1.68 & 4521 & Department stores \\
\hline 1.67 & 4413 & Automotive parts, accessories, and tire stores \\
\hline 1.67 & 2389 & Other specialty trade contractors \\
\hline 1.67 & 2211 & Electric power generation, transmission and distribution \\
\hline 1.66 & 5621 & Waste collection \\
\hline 1.65 & 4412 & Other motor vehicle dealers \\
\hline 1.63 & 6222 & Psychiatric and substance abuse hospitals \\
\hline 1.63 & 5323 & General rental centers \\
\hline 1.63 & 3372 & Office furniture (including fixtures) manufacturing \\
\hline 1.62 & 4237 & Hardware and plumbing merchant wholesalers \\
\hline 1.62 & 441 & Motor vehicle and parts dealers \\
\hline 1.62 & 2379 & Other heavy and civil engineering construction \\
\hline 1.60 & 2373 & Highway, street, and bridge construction \\
\hline 1.60 & 3339 & Other general purpose machinery manufacturing \\
\hline 1.60 & 332 & Fabricated metal product manufacturing \\
\hline 1.59 & 3211 & Sawmills and wood preservation \\
\hline 1.59 & 2381 & Foundation, structure, and building exterior contractors \\
\hline 1.58 & 3253 & Agricultural chemical mfg. \\
\hline 1.56 & 452 & General merchandise stores \\
\hline 1.56 & 6221 & General medical and surgical hospitals \\
\hline 1.55 & 32 & Manufacturing \\
\hline 1.55 & 6115 & Technical and trade schools \\
\hline 1.54 & 622 & Hospitals \\
\hline 1.54 & 4411 & Automobile dealers \\
\hline 1.52 & 325 & Chemical manufacturing \\
\hline 1.52 & 237 & Heavy and civil engineering construction \\
\hline
\end{tabular}




\begin{tabular}{|c|c|c|}
\hline 1.52 & 3331 & Agriculture, construction, and mining machinery manufacturing \\
\hline 1.51 & 4842 & Specialized freight trucking \\
\hline 1.51 & 3379 & Other furniture related product manufacturing \\
\hline 1.51 & 4529 & Other general merchandise stores \\
\hline 1.50 & 5321 & Automotive equipment rental and leasing \\
\hline 1.50 & 6232 & Residential mental health facilities \\
\hline 1.49 & 3327 & Machine shops and threaded product mfg. \\
\hline 1.46 & 447 & Gasoline stations \\
\hline 1.46 & 4471 & Gasoline stations \\
\hline 1.44 & 333 & Machinery manufacturing \\
\hline 1.43 & 4238 & Machinery, equipment, and supplies merchant wholesalers \\
\hline 1.40 & 4247 & Petroleum and petroleum products merchant wholesalers \\
\hline 1.39 & 4246 & Chemical and allied products merchant wholesalers \\
\hline 1.39 & 6214 & Outpatient care centers \\
\hline 1.38 & 8111 & Automotive repair and maintenance \\
\hline 1.38 & 4453 & Beer, wine, and liquor stores \\
\hline 1.38 & 811 & Repair and maintenance \\
\hline 1.37 & 5322 & Consumer goods rental \\
\hline 1.37 & 4881 & Support activities for air transportation \\
\hline 1.37 & 238 & Specialty trade contractors \\
\hline 1.36 & 3352 & Household appliance manufacturing \\
\hline 1.36 & 4812 & Nonscheduled air transportation \\
\hline 1.35 & 2362 & Nonresidential building construction \\
\hline 1.35 & 6113 & Colleges, universities, and professional schools \\
\hline 1.35 & 6216 & Home health care services \\
\hline 1.35 & 488 & Support activities for transportation \\
\hline 1.35 & 3113 & Sugar and confectionery product manufacturing \\
\hline 1.34 & 337 & Furniture and related product manufacturing \\
\hline 1.34 & 3271 & Clay product and refractory manufacturing \\
\hline 1.33 & 532 & Rental and leasing services \\
\hline 1.33 & 562 & Waste management and remediation services \\
\hline 1.33 & 4542 & Vending machine operators \\
\hline 1.32 & 3346 & Manufacturing and reproducing magnetic and optical media \\
\hline 1.31 & 4232 & Furniture and home furnishing merchant wholesalers \\
\hline 1.30 & 4921 & Couriers and express delivery services \\
\hline 1.30 & 2382 & Building equipment contractors \\
\hline 1.30 & 423 & Merchant wholesalers, durable goods \\
\hline 1.30 & 3364 & Aerospace product and parts manufacturing \\
\hline 1.29 & 4859 & Other transit and ground passenger transportation \\
\hline 1.27 & 5616 & Investigation and security services \\
\hline 1.27 & 6239 & Other residential care facilities \\
\hline 1.27 & 3325 & Hardware manufacturing \\
\hline 1.27 & 6223 & Specialty (except psychiatric and substance abuse) hospitals \\
\hline 1.27 & 7222 & Limited-service eating places \\
\hline 1.27 & 8131 & Religious organizations \\
\hline
\end{tabular}




$\begin{array}{lcl}1.26 & 492 & \text { Couriers and messengers } \\ 1.26 & 23 & \text { Construction } \\ 1.26 & 4482 & \text { Shoe stores } \\ 1.25 & 3371 & \text { Household and institutional furniture mfg. }\end{array}$

\begin{tabular}{|c|c|c|}
\hline \multicolumn{3}{|c|}{2007 NAICS } \\
\hline USEST & code & Description \\
\hline 5.49 & 3361 & Motor vehicle manufacturing \\
\hline 5.32 & 3369 & Other transportation equipment manufacturing \\
\hline 3.97 & 493 & Warehousing and storage \\
\hline 3.97 & 4931 & Warehousing and storage \\
\hline 3.87 & 3313 & Alumina and aluminum production and processing \\
\hline 3.62 & 3311 & Iron and steel mills and ferroalloy manufacturing \\
\hline 2.91 & 3346 & Manufacturing and reproducing magnetic and optical media \\
\hline 2.84 & 2122 & Metal ore mining \\
\hline 2.77 & 3262 & Rubber product manufacturing \\
\hline 2.67 & 3362 & Motor vehicle body and trailer manufacturing \\
\hline 2.52 & 326 & Plastics and rubber products manufacturing \\
\hline 2.52 & 4884 & Support activities for road transportation \\
\hline 2.48 & 3261 & Plastics product manufacturing \\
\hline 2.43 & 3255 & Paint, coating, and adhesive manufacturing \\
\hline 2.37 & 4231 & Motor vehicle and parts merchant wholesalers \\
\hline 2.36 & 4852 & Interurban and rural bus transportation \\
\hline 2.36 & 3343 & Audio and video equipment manufacturing \\
\hline 2.34 & 3334 & HVAC and commercial refrigeration equipment \\
\hline 2.32 & 336 & Transportation equipment manufacturing \\
\hline 2.22 & 3312 & Steel product manufacturing from purchased steel \\
\hline 2.22 & 3363 & Motor vehicle parts manufacturing \\
\hline 2.13 & 3351 & Electric lighting equipment manufacturing \\
\hline 2.13 & 4869 & Other pipeline transportation \\
\hline 2.09 & 331 & Primary metal manufacturing \\
\hline 2.08 & 6112 & Junior colleges \\
\hline 2.03 & 3379 & Other furniture related product manufacturing \\
\hline 2.01 & 3364 & Aerospace product and parts manufacturing \\
\hline 2.01 & 4232 & Furniture and home furnishing merchant wholesalers \\
\hline 2.01 & 3341 & Computer and peripheral equipment manufacturing \\
\hline 1.99 & 3274 & Lime and gypsum product manufacturing \\
\hline 1.98 & 3114 & Fruit and vegetable preserving and specialty food manufacturing \\
\hline 1.92 & 3212 & Veneer, plywood, and engineered wood product manufacturing \\
\hline 1.90 & 4841 & General freight trucking \\
\hline 1.90 & 4235 & Metal and mineral (except petroleum) merchant wholesalers \\
\hline 1.89 & 3329 & Other fabricated metal product manufacturing \\
\hline 1.88 & 3259 & Other chemical product and preparation manufacturing \\
\hline 1.87 & 6239 & Other residential care facilities \\
\hline
\end{tabular}




\begin{tabular}{|c|c|c|}
\hline 1.84 & 3321 & Forging and stamping \\
\hline 1.82 & 3221 & Pulp, paper, and paperboard mills \\
\hline 1.82 & 2212 & Natural gas distribution \\
\hline 1.81 & 2213 & Water, sewage and other systems \\
\hline 1.80 & 4882 & Support activities for rail transportation \\
\hline 1.79 & 3324 & Boiler, tank, and shipping container manufacturing \\
\hline 1.74 & 3323 & Architectural and structural metals manufacturing \\
\hline 1.74 & 6115 & Technical and trade schools \\
\hline 1.72 & 3372 & Office furniture (including fixtures) manufacturing \\
\hline 1.71 & 3252 & Resin, rubber, and artificial fibers $\mathrm{mfg}$. \\
\hline 1.70 & 4521 & Department stores \\
\hline 1.69 & 4237 & Hardware and plumbing merchant wholesalers \\
\hline 1.67 & 3326 & Spring and wire product manufacturing \\
\hline 1.66 & 6113 & Colleges, universities, and professional schools \\
\hline 1.65 & 332 & Fabricated metal product manufacturing \\
\hline 1.62 & 3327 & Machine shops and threaded product mfg. \\
\hline 1.61 & 4242 & Drugs and druggists' sundries merchant wholesalers \\
\hline 1.58 & 488 & Support activities for transportation \\
\hline 1.56 & 5223 & Activities related to credit intermediation \\
\hline 1.56 & 3315 & Foundries \\
\hline 1.56 & 322 & Paper manufacturing \\
\hline 1.56 & 3325 & Hardware manufacturing \\
\hline 1.55 & 4249 & Miscellaneous nondurable goods merchant wholesalers \\
\hline 1.53 & 484 & Truck transportation \\
\hline 1.53 & 325 & Chemical manufacturing \\
\hline 1.52 & 3222 & Converted paper product manufacturing \\
\hline 1.52 & 3253 & Agricultural chemical mfg. \\
\hline 1.52 & 5616 & Investigation and security services \\
\hline 1.52 & 423 & Merchant wholesalers, durable goods \\
\hline 1.51 & 3251 & Basic chemical manufacturing \\
\hline 1.50 & 3219 & Other wood product manufacturing \\
\hline 1.48 & 4233 & Lumber and other construction materials merchant wholesalers \\
\hline 1.46 & 5321 & Automotive equipment rental and leasing \\
\hline 1.46 & 3272 & Glass and glass product manufacturing \\
\hline 1.46 & 337 & Furniture and related product manufacturing \\
\hline 1.45 & 3328 & Coating, engraving, heat treating, and allied activities \\
\hline 1.45 & 4239 & Miscellaneous durable goods merchant wholesalers \\
\hline 1.44 & 7222 & Limited-service eating places \\
\hline 1.44 & 4241 & Paper and paper product merchant wholesalers \\
\hline 1.44 & 3273 & Cement and concrete product manufacturing \\
\hline 1.43 & 4413 & Automotive parts, accessories, and tire stores \\
\hline 1.43 & 48 & Transportation and warehousing \\
\hline 1.42 & 4885 & Freight transportation arrangement \\
\hline 1.41 & 8111 & Automotive repair and maintenance \\
\hline 1.41 & 32 & Manufacturing \\
\hline
\end{tabular}




$\begin{array}{lcl}1.41 & 6214 & \text { Outpatient care centers } \\ 1.40 & 4236 & \text { Electrical and electronic goods merchant wholesalers } \\ 1.37 & 3391 & \text { Medical equipment and supplies manufacturing } \\ 1.37 & 4812 & \text { Nonscheduled air transportation } \\ 1.36 & 5611 & \text { Office administrative services } \\ 1.36 & 334 & \text { Computer and electronic product manufacturing } \\ 1.36 & 42 & \text { Wholesale trade } \\ 1.36 & 324 & \text { Petroleum and coal products manufacturing } \\ 1.36 & 3241 & \text { Petroleum and coal products manufacturing } \\ 1.35 & 4453 & \text { Beer, wine, and liquor stores } \\ 1.35 & 3371 & \text { Household and institutional furniture mfg. } \\ 1.34 & 4922 & \text { Local messengers and local delivery } \\ 1.34 & 811 & \text { Repair and maintenance } \\ 1.33 & 7212 & \text { RV (recreational vehicle) parks and recreational camps } \\ 1.32 & 3352 & \text { Household appliance manufacturing } \\ 1.31 & 6212 & \text { Offices of dentists } \\ 1.31 & 4881 & \text { Support activities for air transportation } \\ 1.31 & 3133 & \text { Textile and fabric finishing and fabric coating mills } \\ 1.31 & 3115 & \text { Dairy product manufacturing } \\ 1.31 & 4246 & \text { Chemical and allied products merchant wholesalers } \\ 1.30 & 3339 & \text { Other general purpose machinery manufacturing } \\ 1.30 & 8113 & \text { Commercial machinery repair and maintenance } \\ 1.29 & 5324 & \text { Machinery and equipment rental and leasing } \\ 1.29 & 339 & \text { Miscellaneous manufacturing } \\ 1.28 & 2362 & \text { Nonresidential building construction } \\ 1.27 & 3333 & \text { Commercial and service industry machinery manufacturing } \\ 1.27 & 3271 & \text { Clay product and refractory manufacturing } \\ 1.27 & 321 & \text { Wood product manufacturing } \\ 1.27 & 2389 & \text { Other specialty trade contractors } \\ 1.27 & 327 & \text { Nonmetallic mineral product manufacturing } \\ 1.27 & 3113 & \text { Sugar and confectionery product manufacturing } \\ 1.26 & 4482 & \text { Shoe stores } \\ 1.26 & 6233 & \text { Community care facilities for the elderly } \\ 1.26 & 424 & \text { Merchant wholesalers, nondurable goods } \\ 1.26 & 3119 & \text { Other food manufacturing } \\ 1.25 & 8112 & \text { Electronic and precision equipment repair and maintenance } \\ 1.25 & 2371 & \text { Utility system construction } \\ 1.25 & 492 & \text { Couriers and messengers }\end{array}$

San Diego County

$\begin{array}{rcl} & 2007 \text { NAICS } & \\ \text { STEMP } & \text { code } & \text { Description } \\ 9.02 & 3366 & \text { Ship and boat building }\end{array}$


Engine, turbine, and power transmission equipment

$5.62 \quad 3336 \quad$ manufacturing

$3.64 \quad 4872$

Scenic and sightseeing transportation, water

$3.57 \quad 4862$

$2.88 \quad 712$

Pipeline transportation of natural gas

$2.88 \quad 7121$

$2.77 \quad 487$

$2.18 \quad 3341$

$2.16 \quad 6114$

$2.08 \quad 1141$

$2.00 \quad 3399$

$1.99 \quad 5417$

$1.99 \quad 5174$

$1.95 \quad 1152$

$1.91 \quad 7224$

$1.85 \quad 7132$

$1.83 \quad 7211$

$1.81 \quad 8112$

$1.81 \quad 721$

$1.78 \quad 4542$

$1.76 \quad 8132$

$1.68 \quad 5418$

$1.64 \quad 336$

$1.63 \quad 7131$

$1.63 \quad 4851$

$1.62 \quad 5313$

$1.60 \quad 114$

$1.57 \quad 5612$

$1.55 \quad 5323$

$1.54 \quad 5419$

$1.52 \quad 6115$

$1.49 \quad 4236$

$1.47 \quad 5231$

$1.45 \quad 333$

$1.44 \quad 6214$

$1.44 \quad 4855$

$1.41 \quad 339$

$1.41 \quad 3359$

$1.39 \quad 533$

$1.39 \quad 5331$

$1.37 \quad 531$

$1.35 \quad 5611$

$1.35 \quad 4412$

$1.34 \quad 2372$

Museums, historical sites, and similar institutions

Museums, historical sites, and similar institutions

Scenic and sightseeing transportation

Computer and peripheral equipment manufacturing

Business schools and computer and management training

Fishing

Other miscellaneous manufacturing

Scientific research and development services

Satellite telecommunications

Support activities for animal production

Drinking places (alcoholic beverages)

Gambling industries

Traveler accommodation

Electronic and precision equipment repair and maintenance

Accommodation

Vending machine operators

Grantmaking and giving services

Advertising, public relations, and related services

Transportation equipment manufacturing

Amusement parks and arcades

Urban transit systems

Activities related to real estate

Fishing, hunting and trapping

Facilities support services

General rental centers

Other professional, scientific, and technical services

Technical and trade schools

Electrical and electronic goods merchant wholesalers

Securities and commodity contracts intermediation and

brokerage

Machinery manufacturing

Outpatient care centers

Charter bus industry

Miscellaneous manufacturing

Other electrical equipment and component manufacturing

Lessors of nonfinancial intangible assets

Lessors of nonfinancial intangible assets

Real estate

Office administrative services

Other motor vehicle dealers

Land subdivision 


$\begin{array}{lcl}1.32 & 7112 & \text { Spectator sports } \\ 1.32 & 2373 & \text { Highway, street, and bridge construction } \\ 1.32 & 6117 & \text { Educational support services } \\ 1.31 & 713 & \text { Amusement, gambling, and recreation industries } \\ 1.31 & 5413 & \text { Architectural, engineering, and related services } \\ 1.31 & 8121 & \text { Personal care services } \\ 1.30 & 3343 & \text { Audio and video equipment manufacturing } \\ 1.30 & 6233 & \text { Community care facilities for the elderly } \\ 1.30 & 3254 & \text { Pharmaceutical and medicine manufacturing } \\ 1.30 & 2389 & \text { Other specialty trade contractors } \\ 1.30 & 3364 & \text { Aerospace product and parts manufacturing } \\ 1.28 & 5614 & \text { Business support services } \\ 1.27 & 71 & \text { Arts, entertainment, and recreation } \\ 1.25 & 53 & \text { Real estate and rental and leasing } \\ 1.25 & 7111 & \text { Performing arts companies } \\ 1.25 & 2362 & \text { Nonresidential building construction }\end{array}$

2007 NAICS

\begin{tabular}{|c|c|c|}
\hline USEMP & code & Description \\
\hline 5.86 & 3366 & Ship and boat building \\
\hline 5.57 & 4872 & Scenic and sightseeing transportation, water \\
\hline 4.13 & 3336 & $\begin{array}{l}\text { Engine, turbine, and power transmission equipment } \\
\text { manufacturing }\end{array}$ \\
\hline 4.01 & 7132 & Gambling industries \\
\hline 3.74 & 7131 & Amusement parks and arcades \\
\hline 3.67 & 3342 & Communications equipment manufacturing \\
\hline 3.66 & 5417 & Scientific research and development services \\
\hline 3.32 & 3341 & Computer and peripheral equipment manufacturing \\
\hline 3.30 & 4851 & Urban transit systems \\
\hline 3.12 & 4236 & Electrical and electronic goods merchant wholesalers \\
\hline 3.00 & 487 & Scenic and sightseeing transportation \\
\hline 2.87 & 712 & Museums, historical sites, and similar institutions \\
\hline 2.87 & 7121 & Museums, historical sites, and similar institutions \\
\hline 2.62 & 5418 & Advertising, public relations, and related services \\
\hline 2.61 & 8112 & Electronic and precision equipment repair and maintenance \\
\hline 2.45 & 5112 & Software publishers \\
\hline 2.30 & 3343 & Audio and video equipment manufacturing \\
\hline 2.26 & 5313 & Activities related to real estate \\
\hline 2.23 & 3169 & Other leather and allied product manufacturing \\
\hline 2.20 & 3399 & Other miscellaneous manufacturing \\
\hline 2.19 & 6114 & Business schools and computer and management training \\
\hline 2.18 & 8132 & Grantmaking and giving services \\
\hline 2.15 & 2372 & Land subdivision \\
\hline 2.08 & 2212 & Natural gas distribution \\
\hline
\end{tabular}




\begin{tabular}{|c|c|c|}
\hline 2.02 & 3364 & Aerospace product and parts manufacturing \\
\hline 1.99 & 4884 & Support activities for road transportation \\
\hline 1.97 & 7211 & Traveler accommodation \\
\hline 1.95 & 721 & Accommodation \\
\hline 1.93 & 3254 & Pharmaceutical and medicine manufacturing \\
\hline 1.89 & 6115 & Technical and trade schools \\
\hline 1.87 & 339 & Miscellaneous manufacturing \\
\hline 1.87 & 334 & Computer and electronic product manufacturing \\
\hline 1.79 & 5414 & Specialized design services \\
\hline 1.76 & 531 & Real estate \\
\hline 1.76 & 1152 & Support activities for animal production \\
\hline 1.70 & 2383 & Building finishing contractors \\
\hline 1.68 & 713 & Amusement, gambling, and recreation industries \\
\hline 1.66 & 5174 & Satellite telecommunications \\
\hline 1.65 & 71 & Arts, entertainment, and recreation \\
\hline 1.63 & 7111 & Performing arts companies \\
\hline 1.59 & 533 & Lessors of nonfinancial intangible assets \\
\hline 1.59 & 5331 & Lessors of nonfinancial intangible assets \\
\hline 1.57 & 8129 & Other personal services \\
\hline 1.56 & 6117 & Educational support services \\
\hline 1.56 & 7224 & Drinking places (alcoholic beverages) \\
\hline 1.55 & 54 & Professional, scientific, and technical services \\
\hline 1.55 & 541 & Professional, scientific, and technical services \\
\hline 1.54 & 4521 & Department stores \\
\hline 1.54 & 5419 & Other professional, scientific, and technical services \\
\hline 1.53 & 53 & Real estate and rental and leasing \\
\hline 1.51 & 3391 & Medical equipment and supplies manufacturing \\
\hline 1.48 & 5611 & Office administrative services \\
\hline 1.47 & 511 & Publishing industries (except Internet) \\
\hline 1.47 & 3344 & Semiconductor and other electronic component manufacturing \\
\hline 1.46 & 5413 & Architectural, engineering, and related services \\
\hline 1.43 & 3345 & Electronic instrument manufacturing \\
\hline 1.43 & 4855 & Charter bus industry \\
\hline 1.41 & 5311 & Lessors of real estate \\
\hline 1.38 & 7212 & RV (recreational vehicle) parks and recreational camps \\
\hline 1.38 & 2361 & Residential building construction \\
\hline 1.38 & 7112 & Spectator sports \\
\hline 1.37 & 6214 & Outpatient care centers \\
\hline 1.36 & 5312 & Offices of real estate agents and brokers \\
\hline 1.34 & 4481 & Clothing stores \\
\hline 1.32 & 4422 & Home furnishings stores \\
\hline 1.31 & 4249 & Miscellaneous nondurable goods merchant wholesalers \\
\hline 1.30 & 236 & Construction of buildings \\
\hline 1.29 & 5222 & Nondepository credit intermediation \\
\hline 1.29 & 5617 & Services to buildings and dwellings \\
\hline
\end{tabular}




$\begin{array}{lcl}1.28 & 448 & \text { Clothing and clothing accessories stores } \\ 1.27 & 5324 & \text { Machinery and equipment rental and leasing } \\ 1.27 & 72 & \text { Accommodation and food services } \\ 1.26 & 3359 & \text { Other electrical equipment and component manufacturing } \\ 1.26 & 5416 & \text { Management, scientific, and technical consulting services } \\ 1.25 & 5415 & \text { Computer systems design and related services }\end{array}$

2007 NAICS

$\begin{array}{rcl}\text { STEST } & \text { code } & \text { Description } \\ 3.13 & 4872 & \text { Scenic and sightseeing transportation, water } \\ 2.98 & 3366 & \text { Ship and boat building } \\ 2.81 & 4879 & \text { Scenic and sightseeing transportation, other } \\ 2.52 & 1141 & \text { Fishing } \\ 2.51 & 487 & \text { Scenic and sightseeing transportation } \\ 2.32 & 5417 & \text { Scientific research and development services } \\ 2.21 & 3254 & \text { Pharmaceutical and medicine manufacturing } \\ 2.18 & 114 & \text { Fishing, hunting and trapping } \\ 1.81 & 4832 & \text { Inland water transportation } \\ 1.74 & 1152 & \text { Support activities for animal production } \\ 1.73 & 6114 & \text { Business schools and computer and management training } \\ & & \text { Engine, turbine, and power transmission equipment } \\ 1.64 & 3336 & \text { manufacturing } \\ 1.62 & 2212 & \text { Natural gas distribution } \\ 1.61 & 1132 & \text { Forest nurseries and gathering of forest products } \\ 1.59 & 3169 & \text { Other leather and allied product manufacturing } \\ 1.55 & 3161 & \text { Leather and hide tanning and finishing } \\ 1.54 & 5612 & \text { Facilities support services } \\ 1.53 & 3369 & \text { Other transportation equipment manufacturing } \\ 1.53 & 5312 & \text { Offices of real estate agents and brokers } \\ 1.49 & 3342 & \text { Communications equipment manufacturing } \\ 1.48 & 483 & \text { Water transportation } \\ 1.47 & 2372 & \text { Land subdivision } \\ 1.46 & 3345 & \text { Electronic instrument manufacturing } \\ 1.45 & 6113 & \text { Colleges, universities, and professional schools } \\ 1.44 & 3352 & \text { Household appliance manufacturing } \\ 1.41 & 3343 & \text { Audio and video equipment manufacturing } \\ 1.38 & 6222 & \text { Psychiatric and substance abuse hospitals } \\ 1.36 & 4831 & \text { Deep sea, coastal, and great lakes water transportation } \\ 1.35 & 4412 & \text { Other motor vehicle dealers } \\ 1.34 & 5416 & \text { Management, scientific, and technical consulting services } \\ 1.34 & 5313 & \text { Activities related to real estate } \\ 1.28 & 531 & \text { Real estate } \\ 1.28 & 4233 & \text { Lumber and other construction materials merchant wholesalers } \\ 1.28 & 5323 & \text { General rental centers } \\ & & \end{array}$




$\begin{array}{lcl}1.27 & 316 & \text { Leather and allied product manufacturing } \\ 1.26 & 3399 & \text { Other miscellaneous manufacturing } \\ 1.25 & 5239 & \text { Other financial investment activities } \\ 1.25 & 5413 & \text { Architectural, engineering, and related services } \\ 1.25 & 5419 & \text { Other professional, scientific, and technical services }\end{array}$

\section{NAICS}

\begin{tabular}{|c|c|c|}
\hline USEST & code & Description \\
\hline 4.00 & 5417 & Scientific research and development services \\
\hline 3.42 & 4879 & Scenic and sightseeing transportation, other \\
\hline 3.18 & 3254 & Pharmaceutical and medicine manufacturing \\
\hline 3.08 & 3369 & Other transportation equipment manufacturing \\
\hline 2.99 & 3343 & Audio and video equipment manufacturing \\
\hline 2.88 & 3342 & Communications equipment manufacturing \\
\hline 2.70 & 3341 & Computer and peripheral equipment manufacturing \\
\hline 2.62 & 4872 & Scenic and sightseeing transportation, water \\
\hline 2.51 & 334 & Computer and electronic product manufacturing \\
\hline 2.47 & 3344 & Semiconductor and other electronic component manufacturing \\
\hline 2.40 & 3345 & Electronic instrument manufacturing \\
\hline 2.25 & 487 & Scenic and sightseeing transportation \\
\hline 2.09 & 3346 & Manufacturing and reproducing magnetic and optical media \\
\hline 1.97 & 3366 & Ship and boat building \\
\hline 1.89 & 1152 & Support activities for animal production \\
\hline 1.88 & 3169 & Other leather and allied product manufacturing \\
\hline 1.78 & 5313 & Activities related to real estate \\
\hline 1.78 & 6113 & Colleges, universities, and professional schools \\
\hline 1.77 & 6114 & Business schools and computer and management training \\
\hline 1.75 & 5112 & Software publishers \\
\hline 1.75 & 5416 & Management, scientific, and technical consulting services \\
\hline 1.70 & 4541 & Electronic shopping and mail-order houses \\
\hline 1.66 & 3161 & Leather and hide tanning and finishing \\
\hline 1.66 & 5312 & Offices of real estate agents and brokers \\
\hline 1.58 & 3359 & Other electrical equipment and component manufacturing \\
\hline 1.57 & 4236 & Electrical and electronic goods merchant wholesalers \\
\hline 1.56 & 5611 & Office administrative services \\
\hline 1.55 & 316 & Leather and allied product manufacturing \\
\hline 1.55 & 5179 & Other telecommunications \\
\hline 1.54 & 3399 & Other miscellaneous manufacturing \\
\hline 1.52 & 531 & Real estate \\
\hline 1.50 & 525 & Funds, trusts, and other financial vehicles \\
\hline 1.50 & 5259 & Other investment pools and funds \\
\hline 1.50 & 5223 & Activities related to credit intermediation \\
\hline 1.49 & 5239 & Other financial investment activities \\
\hline 1.45 & 4851 & Urban transit systems \\
\hline
\end{tabular}




$\begin{array}{lcl}1.45 & 2372 & \text { Land subdivision } \\ 1.43 & 5415 & \text { Computer systems design and related services } \\ 1.43 & 5413 & \text { Architectural, engineering, and related services } \\ 1.41 & 53 & \text { Real estate and rental and leasing } \\ 1.41 & 339 & \text { Miscellaneous manufacturing } \\ 1.41 & 8129 & \text { Other personal services } \\ 1.41 & 6117 & \text { Educational support services } \\ 1.41 & 4242 & \text { Drugs and druggists' sundries merchant wholesalers } \\ 1.40 & 3352 & \text { Household appliance manufacturing } \\ 1.40 & 3351 & \text { Electric lighting equipment manufacturing } \\ 1.39 & 3333 & \text { Commercial and service industry machinery manufacturing } \\ 1.39 & 5414 & \text { Specialized design services } \\ 1.39 & 54 & \text { Professional, scientific, and technical services } \\ 1.39 & 541 & \text { Professional, scientific, and technical services } \\ 1.39 & 6115 & \text { Technical and trade schools } \\ 1.36 & 4249 & \text { Miscellaneous nondurable goods merchant wholesalers } \\ 1.34 & 3379 & \text { Other furniture related product manufacturing } \\ & & \text { Engine, turbine, and power transmission equipment } \\ 1.33 & 3336 & \text { manufacturing } \\ 1.32 & 518 & \text { Data processing, hosting and related services } \\ 1.32 & 5182 & \text { Data processing, hosting, and related services } \\ 1.31 & 4855 & \text { Charter bus industry } \\ 1.30 & 3364 & \text { Aerospace product and parts manufacturing } \\ 1.29 & 6212 & \text { Offices of dentists } \\ 1.28 & 511 & \text { Publishing industries (except Internet) } \\ 1.25 & 6233 & \text { Community care facilities for the elderly } \\ 1.25 & 523 & \text { Securities, commodity contracts, investments } \\ & & \end{array}$

\section{Table A-3: Application Code}

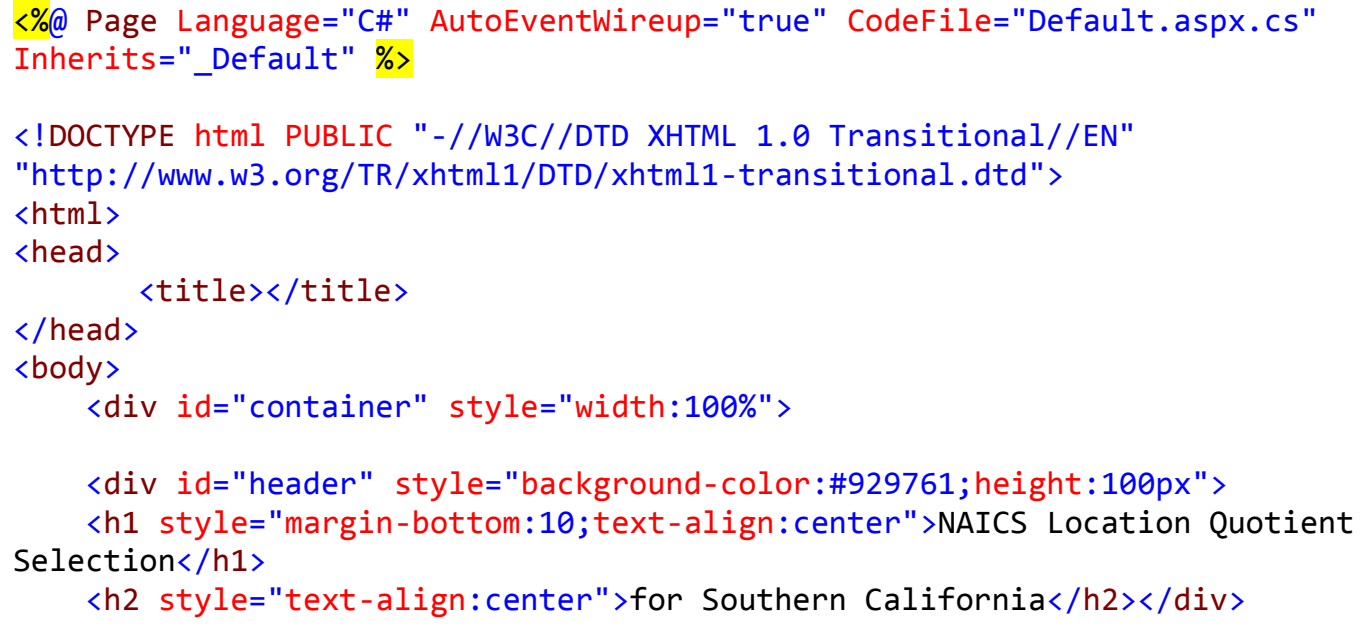




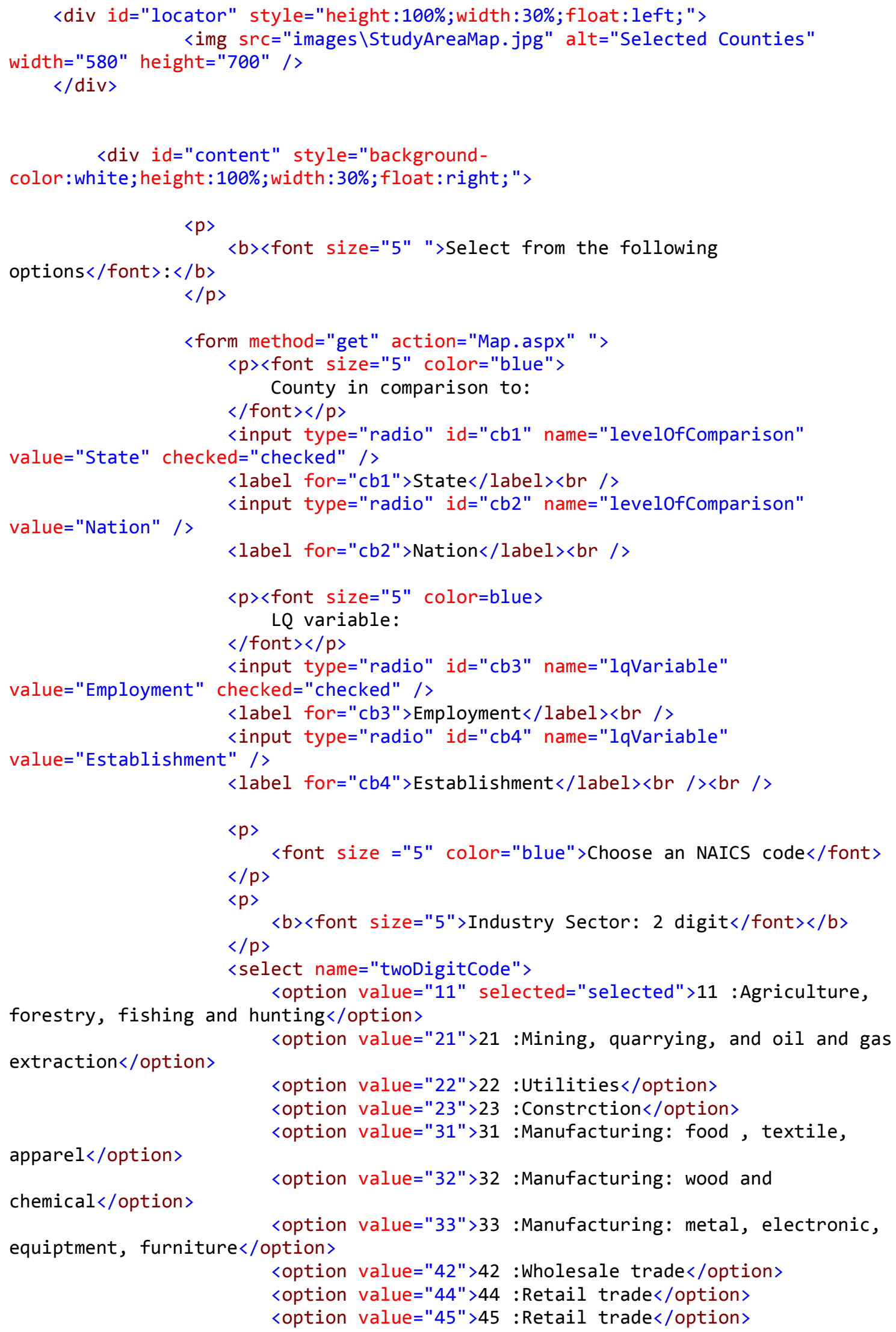




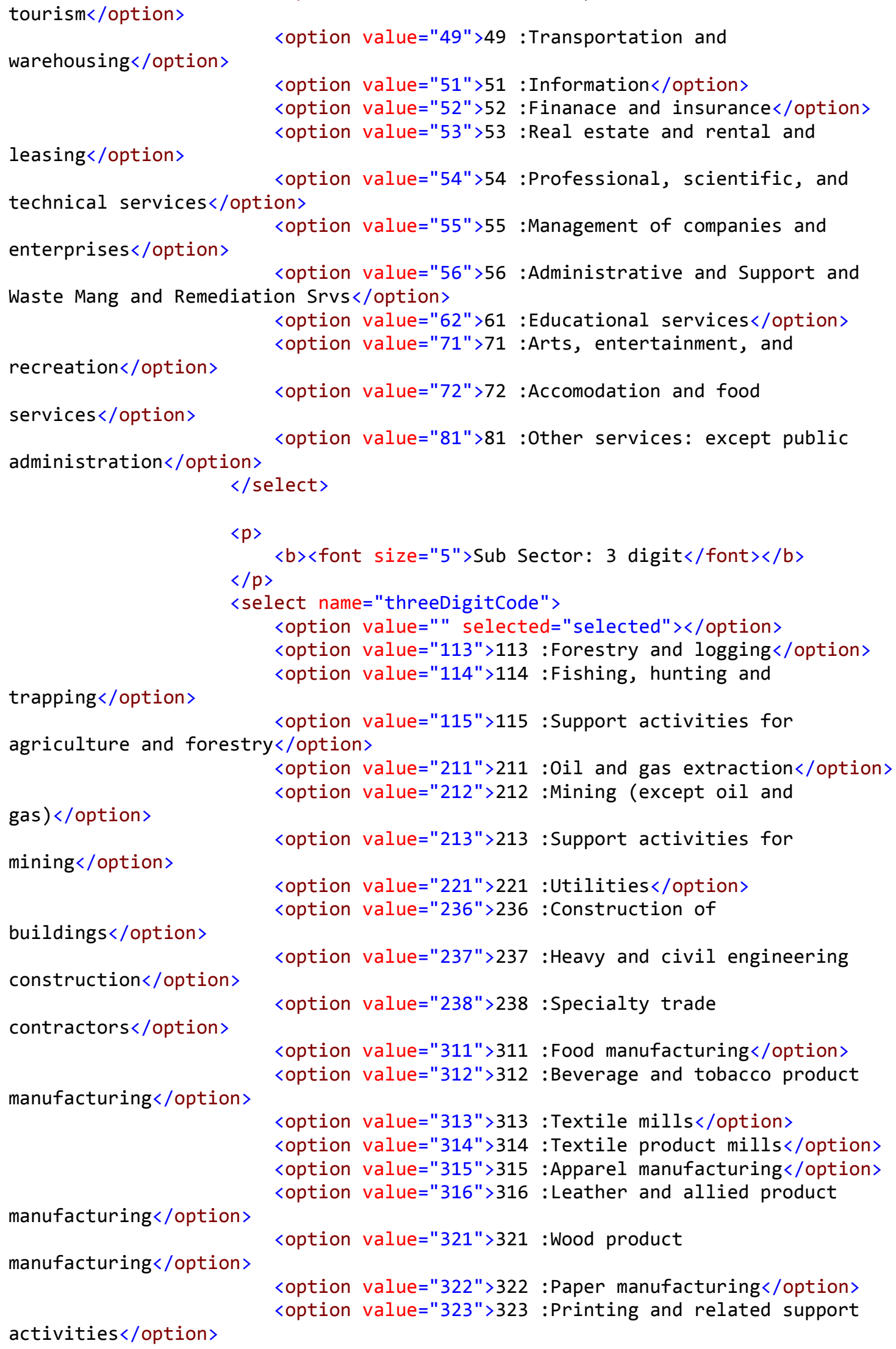




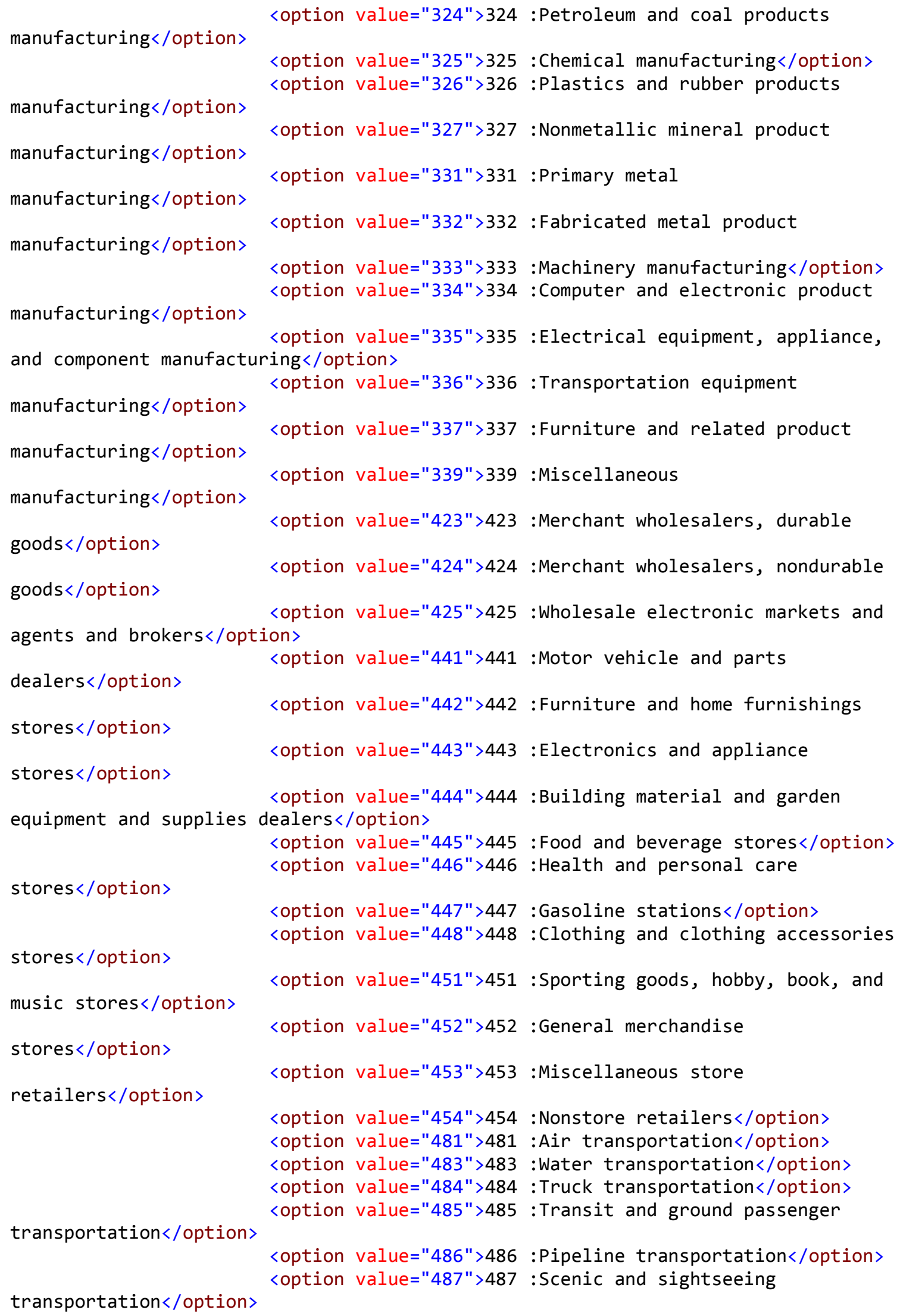




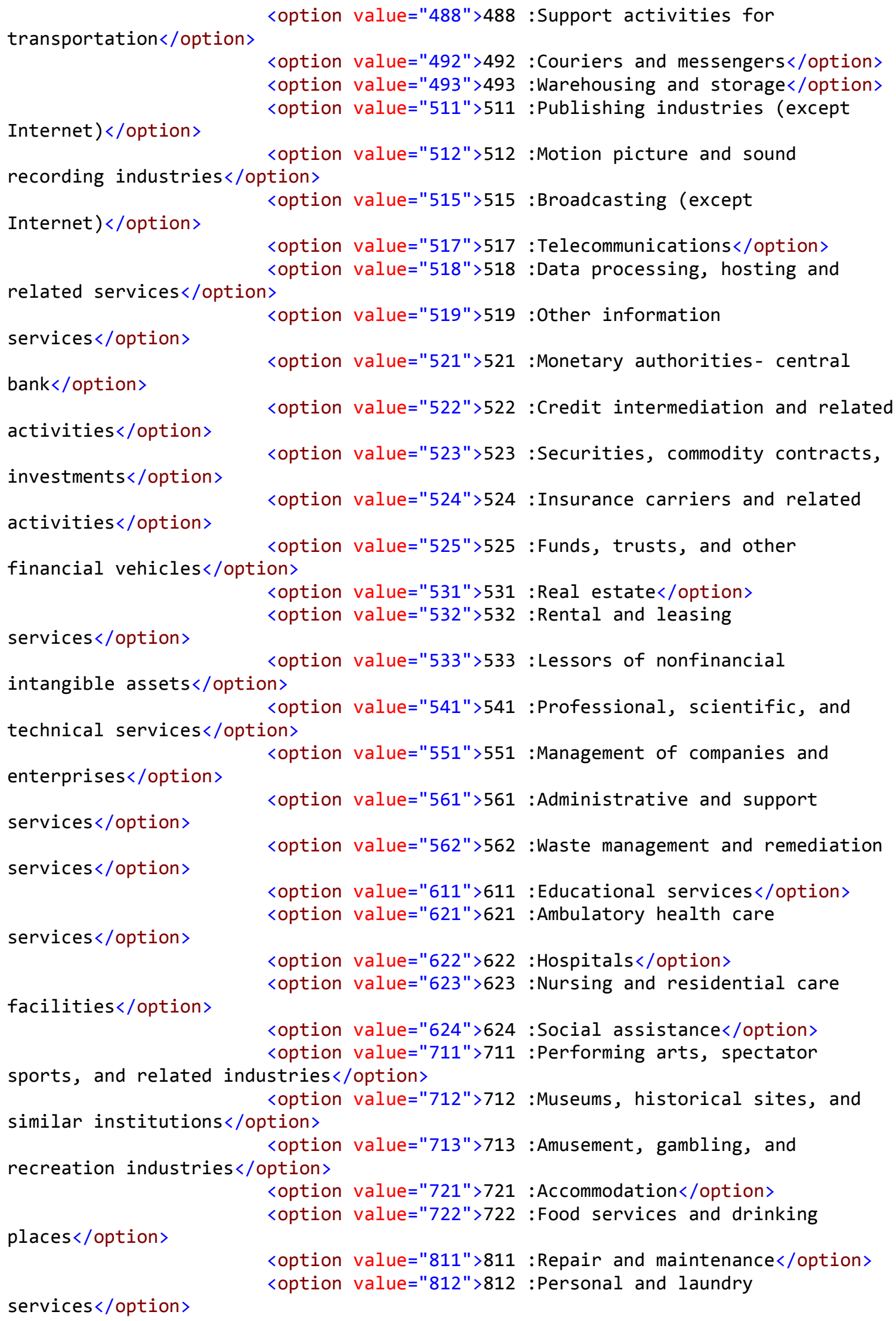


<option value="813">813 :Religious, Grantmaking, Civic, Professional, and Similar Orgs</option $>$

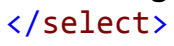




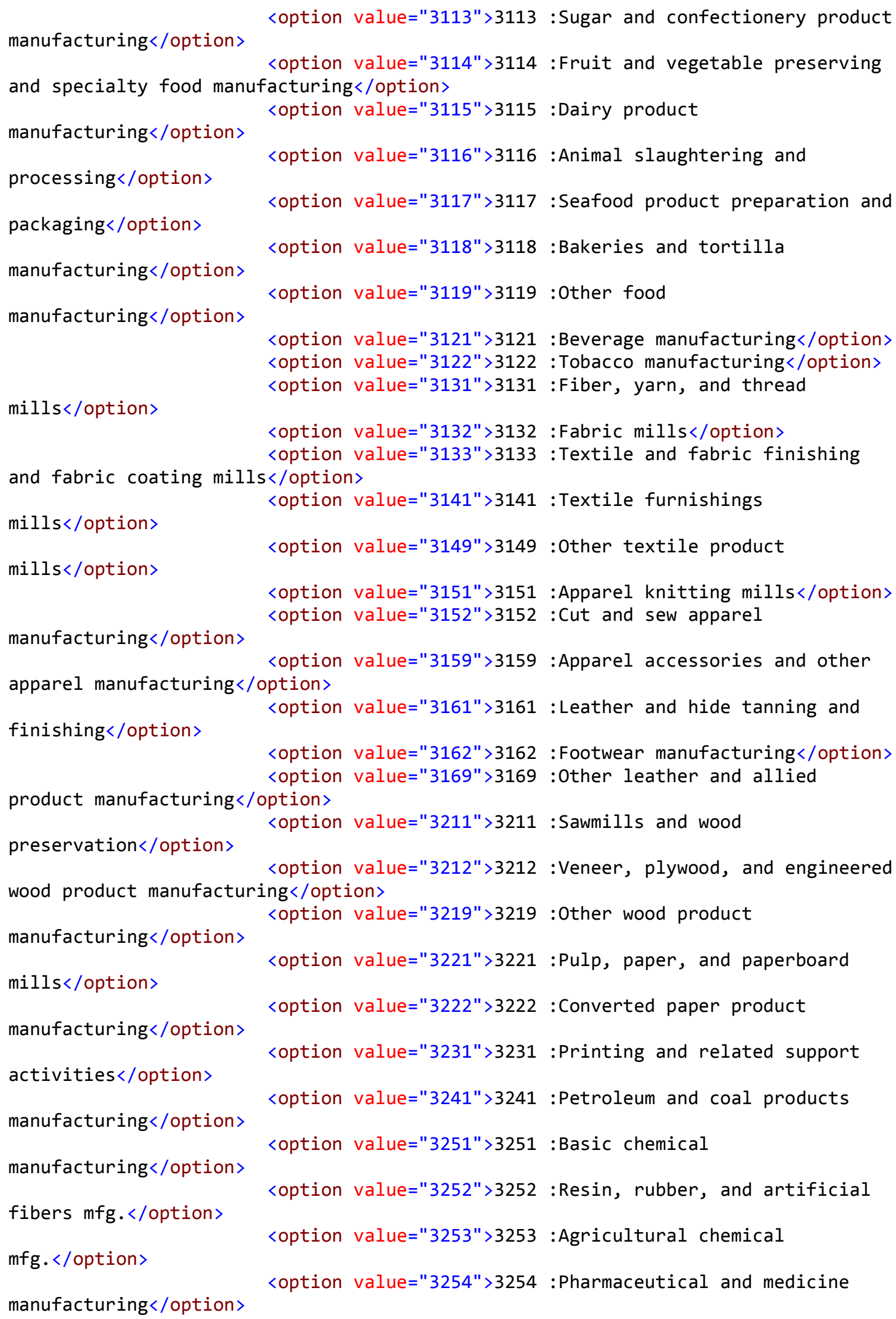




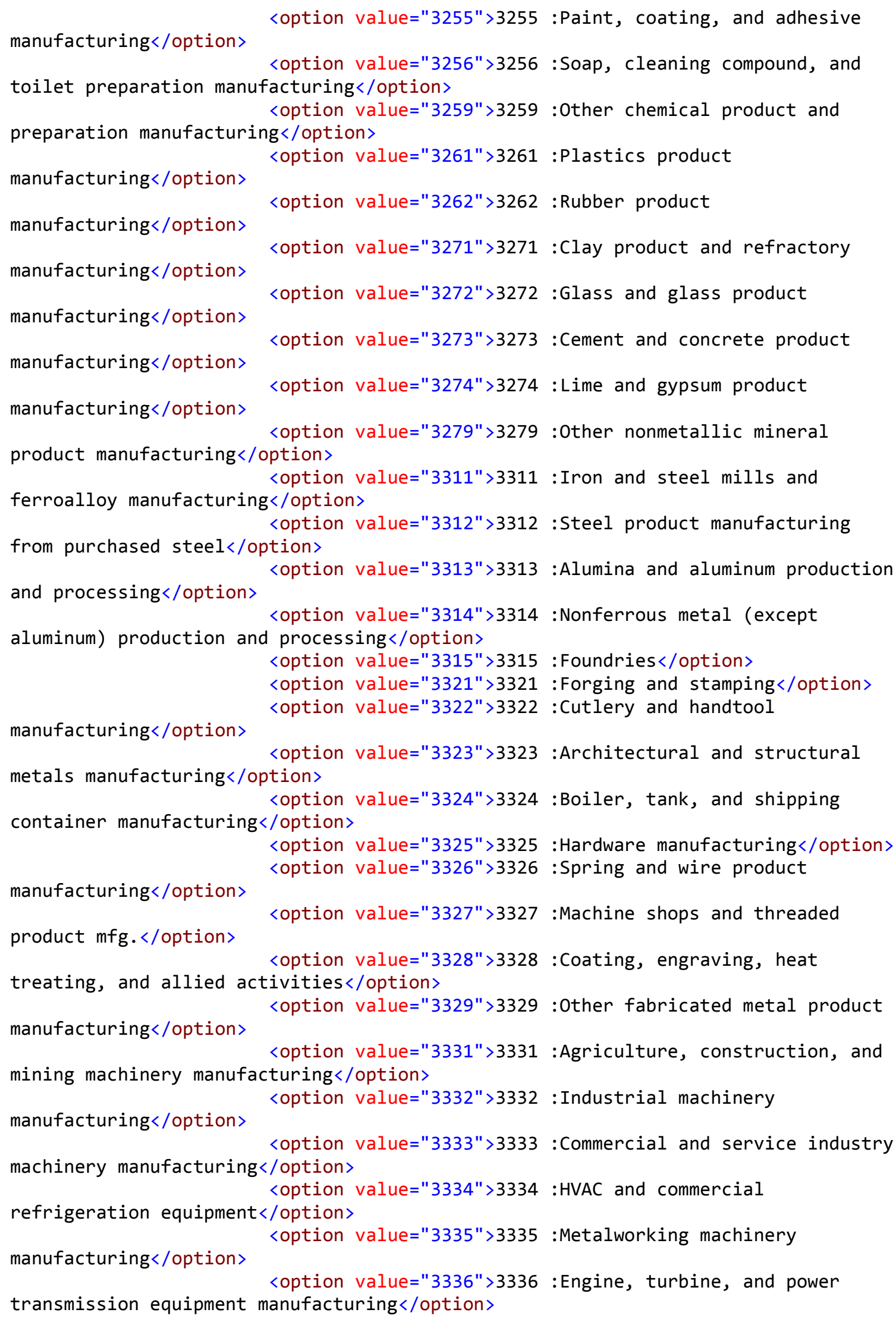




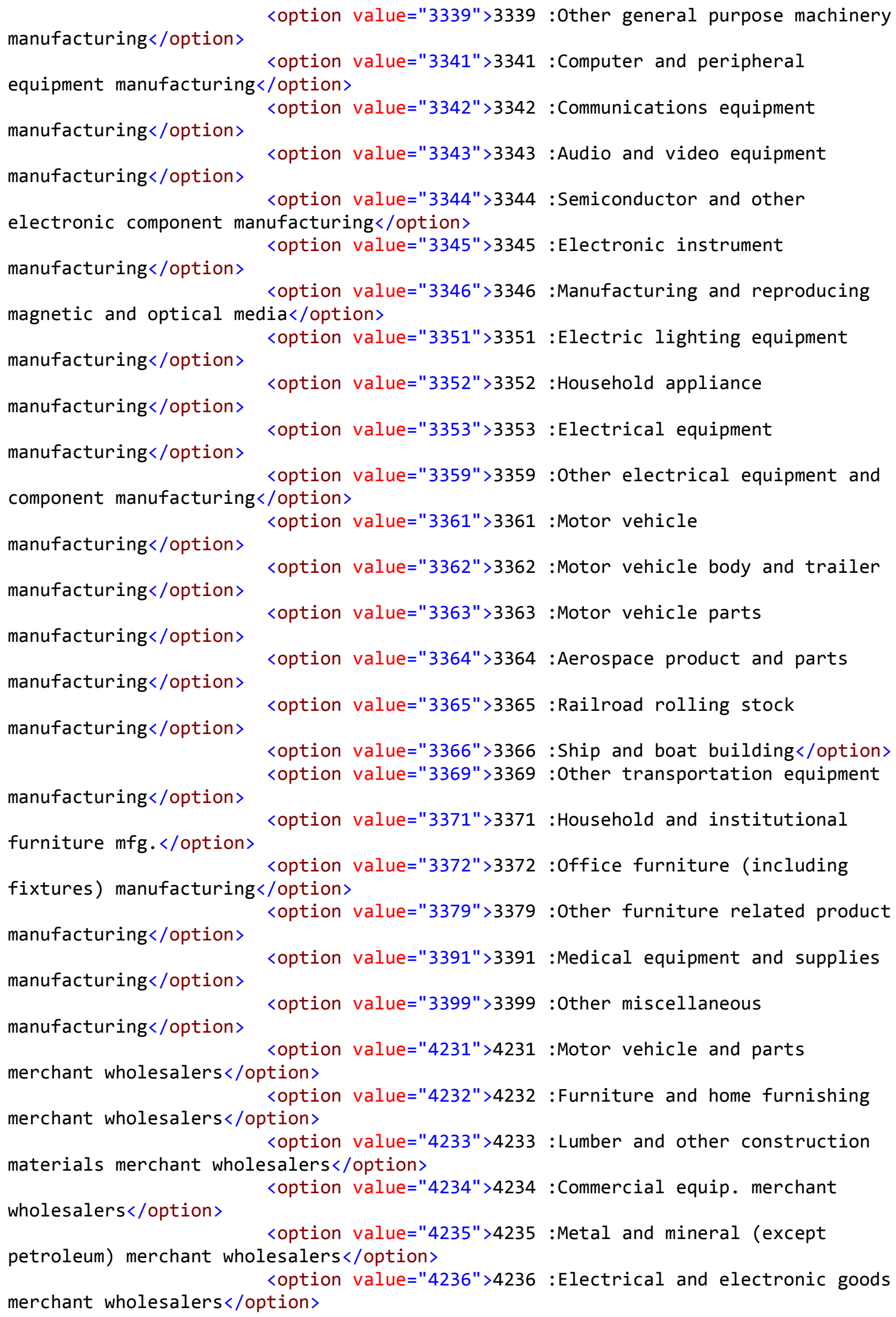


wholesalers</option>

<option value="4237">4237 :Hardware and plumbing merchant supplies merchant wholesalers</option> merchant wholesalers</option> <option value="4239">4239 :Miscellaneous durable goods merchant wholesalers</option> <option value="4241">4241 :Paper and paper product merchant wholesalers</option> <option value="4242">4242 :Drugs and druggists' sundries <option value="4243">4243 :Apparel, piece goods, and notions merchant wholesalers</option> <option value="4244">4244 :Grocery and related product merchant wholesalers</option> <option value="4245">4245 :Farm product raw material merchant wholesalers</option> <option value="4246">4246 :Chemical and allied products products merchant wholesalers</option> <option value="4248">4248 :Beer, wine, and distilled alcoholic beverage merchant wholesalers</option> <option value="4249">4249 :Miscellaneous nondurable goods merchant wholesalers</option> <option value="4251">4251 :Wholesale electronic markets and agents and brokers</option> <option value="4411">4411 :Automobile dealers</option> <option value="4412">4412 :Other motor vehicle

dealers</option> and tire stores</option $>$ <option value="4413">4413 :Automotive parts, accessories, <option value="4421">4421 :Furniture stores</option> <option value="4422">4422 :Home furnishings

stores</option> <option value="4431">4431 :Electronics and appliance stores</option> dealers</option> supplies stores</option > <option value="4441">4441 :Building material and supplies <option value="4442">4442 :Lawn and garden equipment and <option value="4451">4451 :Grocery stores</option> <option value="4452">4452 :Specialty food stores</option> stores</option> <option value="4453">4453 :Beer, wine, and liquor

stores</option> <option value="4461">4461 : Health and personal care <option value="4471">4471 :Gasoline stations</option> <option value="4481">4481 :Clothing stores</option> <option value="4482">4482 :Shoe stores</option> <option value="4483">4483 : Jewelry, luggage, and leather

goods stores</option> <option value="4511">4511 :Sporting goods, hobby, and musical instrument stores</option> <option value="4512">4512 :Book, periodical, and music stores</option> <option value="4521">4521 :Department stores</option> <option value="4529">4529 :Other general merchandise

stores</option> 
<option value="4531">4531 :Florists</option>

<option value="4532">4532 :Office supplies, stationery,

and gift stores</option>

<option value="4533">4533 :Used merchandise

stores</option>

<option value="4539">4539 :Other miscellaneous store

retailers</option>

order houses</option>

<option value="4541">4541 :Electronic shopping and mail-

operators</option>

<option value="4542">4542 :Vending machine

establishments</option>

<option value="4543">4543 :Direct selling

<option value="4811">4811 :Scheduled air

transportation</option>

<option value="4812">4812 :Nonscheduled air

transportation</option>

<option value="4831">4831 :Deep sea, coastal, and great

lakes water transportation</option>

<option value="4832">4832 : Inland water

transportation</option>

trucking</option>

<option value="4841">4841 :General freight

trucking</option>

<option value="4842">4842 :Specialized freight

<option value="4851">4851 :Urban transit systems</option>

<option value="4852">4852 :Interurban and rural bus

transportation</option>

<option value="4853">4853 :Taxi and limousine

service</option>

transportation</option>

<option value="4854">4854 :School and employee bus

<option value="4855">4855 :Charter bus industry</option>

<option value="4859">4859 :Other transit and ground

passenger transportation</option>

<option value="4861">4861 :Pipeline transportation of

crude oil</option>

natural gas</option>

transportation</option>

<option value="4862">4862 :Pipeline transportation of

transportation, land</option>

<option value="4869">4869 :Other pipeline

<option value="4871">4871 :Scenic and sightseeing

transportation, water</option $>$

<option value="4872">4872 :Scenic and sightseeing

transportation, other</option $>$

<option value="4881">4881 :Support activities for air

transportation</option $>$

<option value="4882">4882 :Support activities for rail

transportation</option $>$

transportation</option>

<option value="4883">4883 :Support activities for water

transportation</option>

<option value="4884">4884 :Support activities for road

arrangement</option>

<option value="4885">4885 :Freight transportation 


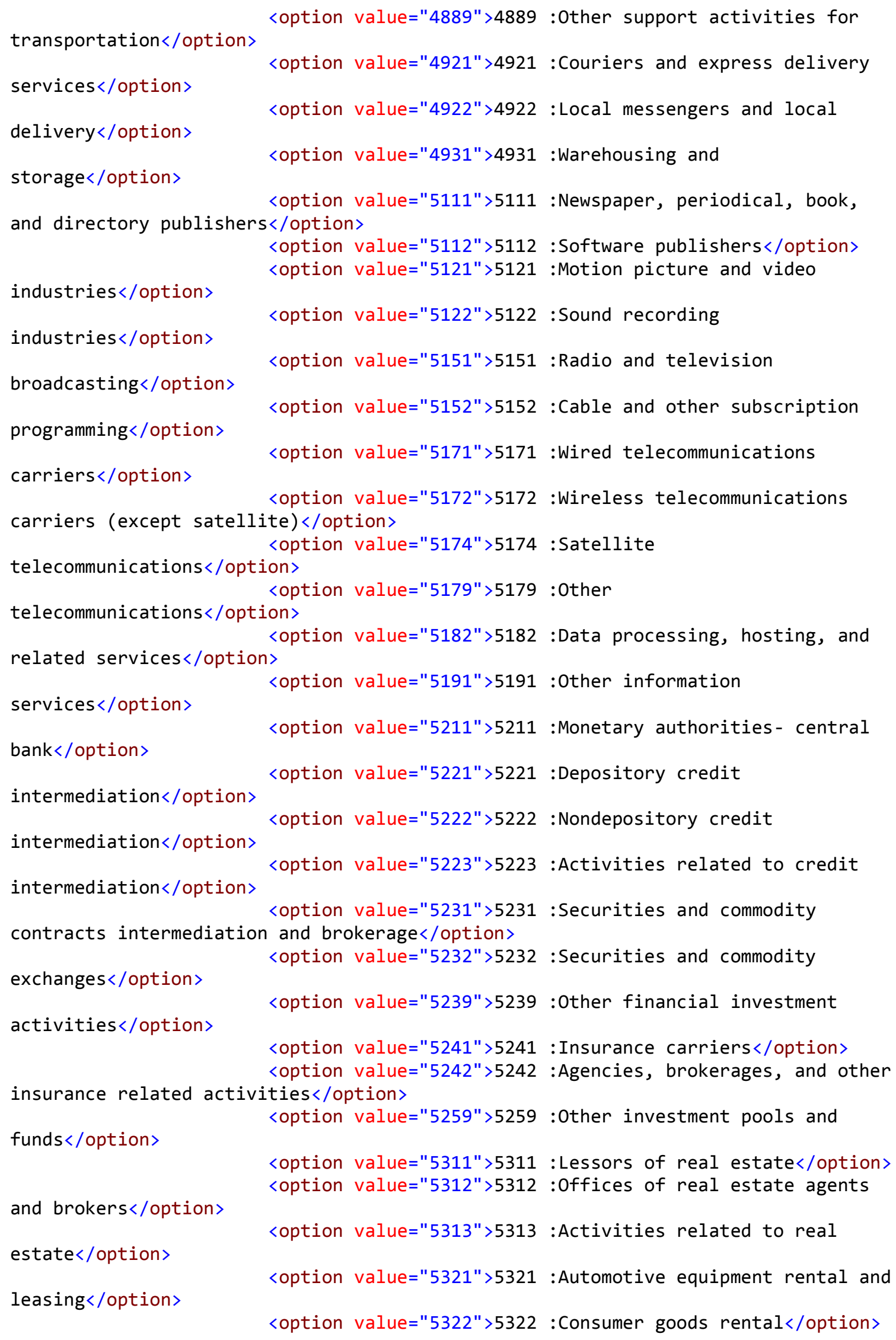


<option value="5323">5323:General rental centers</option> <option value="5324">5324 :Machinery and equipment rental

and leasing</option>

intangible assets</option>

<option value=" $5331 ">5331$ :Lessors of nonfinancial

<option value="5411">5411 :Legal services</option>

<option value="5412">5412 :Accounting, tax preparation,

bookkeeping, and payroll services</option>

related services</option>

<option value="5413">5413 :Architectural, engineering, and

services</option>

related services</option $>$

<option value="5414">5414 :Specialized design

<option value="5415">5415 :Computer systems design and

<option value="5416">5416 :Management, scientific, and

technical consulting services</option>

development services</option>

<option value="5417">5417 :Scientific research and

and related services</option>

<option value="5418">5418 :Advertising, public relations,

and technical services</option>

<option value="5419">5419 :Other professional, scientific,

enterprises</option>

services</option>

<option value="5511">5511 :Management of companies and

services</option>

<option value="5611">5611 :Office administrative

<option value="5612">5612 :Facilities support

<option value="5613">5613 :Employment services</option>

services</option>

<option value $=" 5614 ">5614$ : Business support

reservation services</option>

<option value="5615">5615 :Travel arrangement and

services</option>

<option value="5616">5616 : Investigation and security

dwellings</option>

<option value="5617">5617 :Services to buildings and

<option value=" $5619 ">5619$ :Other support services</option> <option value="5621">5621 :Waste collection</option>

<option value="5622">5622 :Waste treatment and

disposal</option>

<option value="5629">5629 :Remediation and other waste

management services</option>

schools</option>

<option value="6111">6111 :Elementary and secondary

<option value="6112">6112 :Junior colleges</option>

<option value="6113">6113 :Colleges, universities, and

professional schools</option>

<option value="6114">6114 :Business schools and computer

and management training</option $>$

<option value="6115">6115 :Technical and trade

schools</option>

instruction</option>

services</option>

<option value="6116">6116 :Other schools and

<option value="6117">6117 :Educational support

<option value="6211">6211 :Offices of physicians</option> <option value="6212">6212 :Offices of dentists</option> 


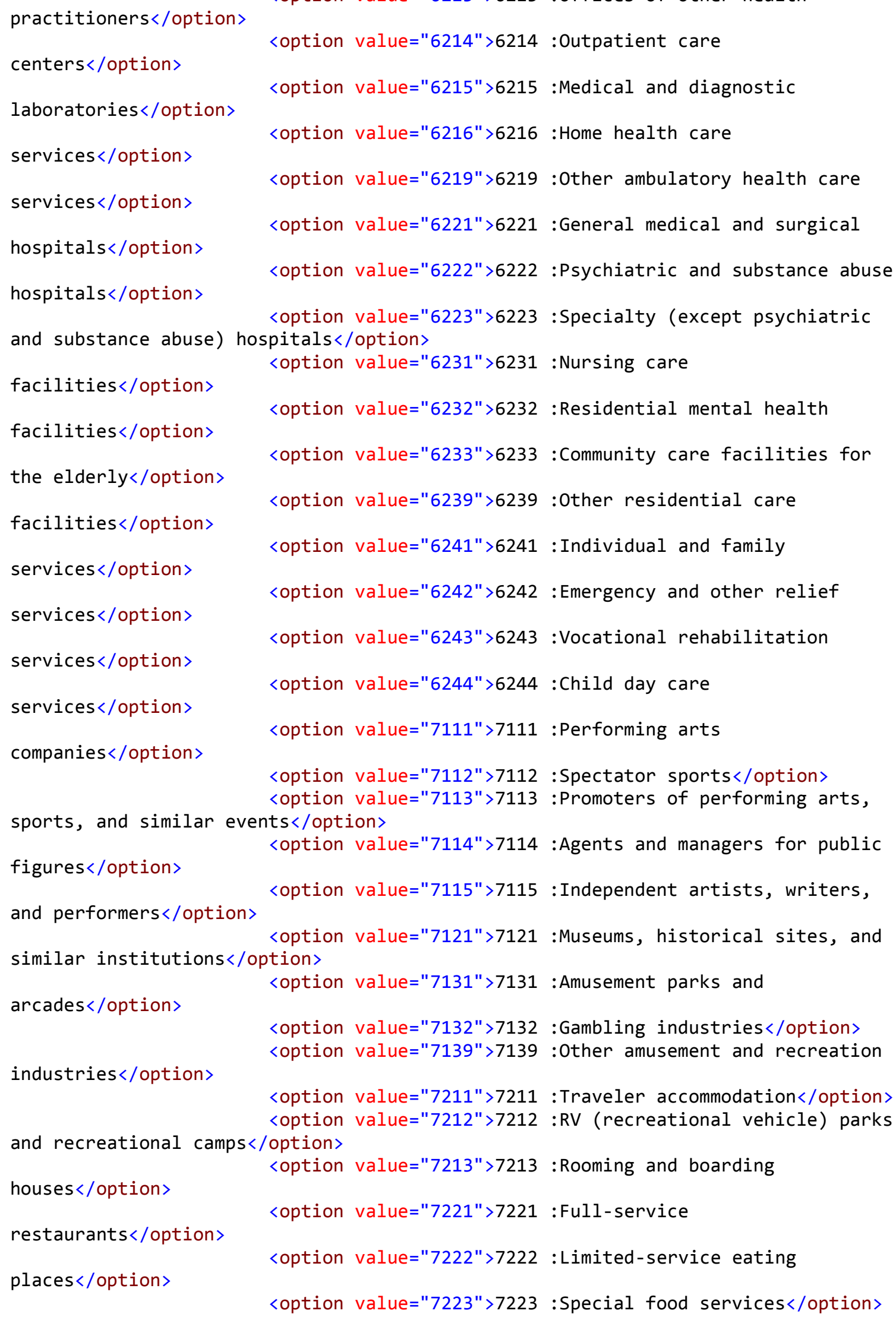




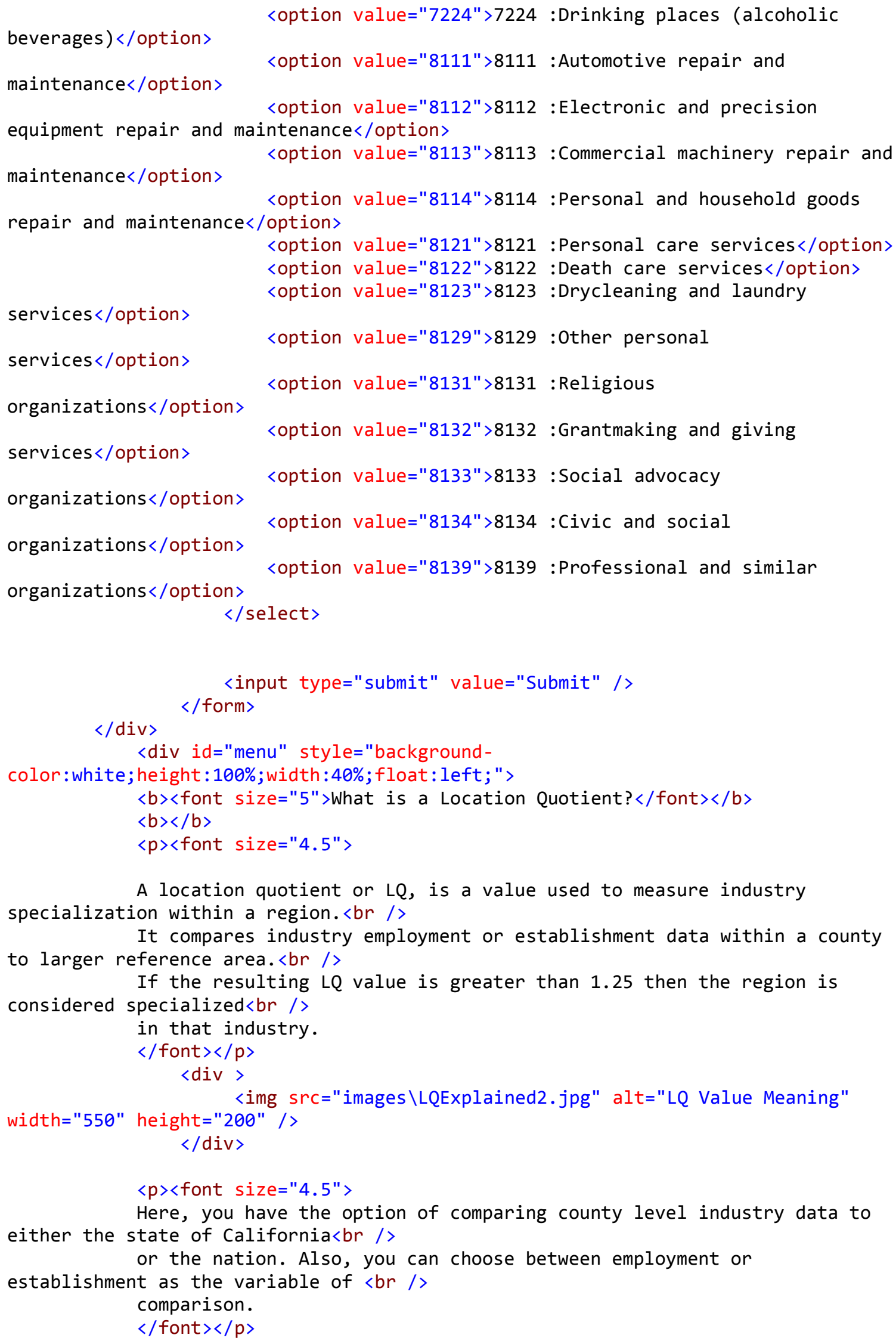

A location quotient or $L Q$, is a value used to measure industry specialization within a region. $\langle b r />$

It compares industry employment or establishment data within a county to larger reference area. $\langle b r />$ 


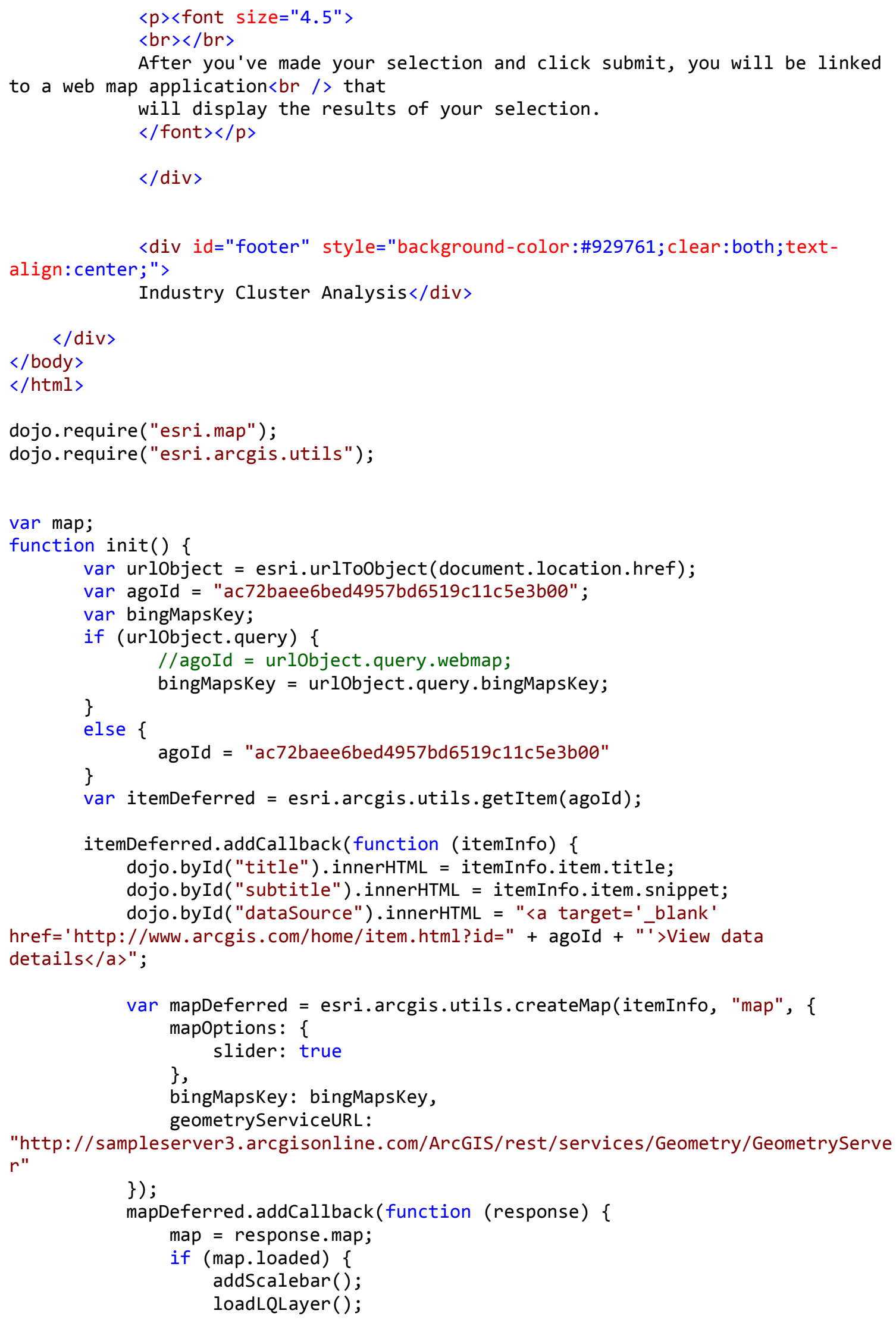




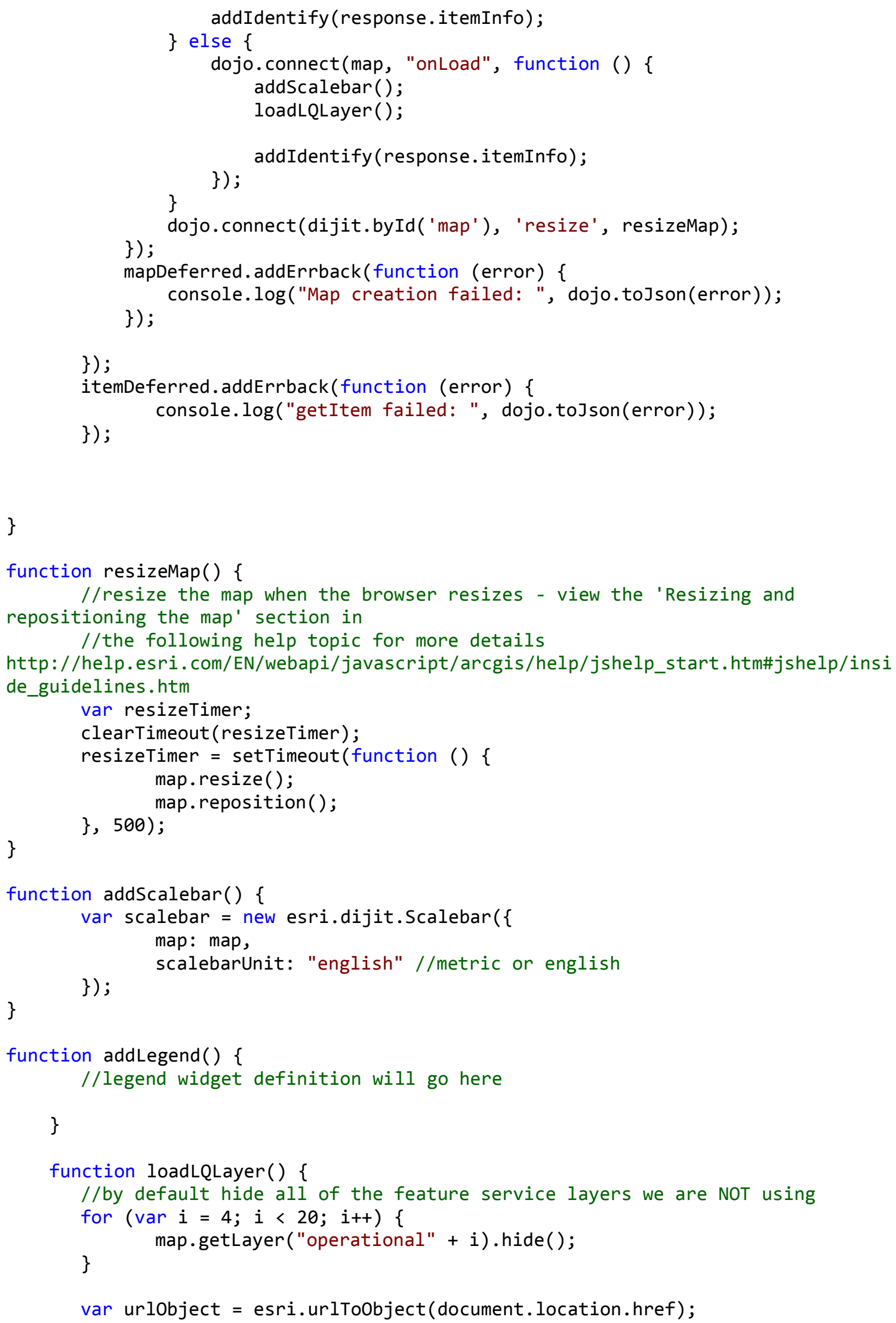


var levelofComparison = urlobject.query.levelofComparison, lqVariable = urlobject.query. lqVariable,

urlobject.query.threeDigitCode, twoDigitCode = urlobject.query.twoDigitCode, threeDigitCode = fourDigitCode = urlobject.query.fourDigitCode;

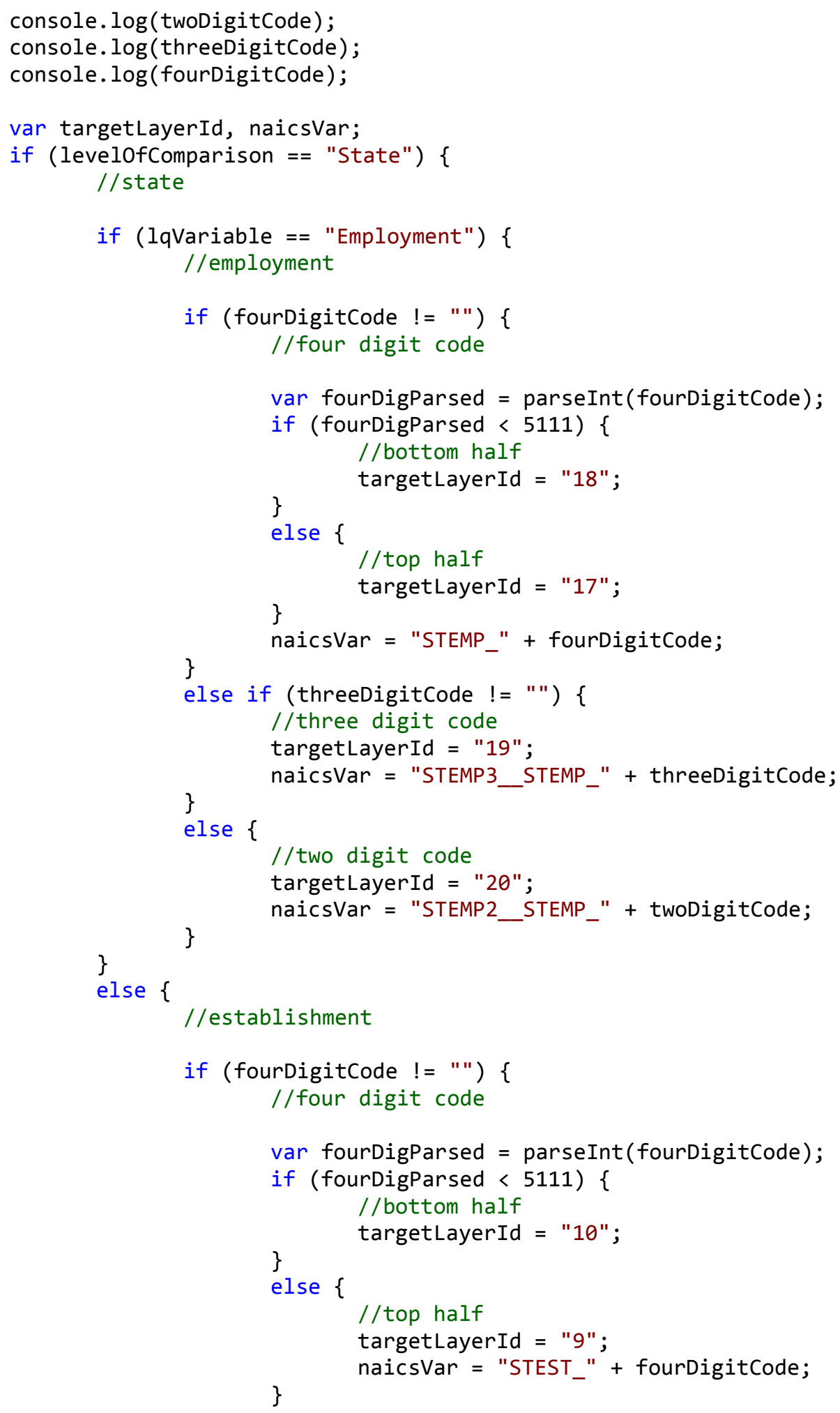




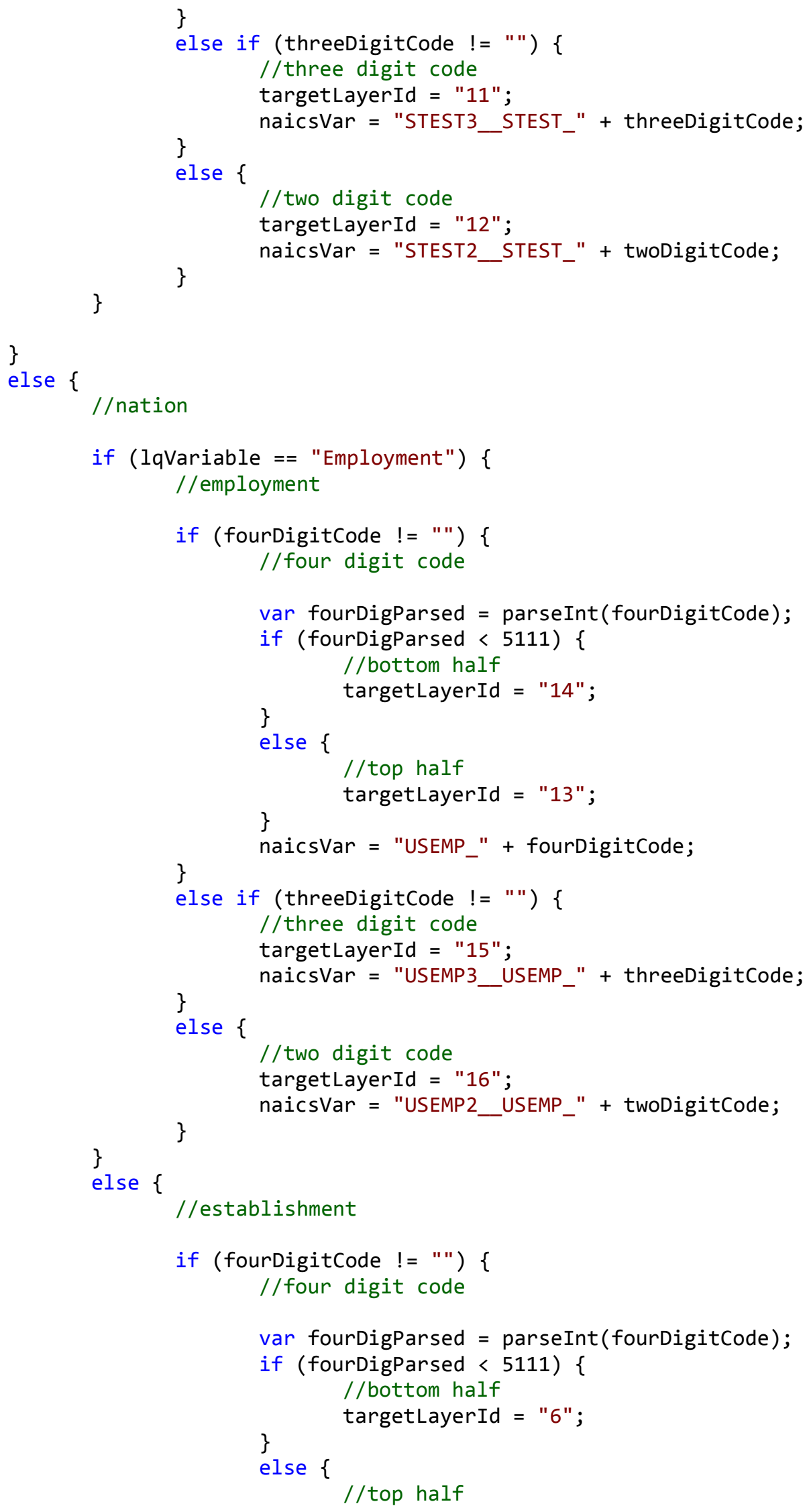




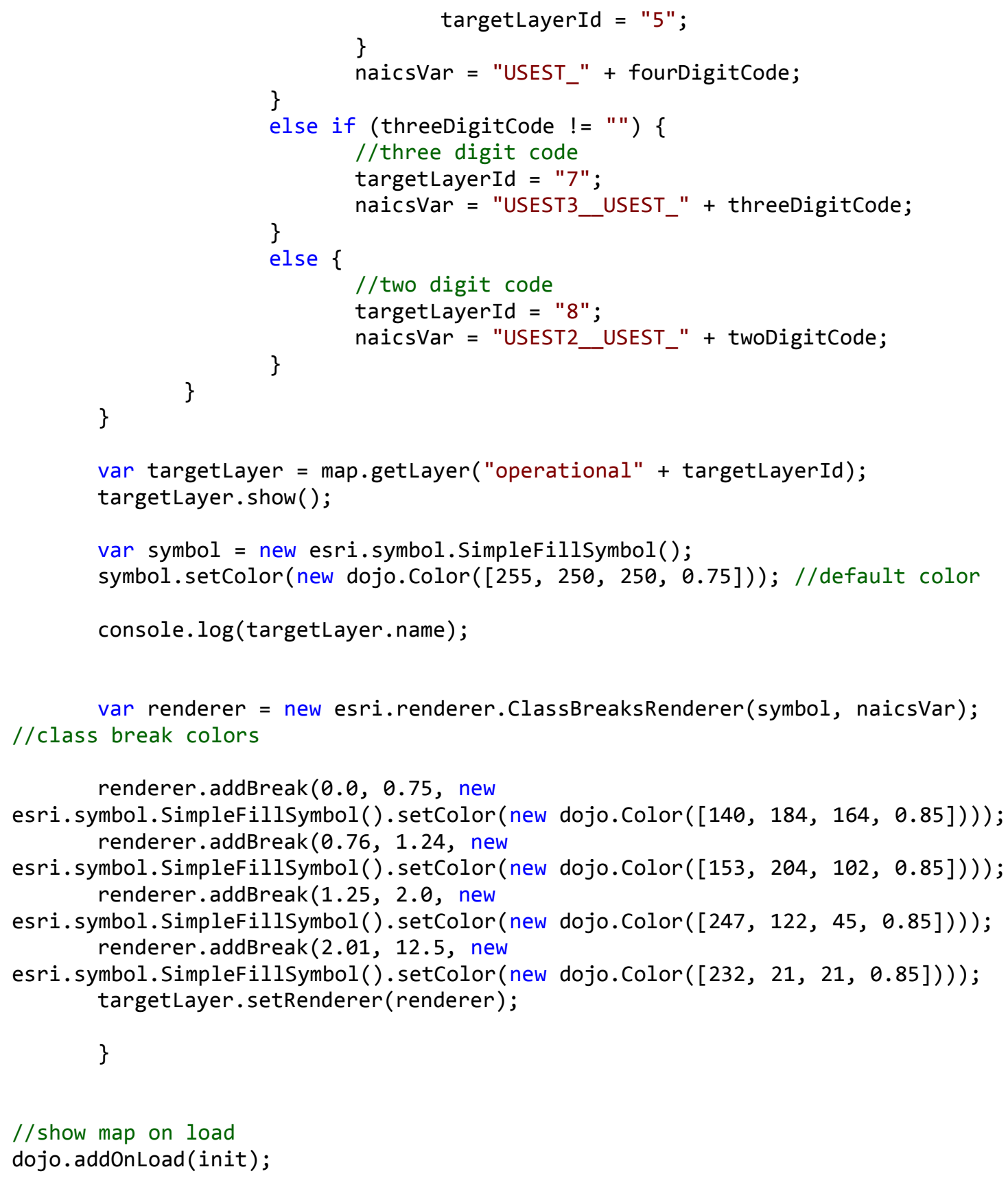

